\title{
VALOR DE EMPRESAS DO SETOR SUCROALCOOLEIRO: UM MODELO DE AVALIAÇÃO
}

\author{
RICARDO DE ASSIS PERINA
}

Engenheiro Agrônomo e Bacharel em Ciências Econômicas

Orientador: Prof. Dr. PEDRO CARVALHO DE MELLO

Dissertação apresentada à Escola Superior de Agricultura "Luiz de Queiroz", Universidade de São Paulo, para obtenção do título de Mestre em Ciências, Área de Concentração: Economia Aplicada.

\author{
PIRACICABA \\ Estado de São Paulo - Brasil \\ Dezembro - 2002
}


Errata

PERINA, R. A. Valor de empresas do setor sucroalcooleiro: um modelo de avaliação.

p. item linha onde se lê leia-se

2 décima quinta Variação Variação Absoluta

5 primeira 1.1 Exportação de açúcar... Exportações por tipo de

$5 \quad 1.1$ décima quinta Evolução das exportações brasileira.

$5 \quad 1.1$ décima sétima U\$/t)

...Kg/hab...

$\begin{array}{lll}6 & 1.1 & \text { sétima } \\ 7 \text { e } 8 & 1.1 & \text { quinta e nona }\end{array}$

Fonte: CEPEA (2002) açúcar...

Evolução das exportações brasileiras de áçúcar.

(U\$/t)

...Kg/hab/ano...

Fonte: Elaborado pelo

autor com dados do

CEPEA (2002)

$\begin{array}{lllll}9 & 1.1 & \text { décima terceira } & \ldots 34,6333 & \ldots 37,2494 \\ 10 & 1.1 & \text { décima oitava } & \ldots \text {..tabela } 6 \ldots & \ldots \text {..tabela } 7 \ldots \\ 11 & 1.2 & \text { vigésima segunda } & \ldots \text {...Souza }(2000) \ldots & \ldots \text {...Souza e Burnquist } \\ & & & & (2000) \ldots \\ 17 & 2 & \text { décima } & \ldots \text { valorização... } & \ldots \text {... }\end{array}$

$\begin{array}{lll}18 & 2 & \text { sexta }\end{array}$

"Uma avaliação...FALCINI (1995, p 15)

$22 \quad 2.1$ décima quinta

...isoladamente, e que...

Excluir o parágrafo todo

Martins (2000)...caixa

...encargos dívida...

$\mathrm{R}_{\mathrm{E}} \ldots$

$\mathrm{V}^{\mathrm{L}} \ldots$

$\mathrm{V}_{\mathrm{I}(\mathrm{t})} \ldots$

...equação 33 ...

...produção total...

...7557,09

...5282,18

...sola...

...em num...

...valor capital de giro...

$\begin{array}{lll}99 & 5 & \text { décima segunda } \\ 102 & 5 & \text { primeira } \\ 102 & 5 & \text { sétima }\end{array}$

...moretários...

...emrpresários,...

...alteram taza de câmbio...

1045 décima sexta

...tabela $21 \ldots$

...tabela $22 . .$.

104
104 $\quad \begin{array}{ll}5 & \text { décima sexta } \\ \text { vigésima }\end{array}$

...Otim Nomal Pess ...

...isoladamente; além disso,...

Excluir o parágrafo todo

...encargos da dívida...

$\mathrm{R}_{\mathrm{e}} \ldots$

$\mathrm{V}^{1}$...

$\mathrm{V}_{\mathrm{i}(\mathrm{t}) \cdots}$

...equação 32 ...

...produção total anual...

...7557,09 t

$\ldots . .5282,18 \mathrm{~m}^{3}$

...solo...

...em um...

...valor do capital de

giro...

...monetários...

...empresários...

...alteram a taxa de

câmbio...

...tabela $22 \ldots$

...tabela 23...

... Otimista Normal

Pessimista... 


\section{Dados Internacionais de Catalogação na Publicaçāo (CIP) DIVISĀO DE BIBLIOTECA E DOCUMENTAÇĀO - ESALO/USP}

Perina, Ricardo de Assis

Valor de empresas do setor sucroalcooleiro: um modelo de avaliação / Ricardo de Assis Perina. - - Piracicaba, 2002.

$127 \mathrm{p}$.

Dissertação (mestrado) - - Escola Superior de Agricultura Luiz de Queiroz, 2002. Bibliografia.

1. Economia política 2. Empresas agrícolas (Avaliação) 3. Indústria açucareira (Economia) 4. Indústria agrícola (Economia) 5. Indústria alcooleira (Economia) 6. Mercado aberto 7. Negociação 8. Teoria econômica 9. Valor econômico I. Título

CDD 338.476641

Termitida a copla total ouparcial deste documento desid que citada a fonte 2 o autor 


\section{DEDICATÓRIA}

Aos meus pais "in memorian" .

À Elza, minha esposa e incentivadora.

Aos meus filhos José Ricardo, Mariana e Ana Luísa.

Que Deus permita que estes anos estudos sejam exemplo positivo para o resto de nossas vidas. 


\section{AGRADECIMENTOS}

Aos professores da ESALQ, representados na pessoa do Carlos Bacha, que acreditaram na minha proposta.

Aos colegas com quem compartilhamos conhecimento e amizade.

Ao Daltro Cella e à Paula Pavarina pelos momentos que estivemos juntos nos estudos, mas principalmente pelas demonstrações de verdadeira amizade .

Ao colega Antônio Ruiz que me incentivou a assumir esta empreitada. Ao Arlélio Leite dos Santos pelo companheirismo e pelo exemplo de determinação. À Sandra e Ana Maria, colaboradoras de todas as horas, sem elas meus caminhos com certeza seriam mais árduos.

A equipe de colaboradores do Departamento de Economia, nas pessoas da Maielli e Ligiana pela paciência e dedicação.

A diretoria e equipe da Usina Benálcool S/A que me proporcionaram acesso aos dados básicos necessários para o trabalho.

Aos professores Alexandre Mendonça de Barros, Márcia de Moraes e Pedro Valentim Marques, pelas contribuições a este trabalho. Ao 
professor Adriano Azevedo Filho por me prestigiar com seus conhecimentos e pela amizade construída durante esse tempo.

Particularmente, ao professor Pedro Mello, que nestes anos privilegiou-me com sua atenção, não se negando a compartilhar seu amplo espectro de cultura e conhecimento, dentro e fora das salas de aula. Ser seu orientado muito me envaidece.

A Deus que me deu a vida e uma família maravilhosa, agradeço pela saúde e proteção em todo tempo e lugar desta caminhada. 


\section{SUMÁRIO}

Página

LISTA DE FIGURAS.................................................................. viii

LISTA DE TABELAS ..................................................................... ix

LISTA DE QUADROS .................................................................

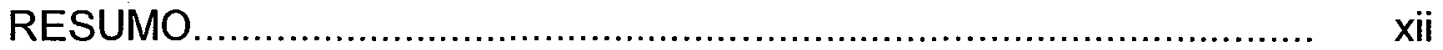

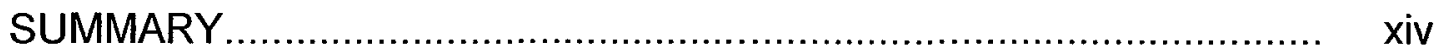

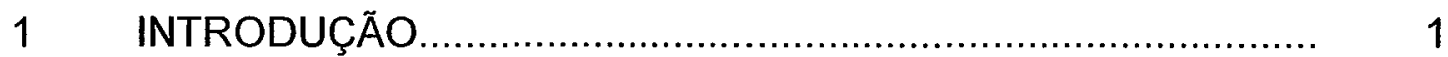

1.1 Aspectos recentes do setor sucroalcooleiro................................ 1

1.2 O mercado livre e os negócios do setor sucroalcooleiro.............. 11

1.3 O que se pretende com esse trabalho..................................... 14

2 MÉTODOS DE DETERMINAÇÃO DO VALOR DA

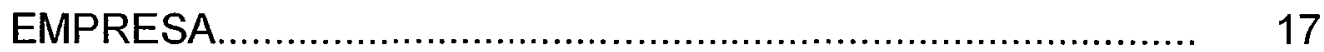

2.1 Método de Valor Contábil........................................................ 21

2.2 Método de Valor de Reposição ou Reconstituição...................... 22

$2.3 \quad$ Método do valor de mercado....................................................... 23

$2.4 \quad$ Método de Valor Presente ........................................................ 24

2.4.1 Custo do capital .......................................................... 30

2.4.2 Período de projeção................................................................ 33

3 TEORIA DA AVALIAÇÃO ECONÔMICA.................................. 36

4 UM MODELO PARA DETERMINAÇÃO DO VALOR DA

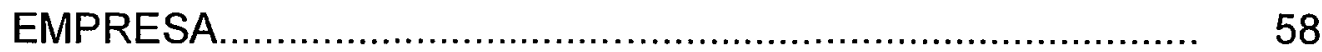

$4.1 \quad$ A empresa agrícola.......................................................... 58 
4.1.1 Composição do preço da cana-de-açúcar................................. 59

4.1.2 Dados para planejamento agrícola.......................................... 68

4.1.3 Dimensionamento de máquinas e equipamentos agrícola.......... 74

4.1.4 Dados técnicos e econômicos................................................... 75

4.1.5 Custos fixos agrícola................................................................... 76

4.1.6 Custos variáveis agrícola........................................................ 79

4.1.7 Avaliação da empresa agrícola................................................ 80

4.1.8 Reposição máquinas........................................................... 84

4.2 Empresa industrial............................................................ 84

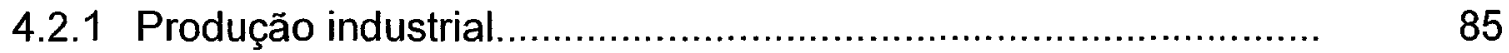

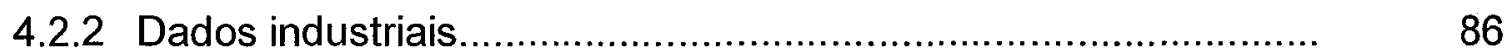

4.2.3 Demonstrativo de recebimentos e desembolsos......................... 87

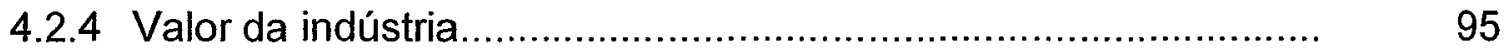

4.2.5 Projeção de desempenho.......................................................... 96

4.2.6 Estimação do custo capital................................................. 96

4.2.7 Estimação valor perpétuo........................................................... 97

$5 \quad$ RESULTADOS E DISCUSSÃO............................................ 98

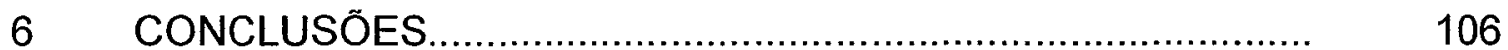

Anexo: COLETÂNEA DE PLANILHAS QUE COMPÕE O MODELO DE AVALIAÇÃO DE EMPRESAS ............................................ 108

REFERÊNCIAS BIBLIOGRÁFICAS............................................ 123 


\section{LISTA DE FIGURAS}

Página

1 Evolução das exportações de açúcar 2001-2002 ........................... 06

2 Indicadores de preços do açúcar mercado interno no período de $1997-2002$ (sc 50kg)

3 Indicadores dos preços de álcool anidro e álcool hidratado no periodo fev/99-set/02

4 Comportamento do valor presente líquido em relação à taxa de juros

5 Comportamento do valor presente líquido em relação ao horizonte de tempo 


\section{LISTA DE TABELAS}

Página

1 Processamento de cana-de-açúcar nas safras de 2000/01

e 2001/02

2 Ranking das dez maiores unidades processadoras de cana na região Centro-Sul em mil toneladas

3 Exportação de açúcar por tipo, (toneladas)

4 Evolução das exportações brasileira

5 Participação das principais distribuidoras no mercado de álcool hidratado.

6 Preços dos produtos da cana-de-açúcar

7 Evolução da produção ( Centro-Sul)

8 Maiores processadores de cana - de - açúcar na região Centro - Sul considerando-se grupos econômicos (2000/01)

9 Equivalência entre quantidade de ATR e produtos. 


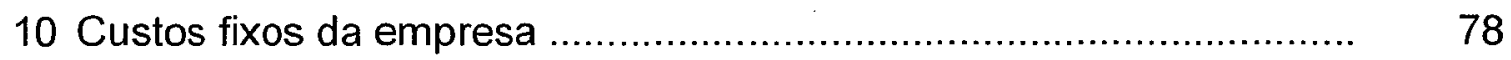

11 Custos variáveis da empresa agrícola............................................... 80

12 Fluxo de caixa líquido da empres agrícola......................................... 84

13 Dados para cálculos de depreciação e seguros................................. 87

14 Demonstrativos de recebimentos e desembolsos.............................. 94

15 Estruturação do fluxo de caixa líquido da empresa industrial ............. 96

16 Indicadores Financeiros no período de Set/99 - Set/02 .................... 97

17 Valor da empresa e taxa de juros................................................... 99

18 Valor da empresa, taxa de juros e horizonte de tempo em $\mathrm{R} \$$ (mil)... 101

19 Valor da empresa e taxa de câmbio

20 Valor da empresa considerando a produtividade de cana-de açúcar otimista

21 Valor da empresa considerando a produtividade agrícola pessimista.. 104

22 Cenários de preços

23 Valor da empresa e preços dos produtos 


\section{LISTA DE QUADROS}

Página

1 Tipos de Açúcar e Álcool ......................................................... 4

2 Principais Transações F\&A no setor sucroalcooleiro ...................... 13

3 Critérios de Avaliação para diversos itens patrimoniais ................. 24

4 Representação esquemática do cálculo do valor presente ............. 25

5 Fluxos de Caixa do ponto de vista da Empresa ........................... 29

6 Fluxos de Caixa Livre do ponto de vista do acionista ..................... 29

7 Visualização do Fluxo de Caixa no horizonte de tempo $n$............... 50

8 Produção da empresa agrícola...................................................... 74

9 Produção da empresa industrial .................................................... 86 


\title{
VALOR DE EMPRESAS DO SETOR SUCROALCOOLEIRO: UM MODELO DE AVALIAÇÃO
}

\author{
Autor: RICARDO DE ASSIS PERINA \\ Orientador: Prof. PEDRO CARVALHO DE MELLO
}

\section{RESUMO}

\begin{abstract}
O processo de desregulamentação do setor sucroalcooleiro na década de 1990, induziu os empresários a buscar alternativas que visam a sobrevivência e o crescimento da firma num ambiente de livre mercado. Fusões e aquisições têm sido uma das soluções de adequação a essa nova realidade. A concretização dos negócios de transferências patrimoniais exige, no entanto, parâmetros econômicos que permitam a determinação do valor da empresa em questão. Este trabalho tem por objetivo a construção de um modelo de determinação desse valor, a partir do estudo e seleção de um método, validado pela teoria econômica e aceito pelo mercado. O método selecionado utiliza o valor presente líquido dos fluxos de caixa projetados num determinado período de tempo, e descontados a uma determinada taxa de juros representativa da classe de risco do setor. A construção do modelo exige o conhecimento de peculiaridades das empresas do setor, que são caracterizadas por um parque industrial com pesados investimentos em ativos fixos, e que dependem de grande quantidade de matéria prima, a cana de açúcar, oriunda de grandes
\end{abstract}


extensões de áreas agrícolas adjacentes ao parque, de maneira a se viabilizar a logistica de transportes. Sugere-se, para efeito de cálculo, a segmentação das empresas em agrícola e industrial, construindo-se fluxos de caixa independentes, onde a empresa agrícola é fornecedora de matéria-prima, e a indústria compradora e processadora. Com os dados obtidos em pesquisa de campo numa unidade considerada padrão, ou seja, com uma determinada capacidade de moagem de cana de açúcar, com um dado mix de produção de açúcar e álcool, e com a utilização de um modelo implementado em software Excel, chega-se aos valores presente líquido dos fluxos de caixa das empresas agrícola e industrial. Deduzindo-se destes valores o valor das dividas líquidas, se obtém o valor líquido da empresa. Considerando-se que o valor da empresa é obtido a partir de valores futuros, e portanto incertos, o modelo permite diversas simulações a partir de cenários que analisam a sensibilidade dos valores à mudanças nos parâmetros técnicos e econômicos. 


\title{
VALUE OF COMPANIES OF THE SUGAR AND ALCOHOL SECTOR: AN EVALUATION MODEL
}

\author{
Author: RICARDO DE ASSIS PERINA \\ Adviser: Prof. PEDRO CARVALHO DE MELLO
}

\section{SUMMARY}

The process of desregulation of the sugar and alcohol sector in the decade of 1990, induced entrepreneurs to search alternatives that aim the firm's survival and growth in an environment of free market. Mergers and acquisitions have been one of the solutions of adequacy to this new reality. The realization of patrimonial transferences' businesses demands, however, economic parameters that allow the determination of the value of the company in question. This work has for objective the construction of a model of this value determination, from the study and election of a method validated for the economic theory and accepted for the market. The selected method uses the liquid present value of cash flows projected in one determined period of time, and discounted to one determined tax of interests that is representative to the risk class of the sector. The models' construction demands the knowledge of the companies peculiarities, which are characterized by an industrial park with heavy investments in fixed assets, and they depend on a great amount of raw 
material, the sugar cane, deriving of great extensions of agricultural areas that are adjacent to the park, to make the transport logistics possible. It is suggested, for calculation effect, the segmentation of the companies in agricultural and industrial companies, making independent cash flows, where the agricultural companies are raw material suppliers, and the industry is the purchaser and processor one. With data from field research and from an unit considered a standard unit, that means, with a determined capacity of sugar cane crushing , with a certain mix of sugar and alcohol production, and with the use of a Model implemented in Excel software, arrives it to the liquid present values of the agricultural and industrial companies cash flows. Deducing of these values the value of liquid debts, it gets the company liquid value. Considering that the company value is gotten from future values, and therefore uncertain values, the model allows a lot of simulations from scenes that analyze the sensitivity of values to changes of technical and economic parameters. 


\section{INTRODUÇÃO}

$\mathrm{Na}$ década dos anos 1990 a economia brasileira passou por significativas transformações, onde a busca da competitividade num mercado globalizado foi a tônica das estratégias das empresas. No setor sucroalcooleiro, com a eliminação do sistema de preços administrados, não tem sido diferente. Após a desregulamentação, o setor passou a atuar num ambiente de livre mercado, o que exige dos administradores novas estratégias que visem não só a sobrevivência como também o crescimento da firma. Entre as diversas alternativas de inserção neste mercado, as empresas têm optado pela sua reestruturação através de aquisições e/ou fusões, resultando nos últimos anos em um significativo número de transferências acionárias. No presente trabalho pretende-se construir um modelo adequado de avaliação de empresas no setor sucroalcooleiro, fornecendo dados que auxiliem a tomada de decisões dos agentes envolvidos nessas negociações.

\subsection{Aspectos recentes do setor sucroalcooleiro}

A indústria sucroalcooleira, de acordo com dados obtidos em Guilhoto et al. (2001), tem expressiva participação na economia brasileira sendo responsável por algo em torno de $3 \%$ do PIB ou $\mathrm{R} \$ 30.216$ milhões em valores de 1999 , representando $11,2 \%$ do movimento dos agronegócios. O setor tem na cana-de-açúcar a sua principal matéria-prima, que é produzida em áreas agrícolas localizadas próximas da unidade de processamento industrial. 
Isso e os pesados investimentos em ativos fixos,máquinas e equipamentos conferem-Ihe uma especificidade, influenciando e condicionando o tamanho ótimo das unidades produtoras, determinando caracteristicas peculiares quanto à configuração da estrutura de produção. Geograficamente,as unidades industriais estão distribuídas principalmente na região centro-sul, nos estados de São Paulo, Paraná, Minas Gerais, Rio de Janeiro, Mato Grosso, Mato Grosso do Sul e Goiás. Na tabela 1 pode-se verificar que em média, cada unidade processou 1.118 mil toneladas na safra 2001/02. O complexo industrial nesta região está representado por 217 unidades que processaram 242.610 mil toneladas na safra 2001/02. Verifica-se que a quantidade processada pelas 50 maiores unidades teve um acréscimo de 9.333 toneladas o que no entanto, representou uma diminuição proporcional ao total industrializado, passando de $51.75 \%$ para $48,00 \%$.

Tabela 1. Processamento de cana-de-açúcar nas safras de 2000/01 e 2001/02.

\begin{tabular}{lccc}
\hline & Safra 00/01 & Safra 1/2 & Variação \\
\hline Processamento (1000t) & 207.069 & 242.610 & 35541 \\
Total de unidade & 220 & 217 & 3 \\
Média de processamento (1000t) & 941 & 1118 & 177 \\
Processamento das 50 maiores & 107.166 & 116.499 & 9333 \\
Participação das 50 maiores & $51,75 \%$ & $48,00 \%$ & 3,75 \\
\hline
\end{tabular}

Fonte: União das Destilarias do Oeste Paulista - UDOP (2002)

Na safra 2001/02 com dados obtidos no site da UDOP - União das Destilarias do Oeste Paulista (2002), a partir do "ranking" de produção nas principais unidades processadoras, mostrada parcialmente na tabela 2 , calcula- 
se os índices de concentração ${ }^{1} \mathrm{C}_{4}$ e $\mathrm{C}_{8}$, conforme metodologia utilizada por Marques (1992), respectivamente $9,05 \%$ e $15,56 \%$.

Tabela 2. Ranking das dez maiores unidades processadoras de cana na região Centro-Sul em toneladas.

\begin{tabular}{|c|c|c|c|c|c|}
\hline \multicolumn{3}{|c|}{ Safra $00 / 01$} & \multicolumn{3}{|c|}{ Safra $01 / 02$} \\
\hline Ranking & Um.Processadora & Cana & Ranking & Un. Processadora & Cana \\
\hline 1 & São Martinho & 5313581 & 1 & Da Barra (SP) & 5821092 \\
\hline 2 & Santa Elisa & 5074654 & 2 & Santa Elisa (SP) & 5637141 \\
\hline 3 & Da Barra & 4930166 & 3 & Itamarati (SP) & 5270109 \\
\hline 4 & Bonfim & 3981008 & 4 & São Martinho (SP) & 5239159 \\
\hline 5 & Vale do Rosário & 3822169 & 5 & Vale do Rosário (SP) & 4054867 \\
\hline 6 & Itamarati & 3677914 & 6 & Bonfim (SP) & 3957066 \\
\hline 7 & S. João - Araras & 3247780 & 7 & Barra Grande (SP) & 3947349 \\
\hline 8 & S.José - Macatuba & 3167860 & 8 & S. José - Macatuba & 3824873 \\
\hline 9 & Barra Grande & 3086609 & 9 & Nova América (SP) & 3642812 \\
\hline 10 & Nova América & 2846447 & 10 & S. João - Araras (SP) & 3253493 \\
\hline
\end{tabular}

Fonte: UDOP (2002)

O setor tem no açúcar e no álcool seus principais produtos, ofertando ainda subprodutos tais como, melaço, torta de filtro para fertilização, levedura para produção animal, bagaço para fins energéticos, óleo fúsel, vinhaça para fertirrigação, além de energia elétrica gerada a partir do bagaço. Novos produtos buscando diferenciação são ofertados visando-se a agregação de valores. Assim, álcool gel, açúcar orgânico, new sugar (desenvolvido pela usina da Barra) e outros aparecem como novas alternativas de mercado. $O$ quadro 1 relaciona os principais tipos de açúcar e álcool comercializados pelo setor.

$$
\begin{gathered}
C_{4}=\sum_{i=1}^{4} Q_{t} / \sum_{t=1}^{n} Q_{t} \text {, Sendo } \mathrm{Q}=\text { Quantidade matéria prima processada, } \mathrm{i}=\text { unidades industriais , } \mathrm{e} \\
\mathrm{n}=\text { número de unidades. }
\end{gathered}
$$




\begin{tabular}{|c|c|c|c|}
\hline \multicolumn{2}{|c|}{ Tipos de Açúcar } & \multicolumn{2}{|c|}{ Tipos de Álcool } \\
\hline Grupos & Subgrupos & Grupos & Subgrupos \\
\hline Açúcar Refinado & $\begin{array}{l}\text { Amorfo } \\
\text { Glaçúcar } \\
\text { Granulado }\end{array}$ & \multirow{2}{*}{ Álcool anido } & \multirow{2}{*}{$\begin{array}{l}\text { Combustivel e } \\
\text { outros fins }\end{array}$} \\
\hline Açúcar Líquido & $\begin{array}{l}\text { Xarope invertido } \\
\text { Xarope simples }\end{array}$ & & \\
\hline \multicolumn{2}{|l|}{ Açúcar Orgânico } & \multirow{3}{*}{ Álcool Hidratado } & \multirow{3}{*}{$\begin{array}{l}\text { Combustivel e outros } \\
\text { fins }\end{array}$} \\
\hline Açúcar Demerara & & & \\
\hline \multicolumn{2}{|c|}{ Açúcar GC (granulometria controlada) } & & \\
\hline Açúcar Cristal & $\begin{array}{l}\text { Cristal standard } \\
\text { Cristal superior } \\
\text { Cristal especial }\end{array}$ & Álcool gel & \\
\hline
\end{tabular}

Quadro 1 - Tipos de açúcar e álcool.

Fonte: União da Agroindústria Brasileira - Unica (2002)

Grande parte da produção do açúcar, $53 \%$ conforme a FNP (2001), destina-se ao setor externo. Segundo Moraes (2000) as exportações brasileiras cresceram 18,8\% a.a. no período de 1988 a 1998, sendo o Brasil o maior exportador mundial. Entre as diversas razões que levaram o país a aumentar sua participação no mercado externo, têm-se os baixos níveis de preços internos ocorridos na década de 1990, assim como fácil acesso ao crédito vinculado à exportações futuras, através dos ACC ou pré-pagamento contra garantias. Os preços têm como referências a bolsa de Nova York (NYBOT), nos tipos VHP ou "Raw" (demerara). O refinado e cristal são referenciados na Bolsa de Mercado de Futuros em Londres (LIFFE). A tabela 3 mostra a distribuição dos principais tipo de açúcares exportados, sendo o principal deles o açúcar VHP representando em 2001 cerca de $60 \%$ do volume exportado. 
Tabela 3. Exportação de açúcar (toneladas).

\begin{tabular}{lrr}
\hline Açúcar & 2000 & 2001 \\
\hline Refinado & 400.600 & 604.500 \\
Cristal & 1.299 .014 & 1.961 .945 \\
Demerara & 1.018 .798 & 1.820 .890 \\
VHP & 3.778 .569 & 6.341 .778 \\
Total & 6.496 .981 & 10.729 .113
\end{tabular}

Fonte: UDOP (2002)

Analisando-se dados da DATAGRO apud ALCOPAR (2002), verifica-se que o volume de exportações de açúcar se mantêm com tendência crescente, embora no ano de $2000 \mathrm{com}$ a queda de safra tenha havido uma redução no volume exportado. Para 2002 estima-se algo em torno de 12 milhões de toneladas. A Tabela 4 mostra a quantidade exportada, o valor das exportações em dólares, bem como o preço médio ponderado.

Tabela 4. Evolução das exportações brasileira.

\begin{tabular}{cccc}
\hline Ano & Mil toneladas & U\$ milhões & $\begin{array}{c}\text { Preço Médio } \\
\text { U\$/t })\end{array}$ \\
\hline 1997 & 6377 & 1771,32 & 277,75 \\
1998 & 8372 & 1940,84 & 231,81 \\
1999 & 12124 & 1909,75 & 157,52 \\
2000 & 6506 & 1199,11 & 184,30 \\
2001 & 11173 & 2279,06 & 203,98 \\
\hline
\end{tabular}

Fonte: DATAGRO citado por ALCOPAR (2002)

Os preços do açúcar mercado externo,em dolares por tonelada, segundo a ALCOPAR (2002) com dados da DATAGRO, nos anos 2000 e 
2001 variaram no intervalo de $\mathrm{U} \$ 148,94$ à $\mathrm{U} \$ 226,84$ podendo ser visualizados na figura 1.

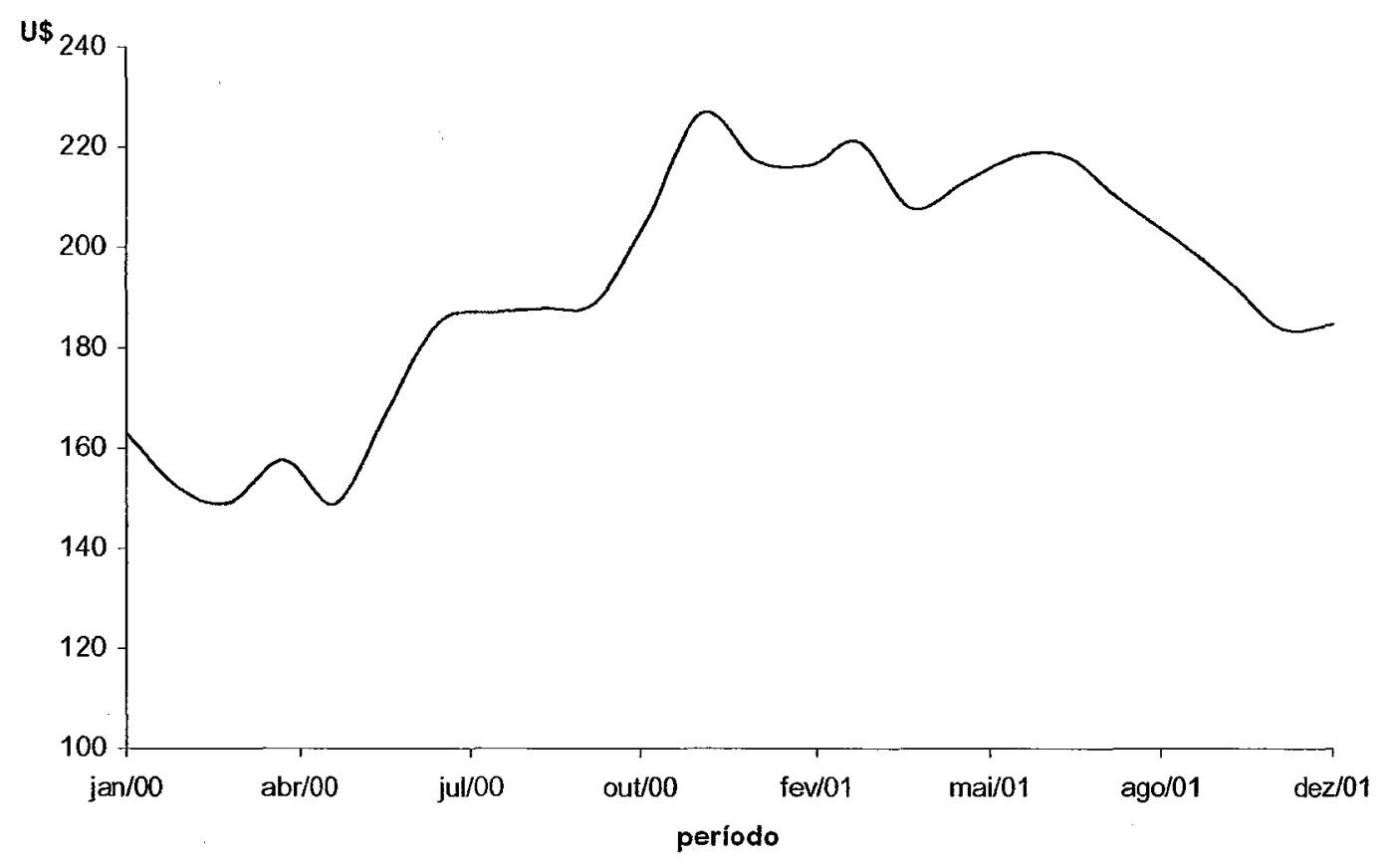

Figura 1 - Evolução dos preços das exportações de açúcar 2000 à 2001. Fonte: Base de dados ALCOPAR (2002)

No mercado interno, o crescimento da demanda é estimada pela Única (2002) em $2 \%$ a.a., depende basicamente do consumo da indústria de alimentos. O consumo per capita está em $56,2 \mathrm{~kg} / \mathrm{hab}$ segundo a empresa LMC (2002).

Os preços do açúcar no mercado interno, em moeda nacional, segundo dados do indicador do CEPEA-ESALQ(2002) variaram entre $\mathrm{R} \$ 13,80$ à $\mathrm{R} \$ 30,33$, a saca de $50 \mathrm{~kg}$, no período de maio/1997 à outubro/2002. A figura 2 ilustra as variações de preços ocorridas no período. 
Essas variações dependem dos preços externos como também do volume de safra e época do ano.

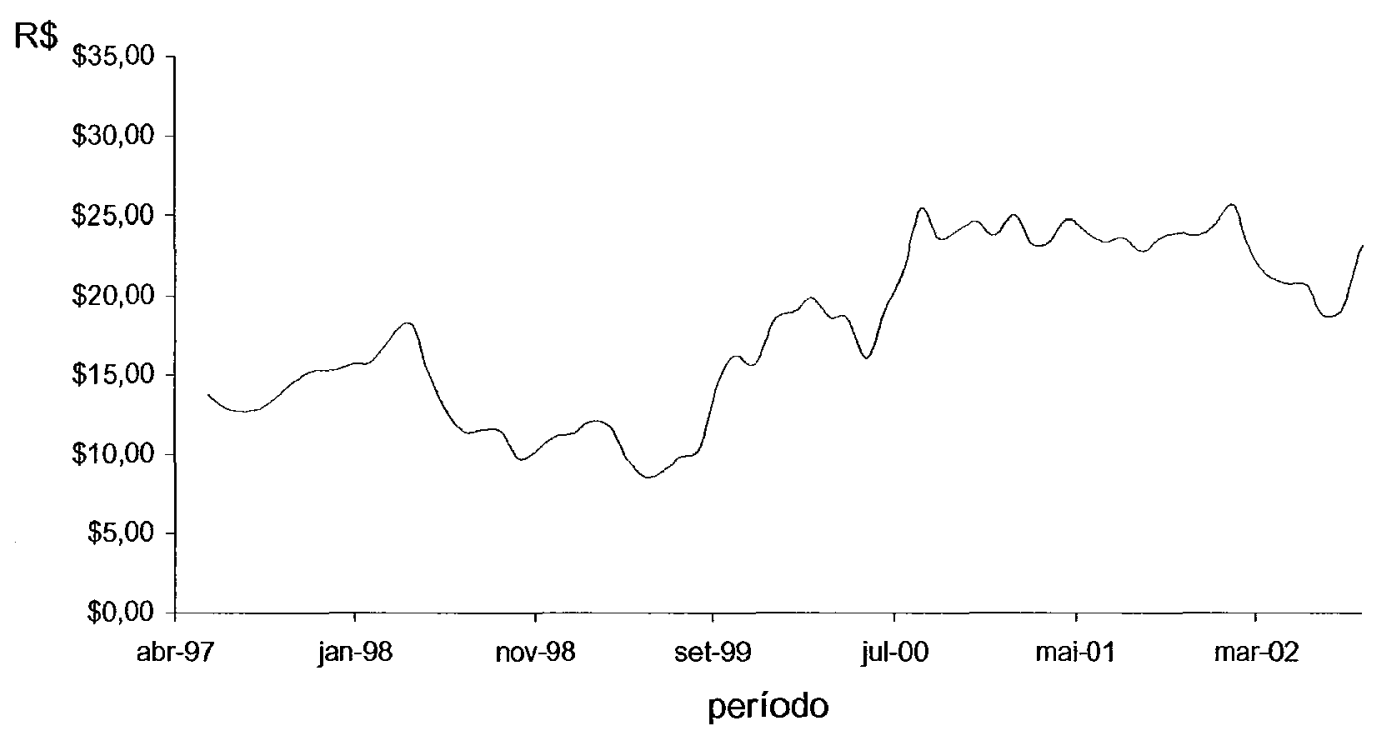

Figura 2 - Indicadores de preços do açúcar no mercado interno no período de $1997-2002$ / (sc 50kg).

Fonte: Centro de Estudos e Pesquisas em Economia Aplicada - CEPEA (2002)

O álcool anidro e hidratado destinam-se, principalmente ao mercado interno, compondo a matriz energética do país. O álcool anidro tem sido adicionado à gasolina em proporção que varia de acordo com a política governamental de abastecimento de combustível.

Os dados plotados na figura 3 ilustram uma correlação positiva existente entre os preços do álcool anidro e do álcool hidratado. Tem-se observado que a produção de álcool anidro, considerando-se os valores de equivalência do ATR , utilizado para sua produção, tem melhor remuneração que a do álcool hidratado. Isso é facilmente explicado pela queda no consumo deste, em razão da obsolescência da frota movida exclusivamente à álcool. 
Comparativamente, a produção de açúcar tanto para o mercado interno como externo tem tido melhor remuneração que a do álcool, conforme MarjottaMaistro (2002). No estudo de Costa (2000), verifica-se influência dos preços do açúcar e do álcool anidro nos preços do álcool hidratado. Assim os empresários têm direcionado novos investimentos, em usinas de açúcar e mesmo em colunas de destilação do álcool anidro.

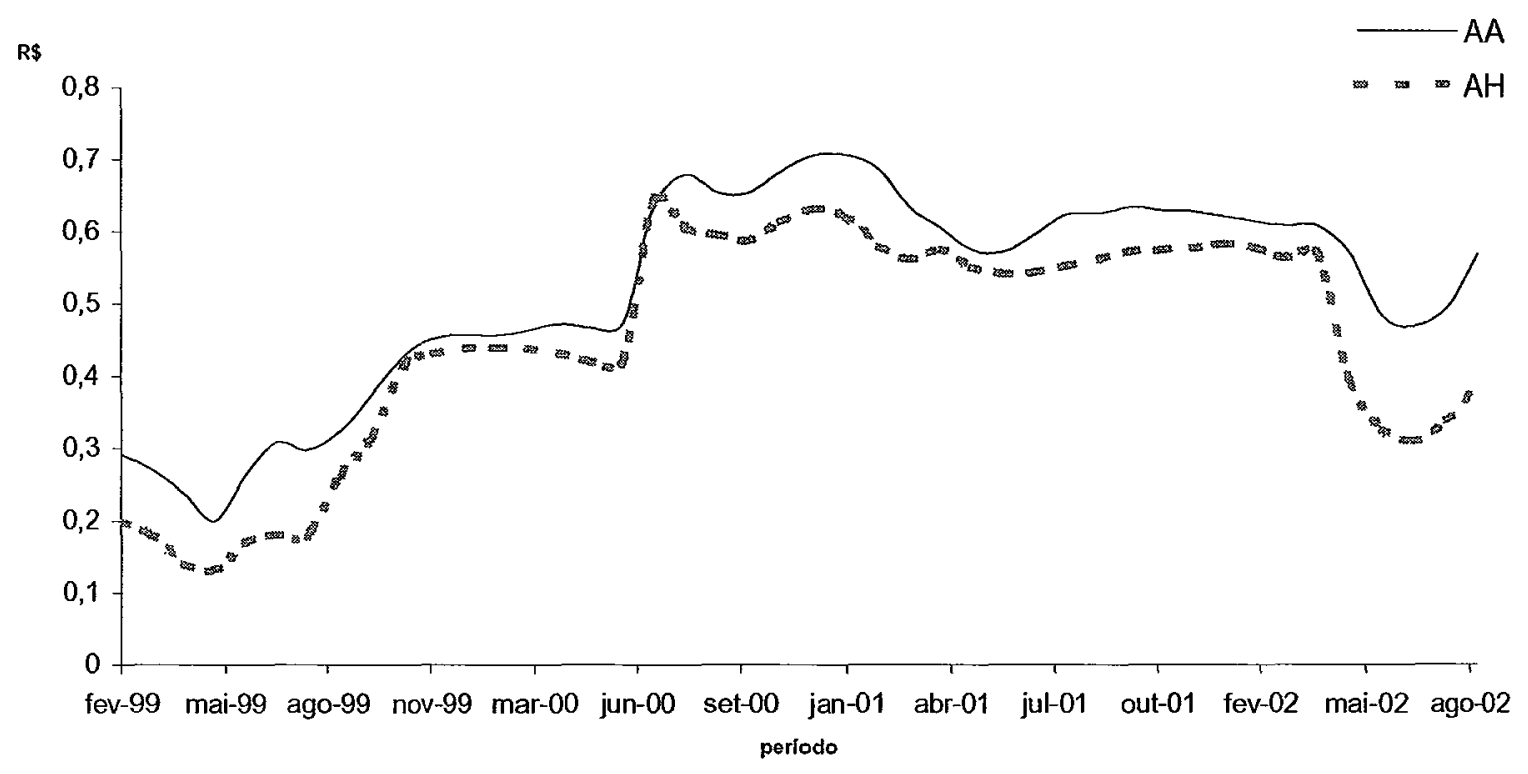

Figura 3 - Indicadores de preços de álcool anidro e álcool hidratado no período de fevereiro de 1999 à setembro de 2002.

Fonte: CEPEA (2002)

Segundo a ANP (2002), no ano 2001 a comercialização nacional de álcool etílico hidratado foi realizada por 165 distribuidoras. O índice de concentração $\mathrm{C}_{4}$ totalizou $40,07 \%$ e o índice $\mathrm{C}_{8} 60,35 \%$, mostrando alto grau de concentração deste mercado distribuidor. A tabela 6 mostra a participação das principais distribuidoras no mercado de álcool hidratado. 
Tabela 5. Participação das principais distribuidoras no mercado de álcool hidratado.

\begin{tabular}{lc}
\hline Distribuidora & Participação \% \\
\hline BR & 13,3047 \\
Ipiranga & 10,5752 \\
Esso & 8,4339 \\
Shell & 7,7549 \\
Texaco & 6,7239 \\
Acelub & 6,1065 \\
Maçom & 4,4540 \\
Petrosul & 2,9956 \\
Petro-Garças & 2,4019 \\
Outras & 34,6333 \\
\hline
\end{tabular}

Fonte: ANP (2002)

Numa análise conjuntural no ano de 2002, segundo o CONSECANA, os preços do açúcar mantiveram-se com tendência estável e mesmo crescente indicando que as unidades industriais nesta safra, direcionariam o máximo de matéria-prima para a fabricação de açúcar, utilizando-se de sua capacidade plena. Os preços do álcool anidro e do hidratado, por outro lado, com o aumento da oferta em maio e junho aliado a uma expectativa de maior produção de cana na safra 2002/03 tiveram declínio nos preços que recuperaram-se apenas a partir do mês de agosto . A tabela 6 mostra os valores médios dos produtos no Estado de São Paulo. Conforme o CEPEA ( 2002 ) os preços do açúcar em outubro de 2002 atingiram $\mathrm{R} \$ 40,00$ a saca de $50 \mathrm{~kg}$. 
Tabela 6. Preços dos produtos da cana-de-açúcar.

\begin{tabular}{lccccccc}
\hline \multicolumn{1}{c}{ Mês } & AMI & AME-Bco & AME-VHP & AAC & AHC & AAI & AHI \\
Maio & 20,69 & 15,79 & 14,19 & 570,78 & 491,07 & 577,65 & 505,76 \\
Junho & 18,76 & 17,69 & 15,66 & 483,72 & 406,99 & 522,12 & 422,87 \\
Julho & 19,2 & 18,94 & 15,77 & 469,25 & 387,05 & 455,42 & 392,81 \\
Agosto & 22,95 & 19,88 & 17,85 & 493,71 & 421,57 & 489 & 418,58 \\
Setembro & 24,25 & 22,33 & 20,14 & 569,86 & 484,96 & 568,68 & 490,09 \\
& & & & & & & \\
\hline
\end{tabular}

Fonte: CONSECANA (2002a)

Segundo a DATAGRO apud UDOP (2001), a indústria sucroalcooleira tem crescido quanti e qualitativamente. No período de 1990 à 1998 a produção de cana-de-açúcar cresceu 3,98\% a.a., enquanto a produção de ART (Açúcares Redutores Totais) cresceu 4,83\%. Neste período a produção de açúcar cresceu $10,41 \%$, a de álcool anidro $17,74 \%$, enquanto o álcool hidratado decresceu $2,84 \%$ a.a..

$\mathrm{Na}$ região centro-sul, responsável pelo processamento de praticamente $80 \%$ da matéria-prima, com dados da UDOP (2002), pode-se verificar, conforme tabela 6 , que a produção de cana-de-açúcar, a partir da safra 1993/94, até a safra $2000 / 01$ teve um crescimento ${ }^{2}$ de $3,9 \%$ a.a. A produção de açúcar, neste mesmo período, teve um crescimento de $11,4 \%$ a.a., enquanto a de álcool anidro teve um crescimento de $13,57 \%$ a.a. e o álcool hidratado um decréscimo de $7,18 \%$ a.a. A queda no consumo de álcool hidratado está associado à redução no número de veículos movidos exclusivamente com este produto.

\footnotetext{
${ }^{2}$ Taxa de crescimento calculada conforme Gujarat( 2000); $r=e^{B_{2}}-1$, onde $r=$ taxa de crescimento $B_{2}=$ inclinação do coeficiente de regressão, $e=\exp$.
} 
Tabela 7. Evolução da produção (Centro-Sul).

\begin{tabular}{|c|c|c|c|c|}
\hline Ano & Cana $(t)$ & Açúcar (sc) & Álc.Anidro $\left(\mathrm{m}^{3}\right)$ & Álc.Hid. $\left(m^{3}\right)$ \\
\hline $1993 / 94$ & 184.088 .464 & 7.008 .673 & 2.378 .810 & 7.993 .866 \\
\hline $1994 / 95$ & 196.314 .744 & 8.515 .061 & 2.575 .864 & 8.571 .303 \\
\hline $1995 / 96$ & 203.944 .477 & 9.315 .315 & 2.588 .202 & 8.260 .971 \\
\hline $1996 / 97$ & 231.604 .080 & 10.478 .385 & 3.834 .636 & 8.278 .971 \\
\hline $1997 / 98$ & 249.691 .936 & 11.384 .396 & 4.779 .591 & 8.482 .987 \\
\hline $1998 / 99$ & 269.827 .990 & 15.179 .824 & 4.802 .532 & 7.478 .459 \\
\hline $1999 / 00$ & 263.948 .899 & 16.899 .838 & 5.393 .194 & 6.241 .040 \\
\hline $2000 / 01$ & 207.068 .849 & 12.631 .848 & 4.802 .385 & 4.261 .979 \\
\hline Taxa de crescimento & 3,91 & 11,44 & 13,57 & $-7,18$ \\
\hline
\end{tabular}

Fonte: UDOP (2002)

\subsection{0 mercado livre e os negócios no setor sucroalcooleiro}

Por sua importância, diversos autores têm realizado estudos enfatizando a inserção do setor no contexto do livre mercado, entre eles Moraes (2000) procurando identificar as características das transações e os arranjos contratuais emergentes mais eficientes, e as tendências de reorganização da cadeia produtiva dada a mudança do ambiente institucional.

A atual estrutura de produção sugere busca de alternativas que visem a economia de escala através de fusões e/ou aquisições na indústria, economia de escopo e, diferenciação de produto. A co-geração de energia vem recebendo novos investimentos, sendo que Souza (2000) relata as condições necessárias para viabiliza-los. Em 1999 já haviam 28 unidades industriais do setor cadastrados no MAE - Mercado Atacadista de Energia. 
Visando-se maior competitividade têm-se observado aquisições, fusões e formação de parcerias estratégicas no setor, com finalidades simultâneas ou não de:

a) Economia de escala na comercialização, visando-se ocupar espaços antes dominados por tradings no mercado internacional e aumentar poder de mercado no caso do álcool.

b) Economia de escala através da concentração de ordem administrativa e poder de mercado na compra de insumos.

c) Economia de escopo em casos de co-geração de energia.

d) Vantagens fiscais obtidas na comercialização de produtos em diferentes estados do país.

Para se ter idéia do volume de negócios ocorridos no setor, a partir de 1997 até meados de 2002 foram registradas 30 fusões e/ou aquisições, sendo que 20 delas ocorreram a partir do ano de 2000 coincidindo com a total desregulamentação do mercado, conforme detalhamento mostrado na quadro 2. Pode-se ainda constatar que o maior número de transações ocorreram no Estado de São Paulo, evidenciando também migração de grupos tradicionais da região nordeste para a região centro-sul e de grupos estrangeiros que operam no setor sucroalcooleiro atraídos provavelmente pelas vantagens competitivas desta região, tais como, mercado consumidor, produtividade e economias externas. 


\begin{tabular}{|c|c|c|c|}
\hline Empresa Alvo & Estado & Data & Comprador \\
\hline São Geraldo & São Paulo & Out/97 & Usina Santa Elisa \\
\hline Santo Alexandre & São Paulo & 1997 & Ipiranga \\
\hline Usina Santa Olinda & Mato Grosso do Sul & 1997 & Grupo J.Pessoa \\
\hline Usina Amália/ Usina Sta.Rosa & São Paulo & 1998 & Usina da Pedra \\
\hline Usina Adelaide & São Paulo & Jun/98 & Usina da Barra \\
\hline Açucareira da Serra & São Paulo & Jun/98 & Cosan \\
\hline Usina Diamante & São Paulo & Jun/98 & Cosan \\
\hline Usina Iracema & São Paulo & 1999 & Usina São Martinho \\
\hline Usina Sanagro & São Paulo & 1999 & Grupo J.Pessoa \\
\hline Usina São José & São Paulo & 1999 & Grupo Antonio Farias \\
\hline Usina Rafard & São Paulo & 2000 & Cosan \\
\hline Usina Benalcool & São Paulo & Abr/00 & Grupo J.Pessoa \\
\hline Usina Delta & Minas Gerais & Mai/00 & Grupo Carlos Lyra \\
\hline Usina Criciumal & São Paulo & Set/00 & Coimbra/ Dreyfus \\
\hline Usina Ipaussu S/A Açúcar e & São Paulo & Nov/00 & FBA - Franco Brás.A.A. \\
\hline Destilaria Vale do Rio Turvo & São Paulo & Dez/00 & José Duarte Silveira Barros \\
\hline Alcovale D.Vale Quitério & Mato Grosso do Sul & Jan/01 & Unialco \\
\hline Usina Portobello & Santa Catarina & $\operatorname{Jan} / 01$ & Glencore \\
\hline Usina Alcomira & São Paulo & Fevr/01 & Márcio André Pavan \\
\hline Univalem & São Paulo & Abr/01 & FBA - Franco Brás.A.A. \\
\hline Destilaria Água Limpa & São Paulo & Mai/01 & Grupo Petribu \\
\hline Usina Guarani & São Paulo & Jun/01 & Beghin Say (EBS) \\
\hline Usina Luciânia & Minas Gerais & Ago/01 & Coimbra Dreyfus \\
\hline Usina Santo Antonio & São Paulo & Set/01 & FBA - Franco Brás A.A. \\
\hline Alta Paulista & São Paulo & 2001 & José Luiz P.Ribeiro Barros \\
\hline Açucareira da Serra & São Paulo & 2001 & Cosan \\
\hline Gasa & São Paulo & 2002 & FBA - Franco Brás A.A. \\
\hline Bela Vista & São Paulo & 2002 & Bazan \\
\hline Oeste Paulista & São Paulo & 2002 & Jorge Cavalcante \\
\hline Generalco & São Paulo & 2002 & Aralco \\
\hline
\end{tabular}

Quadro 2 - Principais transações F\&A no setor sucroalcooleiro.

Fontes: Pasin e Neves (2002), Lopes (2002) e pesquisa de campo

No âmbito da comercialização começam a se destacar grupos que se unem objetivando maior poder de barganha, destacando-se além da COPERSUCAR, o grupo COSAN, o Sindicato da Indústria Sucroalcooleira do Mato Grosso do Sul, Grupo J Pessoa, CRYSTALSEV, entre outros. Uma parceria estratégica no Estado do Paraná permitiu a construção de entreposto 
de embarque de açúcar no Porto de Paranaguá , visando-se redução de custos de comercialização.

A Gazeta Mercantil (2001) e Pasin e Neves (2002) mostram na tabela 8, a moagem de cana de açúcar por grupo econômico, com indicação evidente da reestruturação do mercado produtor, caracterizando um modelo com maior grau de concentração, o que não significa necessariamente redução no número de unidades produtoras. Os dados mostram que mesmo com essa re-alocação os valores $\mathrm{C}_{4}$ e $\mathrm{C}_{8}$, respectivamente $17,09 \%$ e $26,07 \%$ não refletem um elevado nivel de concentração mostrando espaço para novos negócios no setor.

Tabela 8. Maiores processadores de cana-de-açúcar na região Centro-Sul considerando-se grupos econômicos (2000/01).

\begin{tabular}{llcclc}
\hline Grupos Econômicos & $\begin{array}{c}\text { Mat.prima } \\
\text { processada } \\
\text { (mil t) }\end{array}$ & $\begin{array}{l}\text { Grupos } \\
\text { Econômicos }\end{array}$ & $\begin{array}{c}\text { Mat.prima } \\
\text { processada } \\
\text { (mil t) }\end{array}$ \\
\hline 1 & Cosan & 12001 & 8 & Pedro Biagi & 4636 \\
2 & Cia. Energética Sta. Elisa & 8511 & 9 & Alto Alegre & 4556 \\
3 & São Martinho & 7463 & 10 & S. João (Araras) & 4305 \\
4 & Zillo Lorenzetti & 7431 & 11 & Vale do Rosário & 4162 \\
5 & Da Barra & 5807 & 12 & Santa Terezinha & 3846 \\
6 & Açucareira Corona & 4747 & 13 & Usinas Itamarati & 3678 \\
7 & Nova América & 4684 & 14 & J.Pessoa & 3662 \\
\hline
\end{tabular}

Fontes: Concentração... (2001), Pasin e Neves (2002)

\subsection{O que se pretende com esse trabalho}

Neste contexto de mudanças, no qual as aquisições e fusões se destacam, surge o problema da determinação do valor da empresa objeto de negociação. Na busca de parâmetros coerentes que diminuam os problemas de assimetria de informações entre as partes negociadoras, torna-se importante o estudo dos diversos métodos de avaliação de empresas e seleção de um 
método adequado que, responda as principais questões relativas à precificação desses ativos.

A prática da determinação do valor da uma empresa pode ser útil então, em situações que requeiram:

a) Estimar o resultado da realização de novos investimentos;

b) Estimar valores de compra e venda, fusões ou parcerias estratégias;

c) Definir metas e monitorar desempenho analisando-se mudanças do valor da empresa.

Deste modo, define-se a seguir os objetivos geral e especificos que nortearão a elaboração do trabalho.

\section{Objetivo Geral}

Este trabalho tem como objetivo geral estimar o Valor Presente de uma empresa do setor sucroalcooleiro, a partir da especificação e levantamento de dados das principais variáveis direcionadoras que influenciam a formação do fluxo de caixa atualizado.

\section{Objetivos Específicos}

Como objetivos específicos pretende-se:

- Analisar os diversos métodos de avaliação econômica; 
- Verificar a consistência desses métodos com a teoria econômica;

- Selecionar o método mais consistente adequando-o ao estudo;

- Elaborar um modelo para aferição do valor para a indústria sucroalcooleira;

- Implementar o modelo em software, de modo simples e que possa ser utilizado e adequado pelo próprios interessados, em situações onde os parâmetros utilizados não representem a realidade daquela Empresa.

\section{Justificativa e metodologia do trabalho}

Embora uma transação de compra e venda ou fusão envolva recursos de expressiva ordem, há pouca disponibilidade de conceitos e informações objetivas que facilitem a determinação de um valor adequado no negócio de empresas do setor sucroalcooleiro.

A partir do referencial teórico de Mondigliani, Miller e M. J. Gordan utilizados em estudos de Millan (1992), Falcini (1995), Copeland et al. (2000), Damodaran (2001), Martins (2001) e Mattos(2001) o trabalho será estruturado em capítulos, sendo que no capítulo 2, pretende-se analisar os diversos métodos de avaliação econômica, para em seguida no capítulo 3, verificar a consistência teórica do método selecionado. Nos capítulos 4 e 5 pretende-se, respectivamente, levantar as informações, estruturar o modelo com uso do software excel, e discutir os resultados obtidos. Para isso utilizar-se-ão informações obtidas em uma empresa do setor sucroalcooleiro, cuja planta representa uma unidade padrão na atual estrutura do setor. 


\section{MÉTODOS DE DETERMINAÇÃO DO VALOR DA EMPRESA}

No presente capítulo, pretende-se verificar os diversos métodos elencados na literatura e que possam ser utilizados para avaliação da empresa.

A pesquisa bibliográfica relata um grande número de métodos que visam determinar o valor de uma empresa. Muitas vezes, com nomenclatura e metodologias diferentes, resultam valores semelhantes.

Martins (2001) afirma que, as diversas alternativas de avaliação não são conflitantes entre si ou substitutivas uma de outras, podendo haver integração entre diversos métodos.

A primeira grande dificuldade na valorização de uma empresa é que ela não é um ente estático, mas acima de tudo depende de seres humanos responsáveis pela criação de uma cultura interna que leve a interação dos diversos fluxos e processos, objetos da atividade da mesma. Isso justifica o fato de que muitas vezes o valor de empresa está acima daquele que é resultado da soma dos deveres e obrigações que compõem o patrimônio líquido.

"Uma avaliação econômica, ao contrário do que possa parecer, não é uma fixação concreta de um preço ou valor específico para um bem, mas é uma estimativa de base, uma tentativa de estabelecer, dentro de uma faixa, 
um valor referencial de tendência, em torno do qual atuarão as forças de mercado; é um ponto de referência muito importante para a análise e compreensão das diversas forças que movimentam e motivam os indivíduos, em economias livres e eficientes, nas suas relações de troca." FALCINI (1995, p 15)

"Uma avaliação econômica, ao contrário do que possa parecer, não é uma fixação concreta de um preço ou valor especifico para um bem, mas é uma estimativa de base, uma tentativa de estabelecer, dentro de uma faixa, um valor referencial de tendência, em torno do qual atuarão as forças de mercado; é um ponto de referência muito importante para a análise e compreensão das diversas forças que movimentam e motivam os indivíduos, em economias livres e eficientes, nas suas relações de troca." FALCINI (1995, p 15)

Esse autor enfatiza dois fatores de importância para uma boa avaliação o que muitas vezes dificulta a obtenção de resultados adequados.

O primeiro é o da utilidade que o empreendimento representa para o indivíduo, que pode ser objetiva ou subjetiva. No que diz respeito à utilidade objetiva de um empreendimento, a avaliação está assentada na realidade dos números e cifras. A utilidade subjetiva, no entanto, pode apresentar-se com valores decorrentes de interesses não só econômicos, mas muitas vezes interesses pessoais, não traduziveis para números realistas.

O segundo fator refere-se a qualidade das informações relevantes sobre a empresa, no que tange às suas políticas e decisões de investimento, financiamento e dividendos, que influirão no resultado futuro do empreendimento. 
Segundo Martins et al. (2001), a avaliação de uma empresa se inicia pelas demonstrações contábeis, que podem ser ajustadas para obter-se o valor econômico da empresa. No entanto, diversas críticas à sua utilização, listadas a seguir, dificultam a aproximação de um valor adequado.

1. Os relatórios contábeis normalmente se baseiam em custos históricos afastados dos valores correntes;

2. Alguns itens, principalmente as contas à receber, estão contabilizados por seu valor futuro, quando o adequado seria o valor presente;

3. O conservadorismo tende a subestimar os valores dos ativos;

4. Existem várias operações relevantes que normalmente não são registradas, tais como: arrendamento mercantil, posições em derivativos, garantias, goodwill etc.

O capital intelectual, por exemplo, não é contemplado no uso dessas demonstrações.

De acordo com Falcini (1995) o valor de um ativo pode ser medido, basicamente, por dois métodos:

a) Estimativa de valor matemático intrínseco que corresponde a uma estimativa do preço possível de uma eventual venda de um bem ou direito no mercado, no estado em que se encontram;

b) Estimativa do valor de rendimentos líquidos descontados ao valor presente a um determinado custo de oportunidade ou custo de capital; 
O segundo método é chamado pelo autor de valor econômico relevante, ou do valor presente líquido. O valor economicamente relevante de um investimento, no enfoque de rendimentos, é uma função do retorno esperado desse investimento e de seu correspondente risco. Uma avaliação devidamente fundamentada norteia o processo de tomada de decisão do investidor em empresa que se revele eficiente através da sua capacidade operacional de gerar rendimentos com menor risco possivel, maximizando assim o seu valor.

O cálculo do valor econômico está associado à presença de incertezas, pois o processo de cálculo do valor presente envolve estimativa de benefícios econômico futuros e, portanto, incerto. A busca de informações neste sentido é fundamental para estimativas de valor econômico racional.

FALCINI (1995, p37) chama atenção para o fato de que "A qualquer ponto do tempo, uma empresa é um conjunto de projetos de investimento em andamento, cada qual num determinado estágio de geração maior ou menor, de fundos de caixa, função de seus ciclos econômicos e de vida".

O autor visualiza a empresa separando-a por atividades econômicas classificando-as como: monetárias, operacionais, investimentos e financiamentos com recursos próprios ou de terceiros. A primeira refere-se a situação de liquidez da empresa. A segunda define a capacidade produtiva e o nivel tecnológico da mesma. Os investimentos são aqueles necessários para manter ou aumentar esta capacidade e a última mostra o grau de alavancagem e sua influência no valor da empresa.

Conforme Clemente (1999), o Valor Final da Empresa é obtido pela soma do Valor Presente Líquido, Valor Residual e Valor dos Créditos ou 
Débitos Fiscais que compõem o Valor Operacional da Empresa. A esse valor soma-se o Valor dos Ativos Não Operacionais, o Valor das Aplicações Financeiras deduzidas do Valor Atual do Endividamento.

Com o uso de técnicas comparativas de mercado, em ativos e passivos contábeis ajustados e desconto de fluxos futuros dos benefícios líquidos Martins et al. (2001) listam os principais métodos de avaliação econômica, expostos a seguir:

\subsection{Método de Valor Contábil}

O modelo de avaliação patrimonial contábil está baseado na soma algébrica dos ativos e passivos exigiveis, mensurados em conformidade com os principios contábeis tradicionais.

Esse modelo pode ser representado pela equação:

$\begin{aligned} & \text { Valor da } \\ & \text { empresa }\end{aligned}=\begin{gathered}\text { Ativos } \\ \text { contábeis }\end{gathered}-\begin{aligned} & \text { Passivos } \\ & \text { exigiveis } \\ & \text { contábeis }\end{aligned}=\begin{gathered}\text { Patrimônio } \\ \text { Líquido }\end{gathered}$

Por ativos contábeis entende-se como a soma dos ativos circulante, realizável à longo prazo e o permanente. No item passivos exigíveis incluem-se o circulante, o exigivel à curto e longo prazo.

Martins et al. (2001), sugerem que os valores apresentados nas peças contábeis devem ser adequados, para melhor representação do valor patrimonial, pelos seus preços passados, presentes ou futuros. O primeiro representa o custo histórico, o segundo o custo corrente e o terceiro o custo de reposição futuro. Esses mesmos valores podem ser representados pelos 
preços de entrada, obtidos nos segmentos de mercado onde a empresa capta recursos, ou pelos valores de saída obtidos nos segmentos do mercado onde a empresa fornece os produtos.

No entanto, este método é suscetível à críticas, sendo que a principal delas está relacionada às distorções resultantes da legislação tributária que utiliza indicadores de correção inflacionária inadequados à realidade das peças contábeis Martins (2000) considera que o método de avaliação patrimonial pode ser utilizado desde que se incluam a inflação e o custo de oportunidade, tratando, pois, o assunto de forma intertemporal.

Martins (2000) considera ainda que, os diversos métodos de avaliação de empresas podem ser utilizados desde que se considerem dois itens de fundamental importância, que é a inflação e o custo de oportunidade, tratando, pois, o assunto de forma intertemporal. $O$ autor conclui que os métodos com base na avaliação contábil, e do valor presente líquido são complementares e não devem ser tratados isoladamente, e que a pesquisa e a prática devem buscar modelos integradores, pois todos os métodos buscam um único objeto que é o caixa.

\subsection{Método de Valor de Reposição ou Reconstituição}

Esse método refere-se ao valor correspondente aos recursos necessários para a aquisição, dentro de condições normais de todos os bens possuídos pela empresa idênticos aos existentes. Tal método, muitas vezes utilizado é criticado, pois uma empresa pode estar melhor localizada com melhores condições de abastecimento e de mão-de-obra e, embora com as mesmas características tecnológicas possui desempenho superior a outra. São, portanto, empresas semelhantes com valores diferentes. Além disso, a construção de uma nova empresa demanda tempo, que pode estar associado a 
um custo de oportunidade intertemporal, não quantificável, que pode viesar o valor obtido.

\subsection{Método do Valor de Mercado}

Um outro método que é utilizado refere-se à aferição do valor de uma empresa, comparando a outros negócios em situações semelhantes que tenham ocorrido recentemente. No entanto, tal critério pode ser utilizado apenas quando o número de negócios similares ocorre em quantidade suficiente que permita utilizar os valores como proxy. Além disso, esse método costuma desconsiderar os benefícios líquidos futuros que a empresa poderia gerar.

Em termos de equação, a avaliação patrimonial pelo mercado pode ser representada pela equação:

Valor da empresa $=$ Ativos ajustados - Passivos ajustados

Esse método pode ser utilizado em diversas situações onde os itens patrimoniais possuam características tangiveis e possam ser quantificados no mercado, como nos exemplos especificados no quadro 3. Nestes casos os ativos e passivos podem ter seus valores contábeis ajustados pelos preços de mercado. 


\begin{tabular}{|l|l|}
\hline Item patrimonial & Critério de avaliação proposto \\
\hline Estoque de matérias-primas & Custo de reposição \\
Estoque de produtos acabados & Valor líquido de realização \\
Contas à receber & Valor presente do recebimento futuro \\
& Ajustado a seu valor de mercado, de \\
Passivo exigivel & acordo com as condições de crédito e \\
& taxas de juros cordadas. \\
\hline
\end{tabular}

Quadro 3 - Critérios de avaliação para diversos itens patrimoniais. Fonte: Martins (2001)

\subsection{Método de Valor Presente}

O quarto método refere-se ao modelo de avaliação econômica que utiliza o fluxo de caixa obtido pela diferença entre os benefícios e despesas previstos de uma entidade, num determinado horizonte de tempo, atualizado no momento presente por uma determinada taxa de desconto, apropriada para este tipo de empresa.

Algebricamente, o valor presente pode ser obtido pela equação abaixo:

$$
V P=\sum_{t=0}^{n} \frac{B t-C t}{(1+r)^{t}}
$$

Onde:

$$
\begin{aligned}
& V P=\text { Valor Presente; } \\
& n=\text { número de períodos projetados; }
\end{aligned}
$$




$$
\begin{aligned}
& t \quad=\text { Periodo; } \\
& B t=\text { Benefícios obtidos no período } \mathrm{t} \\
& C t=\text { Desembolsos realizados no período } \mathrm{t} \\
& r \quad=\text { Taxa de desconto apropriada a empresa. }
\end{aligned}
$$

O cálculo do valor presente pode ser representado esquematicamente no quadro 4 , onde se obtém os fluxos de caixa nos diversos períodos, por uma determinada taxa de desconto .

\begin{tabular}{|cccc|}
\hline Ano & FC & $\begin{array}{c}\text { Fator de desconto } \\
(\mathrm{f})\end{array}$ & $\begin{array}{c}\text { Valor presente } \\
\text { FC }\end{array}$ \\
\hline 0 & $-F C 0$ & 1 & $-F C 0$ \\
1 & $F C 1$ & $\frac{1}{(1+r)}$ & $F C 1 * f 1$ \\
2 & $F C 2$ & $\frac{1}{(1+r)^{2}}$ & $F C 2 * f 2$ \\
$\vdots$ & $\vdots$ & $\vdots$ & $\vdots$ \\
$\mathrm{N}$ & $F C n$ & $\frac{1}{(1+r)^{n}}$ & $F C n^{*} f n$ \\
\hline
\end{tabular}

Quadro 4 - Representação esquemática do cálculo do valor presente. Fonte: Elaboração do autor, adaptado de Falcini (1995)

Assim, a partir desta disposição analítica, o Valor Presente da Empresa pode ser representado pela equação:

$$
\mathrm{VP}=-\mathrm{FC}_{0}+\sum_{t=1}^{n} \mathrm{FCt} . f t
$$

Onde: 
$V P=$ Valor Presente dos Fluxos de Caixa obtidos num horizonte de tempo n;

$F C_{0}=$ Fluxo de Caixa no periodo zero,referindo-se a desembolsos iniciais para adequação da capacidade produtiva correspondente ao programa de produção proposto;

$F C t=$ Fluxo de Caixa obtido no período $t$;

$F C n=$ Fluxo de Caixa no último periodo projetado;

$f t=$ Fator de desconto no período $t$;

$f n=$ Fator de desconto no periodo $n$;

$t \quad=$ periodo de tempo.

Para Copeland (2000) e Damodaran (2001) e Martins(2001) com o Método do Fluxo de Caixa Descontado (FCD) pode-se obter o valor da empresa por três caminhos. O primeiro descontando-se o fluxo de caixa do ponto de vista da empresa sem considerar os encargos das dívidas ou novos financiamentos. O segundo, como alternativa deste, desconta-se este fluxo de caixa a uma taxa apropriada ao risco desta empresa somando-o ao resultado atualizado das dividas acrescidas dos seus respectivos encargos. No terceiro desconta-se o fluxo de caixa do ponto de vista do acionista, que é obtido deduzindo-se do fluxo de caixa do ponto de vista da empresa o valor das dividas os seus encargos, e acrescentando-se os novos financiamentos necessários para manter o nível de alavancagem adequado a empresa. O fluxo de caixa do ponto de vista da empresa quando esta não possui dividas coincide com o fluxo de caixa do ponto de vista do acionista.

Tecnicamente, o fluxo de caixa do ponto de vista da empresa é igual ao seu resultado operacional depois dos impostos, mais custos que não envolvem desembolso de caixa, menos investimento em capital de giro e capital fixo. Ele não incorpora os fluxos de caixas relativos a despesas de financiamento e ou dividendos. Reflete, pois o caixa gerado pelas operações 
que está disponível a todas as fontes de capital da empresa, tanto na forma de capital próprio como de terceiros. Assim, pode-se expressar algebricamente pela equação:

$$
F C=(R T-C T-D T)(1-t c)+D t+\Delta\left(C G_{t}+I t\right)
$$

Onde:

$$
\begin{aligned}
& R T=\text { Receita no período } \mathrm{t} ; \\
& C T=\text { Despesas desembolsáveis em } \mathrm{t} ; \\
& D T=\text { Despesas não desembolsáveis em } \mathrm{t} ; \\
& t c=\text { Alíquota de impostos; } \\
& \mathrm{t}=\text { Período de tempo; } \\
& \Delta C G_{t}=\text { Variação de capital de giro em } \mathrm{t} ; \\
& \Delta I t=\text { Variação de capital fixo em } \mathrm{t} ;
\end{aligned}
$$

O fluxo de caixa neste caso, representa o potencial de geração de riqueza dos ativos, independente da sua forma de financiamento, já deduzidas as parcelas destinadas a novos investimentos e variação no capital de giro. Chega-se ao valor da empresa caso ela fosse financiada por capitais próprios, ou seja, não alavancada financeiramente com recursos de terceiros.

No caso de empresas que possuem dívidas, para se chegar ao valor líquido da empresa pelo método do fluxo de caixa da empresa, é necessário deduzir-se o valor atualizado destas, descontando-as pelas taxas de risco do referido segmento de atuação da empresa. Assim: 


$$
V E \quad=\quad V P \quad-\quad \begin{gathered}
\text { Dívidas } \\
\text { atualizadas }
\end{gathered}
$$

Onde:

$V E=$ Valor Líquido da Empresa;

$V P=$ Valor total da empresa, obtido a partir do desconto do fluxo de caixa do ponto de vista da empresa.

Pode-se também, utilizar o fluxo de caixa descontado do ponto de vista do acionista para se chegar ao valor líquido da empresa. Eventuais vantagens fiscais existentes sobre os encargos devem ser acrescidas no fluxo de caixa, contribuindo positivamente neste caso, no valor líquido da empresa.

Martins et al. (2001) afirmam que, o valor econômico da empresa representa o potencial de geração de riqueza que os ativos da empresa propiciam ou, que se espera que venham a propiciar, independentemente da forma em que esses ativos são financiados. Chega-se assim ao valor da empresa caso ela fosse financiada exclusivamente com capitais próprios. Já o valor para os acionistas é calculado pelo fluxo de caixa líquido, após, computados os efeitos de todas as dividas tomadas para financiar a empresa. Esse fluxo de caixa representa o valor que realmente está disponível para os acionistas. Resumidamente pode-se representar os dois tipos de fluxo de caixa nos quadros 5 e 6 abaixo: 


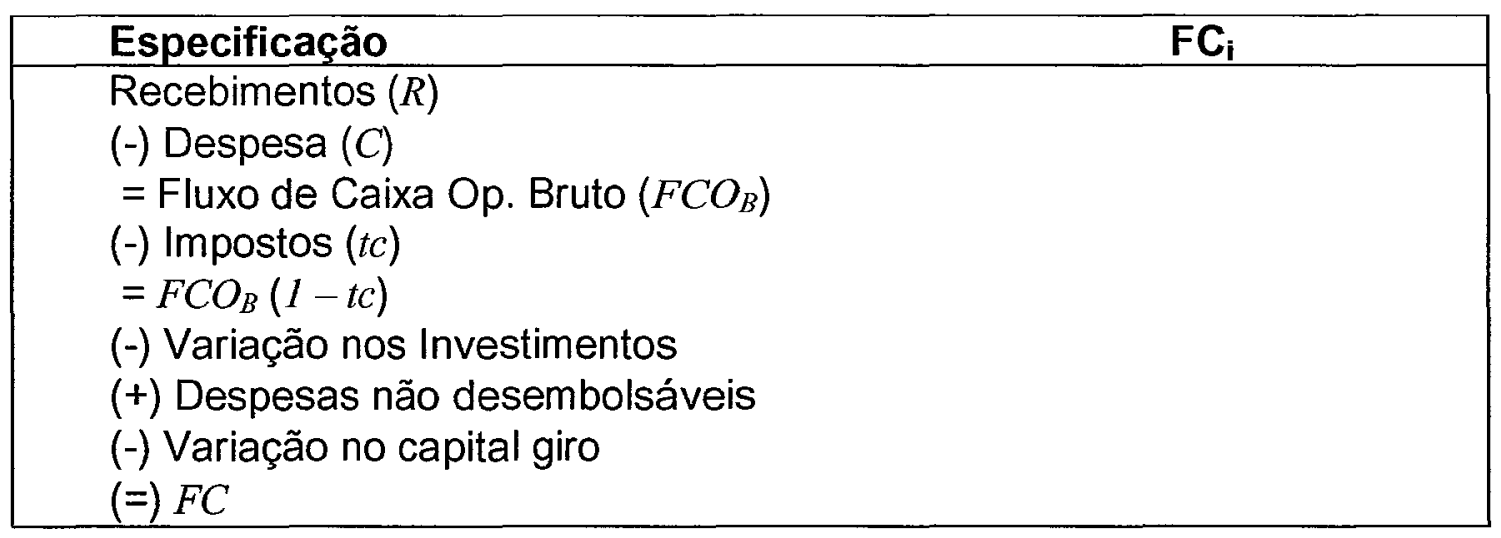

Quadro 5 - Fluxos de Caixa do ponto de vista da Empresa.

Fontes: Elaborado pelo autor, adaptado de Lapponi (1996), Copeland (2000) e Damodaram (2001)

\begin{tabular}{|c|c|}
\hline Especificação & $\mathrm{FC}_{\mathrm{i}}$ \\
\hline $\begin{array}{l}\text { Fluxo de Caixa Operacional } \\
\text { (-) Desp.financeiras acrescidas de reduções nos } \\
\text { impostos: i }(1-t c) \\
\text { (-) Amortização financiamento } \\
+ \text { Novos financiamentos } \\
=F C L\end{array}$ & \\
\hline
\end{tabular}

Quadro 6 - Fluxos de Caixa Livre do ponto de vista do acionista.

Fontes: Elaborado pelo autor, adaptado de Copeland (2000) e Damodam (2001)

Autores como Finnerty (1999), Galesne et al. (1999) afirmam que, o método do valor presente líquido é apropriado ao uso de avaliação de empresas e desenvolvimento de projetos financeiros, inclusive os "Project Finance".

Vieira (1998) utilizando-se do instrumental computacional Excel e da linguagem Visual Basic, avalia economicamente, micro e mini usinas de leite na região de Marília, Estado de São Paulo utilizando-se do método do valor presente liquido considerado pelo autor como adequado ao tratamento daquele assunto. 
Martins (2000) considera ainda que os diversos métodos de avaliação de empresas podem ser utilizados conjuntamente, desde que se considerem dois itens de fundamental importância, que é a inflação e o custo de oportunidade, tratando, pois, o assunto de forma intertemporal. O autor conclui que os métodos com base na avaliação contábil e do valor presente líquido são complementares e não devem ser tratados isoladamente, e que a pesquisa e a prática devem buscar modelos integradores, pois todos os métodos buscam um único objeto que é o caixa.

\subsubsection{Custo do Capital}

A utilização do método do valor presente exige a escolha correta da taxa de desconto apropriada a classe de risco da empresa analisada.

Segundo Damodaram (2001) a escolha da taxa incorreta para descontos dos fluxos de caixa pode levar a um viés no valor da empresa. A taxa de desconto a ser utilizada na atualização dos valores obtidos nos fluxos de caixa do ponto de vista da empresa deve refletir o custo de capital de cada uma das fontes de financiamentos, próprios ou de terceiros, ponderada por sua contribuição ao capital da empresa. É o chamado custo médio ponderado de capital. Na composição dele deve-se levar em conta o custo de capital da empresa que é o custo de oportunidade para o investidor, ou seja, a taxa de retorno que estes investidores esperam receber em outros investimentos de risco equivalente. $O$ custo do capital de terceiros refere-se as taxas pactuadas nos contratos de financiamento.

O custo médio ponderado do capital pode ser representado pela equação: 


$$
C M P C=r e \frac{E}{A}+r d \frac{D}{A}
$$

Onde:

$$
\begin{aligned}
& C M P C=\text { Custo Médio Ponderado do Capital; } \\
& D=\text { Valor dívida; } \\
& E=\text { Valor patrimônio líquido; } \\
& A=\text { Total ativo; } \\
& r e=\text { Custo do capital próprio ou custo de oportunidade; } \\
& r d=\text { Custo das dívidas pactuadas; }
\end{aligned}
$$

Ao se descontar o fluxo de caixa na ótica do acionista, Damodaram (2001) recomenda a utilização do custo de oportunidade exigido pelos detentores do capital, como taxa de desconto. A formação desta taxa deve englobar uma taxa de mercado considerada livre de risco, acrescido de um prêmio pelo risco assumido pelo empresário. Na quantificação do prêmio deve-se levar em conta a volatilidade do mercado em que se insere a empresa, representada pelo coeficiente $\beta$, multiplicado pelo spread entre retorno médio do mercado e a taxa livre de risco.

$$
C o=\mathrm{r}_{f}+\beta\left(\mathrm{r}_{p}\right)
$$

Onde:

Co = Custo do capital ou custo de oportunidade;

$r_{f}=$ Taxa livre de risco; 
$r_{p}=$ Diferença entre o retorno médio do mercado e a taxa livre de risco;

$\beta=$ Coeficiente relacionado ao risco da indústria.;

No caso de se optar pelo desconto do fluxo de caixa do ponto de vista da empresa e do respectivo fluxo das dívidas acrescidas dos encargos, a taxa de desconto utilizada nos dois fluxos deve corresponder ao custo do capital próprio ou custo de oportunidade, refletindo a classe de risco da empresa.

É importante salientar que essas taxas de desconto devem representar valores reais ou deflacionados na medida em que os fluxos de caixa são projetados em valores constantes.

O Valor Econômico da Empresa cresce em situações onde a taxa de retorno ou custo do capital próprio seja maior que o CMPC (Custo Médio Ponderado do Capital). Copeland (2000) simula situações onde, mantendo a taxa de retorno menor que o custo médio ponderado de capital, o Valor Econômico da Empresa diminui mesmo com o crescimento do Fluxo de Caixa Operacional.

Para Azevedo Filho (2001) o valor atual dos fluxos líquidos de um projeto é obtido a partir do desconto da diferença entre fluxos de benefícios e fluxos de custos, a uma determinada taxa de desconto. Embora reconheça que este método é o mais consistente dos indicadores disponíveis, traz a limitação de não apresentar sensibilidade à escala de um empreendimento. A escolha da taxa de desconto, dependendo de seu valor, pode alternar escolhas entre dois ou mais investimentos. 


\subsubsection{Período da Projeção}

Copeland et al. (2000) chamam a atenção para o tempo de projeção. Como as empresas não têm prazo de duração definido, os autores recomendam separar a análise do valor em dois períodos. O Valor Econômico da Empresa é obtido pela soma do Valor Presente dos fluxos de caixas no período um, que é resultado da projeção no período considerado, e o Valor Presente do período dois que é chamado também Valor Residual ou Valor da Perpetuidade.

Para se obter o valor do segundo periodo, também chamado valor residual ou valor da perpetuidade, utiliza-se o resultado operacional do último ano do $1^{\circ}$ fluxo de caixa, como o do primeiro ano do $2^{\circ}$ período e desconta-se o mesmo pelo custo médio ponderado de capital, ou pelo custo de oportunidade dependendo do critério utilizado para se obter o fluxo de caixa de acordo com a equação:

$$
V \mathrm{r}=\frac{F C_{n+1}}{C M P C} \quad \text { ou } \quad V \mathrm{r}=\frac{F C_{n+1}}{C O}
$$

Onde:

$V r$ = Valor residual;

$F C_{n+1}=$ Fluxo de Caixa no período imediatamente seguinte ao período de projeção;

$C M P C=$ Custo Médio Ponderado do Capital;

$\mathrm{CO}=$ Custo de Oportunidade.

Esta equação corresponde àquela utilizada por Azevedo Filho (2001), que é o valor de ativos com rendimento perpétuo. Importante salientar 
que o residual ou perpetuidade entrará na formação do fluxo de caixa do último ano do $1^{\circ}$ período de análise.

Provavelmente, a maior crítica que o método do valor presente pode receber é a definição do horizonte de projeção dos benefícios e custos. No entanto, uma boa base de dados com um tratamento adequado das informações pode contribuir para que este assunto não seja fator limitante da análise.

Está claro que ao se tratar de previsões, à medida que se projeta por um número maior de anos, a possibilidade de erros provavelmente aumenta, mas o fato de se considerar a perpetuidade da empresa em um período longo faz com que o valor do fluxo de caixa descontado do último período se aproxime de zero, não influenciando, pois, significativamente, o valor presente.

Martins et al. (2001) partindo de um exemplo hipotético mostram que quando se projeta todas as variáveis com a mesma taxa de crescimento o valor presente calculado para 254 períodos de fluxo de caixa é igual ao valor calculado para 10 anos mais a perpetuidade. Copeland sugere o uso de um período de tempo de 70 anos.Quando se tem taxa de desconto mais elevada, acima de $10 \%$ ao ano, um horizonte de tempo acima de 30 anos pode ser suficiente para uma boa aproximação do valor da empresa.

O exemplo citado por Martins et al. (2001) , ou seja, o uso do critério da perpetuidade, encontra base teórica no modelo Gordon e Shapiro, apud Bussey (1999), onde o valor presente é obtido pela equação: 


$$
P_{0}=D_{0} \frac{1}{(K e-r b)}
$$

Onde:

$P_{0}=$ Valor Presente;

$D_{0}=$ Fluxo de Dividendos;

$K e=$ Custo do Capital;

$r=$ taxa de retorno do capital;

$b=$ taxa de reinvestimento. 


\section{TEORIA DA AVALIAÇÃO ECONÔMICA}

Falcini (1995) calcula o valor econômico de empreendimentos no Brasil, tendo como referencial teórico o modelo desenvolvido por Gordon e proposto por Modigliani e Miller.

Millan (1992) analisa a composição ótima da estrutura de capital de uma empresa, utilizando-se também do modelo Modigliani e Miller (MM) e do modelo proposto por Bradley et al. (1984). A partir do relaxamento de determinadas hipóteses do Modelo MM, principalmente da informação perfeita, este autor cita trabalhos que procuram justificar uma estrutura ótima de capital motivado pela existência de custos de falências, possibilidade de expropriação de riqueza dos credores, a presença do custo de agência e assimetria de informações.

Para Modigliani e Miller (MM), citado em Millan (1992), a estrutura de capital, que é formada pela participação de capital próprio e de terceiros, é irrelevante para a determinação do valor da Empresa. Este trabalho de MM definiu a linha de pensamento econômico sobre decisões de financiamentos. Foram formuladas duas proposições partindo-se das hipóteses citadas a seguir:

- O mercado de capitais é perfeito; isto é, há presença de muitos compradores e vendedores, não há custos ou taxas de transação, todos os ativos são perfeitamente divisiveis, e não há regulamentações restritivas; 
- Qualquer indivíduo pode emprestar e tomar emprestado à taxa livre de risco;

- Não há custos de falência;

- A empresa utiliza somente dois tipos de fontes de recursos: capital de terceiros à taxa livre de risco e capital próprio;

- Todas empresas pertencem a uma mesma classe de risco;

- Impostos sobre lucros das empresas constituem a única forma de arrecadação do governo, isto é, não há impostos pessoais;

- Todos os fluxos de caixa são perpétuos e uniformes, isto é, não crescem;

- Todos os individuos possuem o mesmo nível de informação;

- Os administradores sempre maximizam a riqueza dos acionistas.

Assim, proposição I de $\mathrm{MM}$, diz que: "O valor de mercado de qualquer empresa é independente de sua estrutura de capital e é dada pela capitalização de seu retorno esperado a taxa apropriada à sua classe de risco". MILLAN (1992, p.8).

Algebricamente a proposição I pode ser representada por:

$$
V=E+D=\frac{\bar{R}}{\rho}
$$

Onde:

$V=$ Valor Total da Empresa;

$E=$ Valor do Capital Próprio ou Patrimônio líquido;

$D=$ Valor da Dívida Atualizada 
$\bar{R}=$ Retorno esperado sobre os ativos da empresa, isto é, o lucro esperado antes de deduzir os juros;

$\rho=$ Taxa de desconto apropriado à taxa de risco, o custo médio ponderado de capital, ou o custo do capital próprio de uma empresa não alavancada financeiramente. É conhecida também como expectativa de retorno da empresa.

A proposição II de MM é representada algebricamente por:

$$
r e=\rho+(\rho-r d) \frac{D}{E}
$$

Onde :

re = Taxa esperada de retorno de uma empresa com dívidas, ou, o custo do capital próprio de uma empresa alavancada financeiramente;

$r d$ = Taxa livre de risco, ou, o custo de capital de terceiros;

$\frac{D}{E}=$ Relação capital terceiro e capital próprio.

Como pela proposição I, o custo médio ponderado de capital ( $C M P C)$ não se altera com modificações da estrutura de capital, e pela proposição II, o custo do capital próprio (re) cresce linearmente com o endividamento $(D / E)$, tem-se que a taxa de retorno esperada decresce quando a taxa livre de risco aumenta, que é a taxa de captação de empréstimo, mantendo constante o custo médio ponderado de capital. Isto significa dizer que o risco não sofre alterações, o que muda é a divisão dele entre os possuidores de ações ou de títulos da divida. 
Matos (2001) também utilizando o modelo MM apresenta que, partindo de uma empresa que tenha a estrutura de capital composta por recursos de credores e de acionistas, tem o seu valor equivalente ao de uma empresa com capitais unicamente de acionistas. Isso pode ser demonstrado a partir de uma empresa hipotética que possua um fluxo de caixa $V_{j(T)}$, suficiente para atender os encargos originados da dívida $D_{j(T)}$ e as expectativas do acionistas que esperam receber $S_{j(T)}$. O valor da dívida no momento presente pode ser representado pela equação:

$$
D=\frac{D_{j_{(T)}}}{f_{j}}=\sum_{j=0}^{\infty} \frac{D_{j(T)}}{(1+R)^{t}}
$$

Onde:

$D=$ Valor atual da divida;

$D_{j(T)}=$ Valor nominal dos encargos dívida continua e constante;

$D_{j}=$ Valor nominal da dívida no horizonte de tempo;

$f_{j}=$ Fator de desconto a uma determinada taxa de risco;

$R=$ Taxa de risco;

$t=$ determinado período num horizonte de tempo;

$j=$ tempo.

O valor que os acionistas esperam receber $S_{j_{(t)}}$, pode ser representado pela diferença entre o valor do fluxo de caixa total menos o valor de quitação das dívidas, que pode ser representado pela seguinte equação: 


$$
S_{j_{(T)}}=V_{j_{(T)}}-D_{j(T)}
$$

Onde:

$S_{j(T)}=$ Valor do fluxo de caixa destinado aos acionistas;

$V_{j(T)}=$ Valor do fluxo de caixa total;

$D_{j(T)}=$ Valor nominal da dívida num determinado período.

O Valor presente destinado aos acionistas equivale ao patrimônio líquido da empresa e pode ser representado por:

$$
S=\frac{S_{j(T)}}{R}=\sum_{j=0}^{\infty} \frac{S_{j(T)}}{(1+R)^{t}}
$$

Onde:

$S=$ Valor presente do fluxo de caixa destinado aos acionistas.

Numa empresa que não possua dívidas o valor destinado aos acionistas, pode ser representado por:

$$
V=\frac{V_{j(T)}}{R}=\sum_{i=0}^{\infty} \frac{V_{j(T)}}{(1+R)}
$$

Onde: 
$V=$ Valor presente líquido do fluxo de caixa.

Desde que $S=V-D$, temos que o valor de uma empresa alavancada financeiramente é igual ao de uma empresa não alavancada. Está demonstrada assim a proposição I de $\mathrm{MM}$ e representada na equação:

$$
V_{L}=S+D=\sum_{j=0}^{\infty} \frac{D_{j(T)}+S_{j(T)}}{(1+R)^{t}}=\sum_{j=0}^{\infty} \frac{V_{j(T)}}{(1+R)^{\prime}}=V_{U}
$$

Onde:

$V_{L}=$ Empresa alavancada com financiamentos;

$V_{U}=$ Empresa não alavancada através de financiamentos.

A proposição II do modelo MM também é explicada por Matos (2001), afirmando que a expectativa de retorno do acionista ou o seu custo de capital é igual a expectativa de retorno do empreendimento mais um prêmio relativo ao risco de mercado, que é obtido pelo produto da diferença entre retorno da empresa e a taxa livre de risco do mercado multiplicado pela razão divida com patrimônio liquido. Algebricamente esta proposição pode ser obtida a partir da expectativa de retorno $R_{e}$ do custo da dívida $R_{d}$, do custo do capital próprio $\mathrm{R}_{\mathrm{p}}$ e do custo médio ponderado do capital $\bar{R}$.

A expectativa de retorno é obtida a partir de: 


$$
R_{E}=\frac{V_{j(T)}}{V} \therefore V_{j(T)}=R_{e} \cdot V
$$

O custo da dívida pode ser representado por:

$$
R_{d}=\frac{D_{j(T)}}{D} \therefore D_{j(T)}=R_{d} . D
$$

O custo de capital próprio pode ser representado por:

$$
R_{P}=\frac{V_{j(T)}-D_{j(T)}}{S} \therefore R_{P}=\frac{R_{e} \cdot V}{S}-\frac{R_{d} \cdot D}{S}
$$

Como visto anteriormente:

$S=$ patrimônio líquido;

$D=$ valor da dívida.

Tem-se que:

$$
R_{P}=R_{e} \frac{(S+D)}{S}-R_{d} \frac{D}{S}
$$

E, 


$$
R_{p}=R_{e}+\frac{R_{e} D}{S}-R_{d} \frac{D}{S}
$$

Chega-se a equação, que é a proposição II de MM:

$$
R_{p}=R_{e}+\left(R_{e}-R_{d}\right) \frac{D}{S}
$$

Finalmente, o custo médio ponderado do capital, que vem a ser a média ponderada do custo do capital próprio e o custo da dívida e pode ser representado por:

$$
\bar{R}=C M P C=\frac{E\left\lfloor S_{j(T)}+D_{j(T)}\right\rfloor}{V}
$$

E substituindo pelas equações anteriores tem-se que:

$$
\bar{R}=R_{e} \frac{S}{V}+R_{d} \cdot \frac{D}{V}
$$

Que também pode ser representada por:

$$
\bar{R}=R_{e} \theta+R_{d}(1-\theta)
$$

Onde: 
$\theta=$ Proporção de capital próprio;

1- $\theta=$ Proporção da dívida.

O Modelo MM se amplia na presença de impostos, sendo que a incidência deste sobre o lucro e podendo ser abatido como despesas financeiras, fazem com que o endividamento seja compensador (Millan:1992).

Assim, uma empresa alavancada financeiramente tem o seu valor maior que uma não alavancada, representando-se algebricamente, como:

$$
V^{t}=V^{a}+t c \cdot D
$$

Onde:

$V^{L}=$ Valor presente de uma empresa alavancada financeiramente;

$V^{u}=$ Valor presente de uma empresa não alavancada;

$t c=$ Alíquota de imposto de renda;

$D=$ Capital de terceiros;

Na presença de impostos a proposição II passa a ser calculada:

$$
r e=\rho+(1-t c)(\rho-r d) \cdot \frac{D}{E}
$$

Onde $t c=$ alíquota de imposto de renda pessoa jurídica

$\mathrm{Ou}$, 


$$
R=C M P C=\rho[1-t c \cdot D /(D+S)]
$$

Assim o ganho obtido pela alavancagem financeira é:

$$
G=V^{L}-V^{u}=t c . D
$$

A existência de impostos pessoais altera a fórmula (4) para:

$$
G=1-\left[\left(\frac{(1-t c)(1-t e)}{(1-t b)}\right)\right] * B
$$

Onde:

$t e=$ Imposto de renda pessoa física detentora de ações, quando receber dividendos;

$t b=$ Imposto de pessoa física que empresta recursos financeiros.

Admitindo-se que te $=0$ e que $t c=t b$ o ganho no valor da empresa corresponde a $G=0$, ou seja, não há acréscimo no valor da Empresa.

$$
\text { Caso } t b=t e=0, \text { temos } G=t c . D
$$

Nota-se, pois, que a alavancagem financeira torna-se interessante quando se pode utilizar eventuais vantagens de ordem fiscal.

Falcini (1995), realça que anteriormente a Miller e Modigliani, Willians em 1938, concluía que o valor econômico ou real (valor do 
investimento) de uma ação é o valor presente (descontado a taxa apropriada) de todos os seus dividendos líquidos futuros e perpétuos, devidamente ajustados por modificações no poder de compra da unidade monetária utilizada. Destaca no texto a questão do custo de oportunidade do capital investido, ou seja, a remuneração mínima que ele exige pela abstinência do consumo no tempo, transferindo-o para o tempo 1, remuneração esta também conhecida como taxa de juros. Acrescenta que taxas de longo prazo podem ser alteradas, o que leva admitir a possibilidade de descontar fluxos de caixa a taxas diferenciadas.

Para se demonstrar o fundamento teórico do uso do modelo de fluxo de caixa descontado para avaliação de empresas, Falcini (1995) apresenta cinco situações em que uma empresa possa estar enquadrada:

a) Empresas não são alavancadas financeiramente e que possuem Fluxo de Caixa Operacional (FCO) constante;

b) Empresas não alavancadas financeiramente, mas que tenham crescimento do FCO, motivados por reinvestimento de parcela do resultado;

c) Idem com crescimento perpétuo (Modelo Gordon);

d) Empresas não alavancadas financeiramente com crescimento superior ou inferior ao custo de capital;

e) Empresas alavancadas financeiramente em um contexto de imposto de renda.

O primeiro modelo é obtido a partir da taxa de retorno requerida pelo mercado, ou taxa de custo de capital. Assim: 


$$
\rho_{t+1}=\frac{d_{i(t+1)}+P_{i(t+1)}-P_{i(t)}}{P_{i(t)}}
$$

Onde:

$\rho_{t+1}=$ Taxa de retorno requerida pelo mercado durante 0 período t;

$$
\begin{aligned}
& d_{i(t+1)}=\text { Dividendos por ação pagos no fim do período t; } \\
& P_{i(t+1)}=\text { Preço por ação cotado pelo mercado no fim do período t; } \\
& P_{i(t)}=\text { Preço da ação cotado pelo mercado no inicio do período t. }
\end{aligned}
$$

Ou seja, a taxa de retorno é obtida pela razão entre a soma dos dividendos obtidos no final do período mais os ganhos de capital divididos pelo preço inicial da ação.

O valor de mercado da empresa será obtido a partir do somatório dos valores individuais das ações que compõem o seu capital.

$$
V_{i(t)}=\frac{D i_{(t+1)}+n_{i(t) .} P_{i(t+1)}}{1+\rho_{t+1}}
$$

Onde:

$V_{\mathrm{I}(\mathrm{t})}=$ Valor da empresa no momento presente ou $n_{\mathbf{i}(\mathrm{t})}{ }^{*} P_{\mathbf{i}(\mathbf{t})} ;$

$D i=$ Soma dos dividendos pagos no fim do período $\mathrm{t}$;

n. $P_{i}=$ Valor total das ações no final do período t que é igual a $V_{\mathrm{i}}$ $(\mathrm{t}+1)$

$$
\rho_{t+1}=\text { Taxa de retorno requerida pelo mercado no período } t \text {. }
$$


Esta equação é obtida a partir da equação 33 , multiplicando o $2^{\circ}$ termo por $n_{i(t)}$ que é o número de ações da empresa, e isolando $n_{i(t)}{ }^{*} P_{i(t)}$

Assim, como primeira conclusão, para se obter o Valor da Empresa desconta-se o fluxo de caixa projetado, obtendo-se o Modelo Modigliani e Miller. Esta mesma equação pode ser escrita partindo-se da igualdade das aplicações e usos dos fundos da seguinte forma, resultando conforme Falcini (1995):

$$
V_{i(t)}=\frac{F C O_{i(t+1)}-I_{i(t+1)}+V_{i(t+1)}}{1+\rho_{(t+1)}}
$$

Onde:

$$
\begin{aligned}
& V_{i(t)}=\text { Valor da empresa no momento presente; } \\
& F C O_{i(t+1)}=\text { Fluxo de Caixa Operacional no período t; }
\end{aligned}
$$

$I_{i(t+1)}=$ Investimento necessário para a continuidade $\mathrm{e}$ crescimento da empresa no período t;

$V i_{i(t+1)}=$ Valor residual da empresa no final do período $\mathrm{t}$.

Lembrar que $D_{i(t+1)}=F C O_{i(t+1)}-I_{i(t+1)}$.

Verifica-se, pois, que nesta equação o item dividendos desaparece da fórmula de avaliação, confirmando assim a proposição de Modigliani e Miller 
apud Falcini (1995) de que, na inexistência de imposto de renda e custos de transações mobiliárias, a empresa pode optar por qualquer política de pagamento de dividendos que preferir, pois isso não afetará o montante dos fluxos de caixa a serem recebidos pelos seus financiadores em relação aos seus investimento na empresa.

O segundo modelo, no caso de empresas não alavancadas financeiramente e que estejam em crescimento dos fluxos operacionais de caixa gerados pela empresa, é obtido a partir da equação anterior chegando a:

$$
V_{0}=\frac{F C O_{1}-I_{i}}{1+\rho}+\frac{F C O_{2}-I_{2}}{(1+\rho)^{2}}+\ldots \frac{F C O_{n}-I_{n}}{(1+\rho)^{n}}+\frac{V n}{(1+\rho)^{n}}
$$

Nota-se que o crescimento do fluxo operacional do caixa depende da realização de novos investimentos que sejam em montante superior a necessidade de reposição do capital depreciado.

Considerando-se um modelo com projeção de um horizonte de tempo infinito, pode-se expressá-lo pela equação:

$$
V_{0}=\operatorname{Lim}_{n \rightarrow \infty} \sum_{t=1}^{n} \frac{F C O_{t}-I_{t}}{(1+\rho)^{n}}
$$

Estas equações mostram que o Valor Presente da Empresa é o somatório dos Fluxos de Caixas Operacionais, menos os novos investimentos realizados, descontados a taxa $\rho$. Tal fluxo pode ser esquematizado no quadro 7. 


\begin{tabular}{|lcc|}
\hline Período & Entradas & Saidas \\
\hline 1 & $F C O_{1}$ & $-\mathrm{I}_{1}$ \\
2 & $\mathrm{FCO}_{2}=F C O_{1}+r_{1} \cdot I_{1}$ & $-\mathrm{I}_{2}$ \\
3 & $F C O_{3}=F C O_{1}+r_{1} \cdot I_{1}+r_{2} \cdot I_{2}$ & $-\mathrm{I}_{3}$ \\
$\vdots$ & $\vdots$ & $\vdots$ \\
$\mathrm{N}$ & $F C O_{n}=F C O_{1}+\sum_{\tau=1}^{n-1} r_{\tau} I_{\tau}$ & $\mathrm{I}_{\mathrm{n}}$ \\
Onde $\tau=\mathrm{t}+1$ & & \\
\hline
\end{tabular}

Quadro 7 - Visualização do Fluxo de Caixa no horizonte de tempo n.

Fonte: Falcini (1995)

Somando-se os resultados dos fluxos de caixa $\left(\mathrm{FCO}_{\mathrm{t}}-\mathrm{I}_{\mathrm{t}}\right)$, descontados a uma determinada taxa de juros tem-se:

$$
V_{0}=\frac{F C O_{1}-I_{1}}{1+\rho}+\frac{F C O_{1}+r_{1} \cdot I_{1}-I_{2}}{(1+\rho)^{2}}+\ldots+\frac{F C O_{1}+\sum_{\tau=1}^{n-1} r_{\tau} \cdot I_{\tau}-I_{n}}{(1+\rho)^{n}}
$$

Reordenando os termos tem-se:

$$
V o=\frac{F C O_{1}}{(1+\rho)}+\frac{F C O_{1}}{(1+\rho)^{2}}+\cdots+\frac{F C O_{1}}{(1+\rho)^{2}}+I_{1}\left(\frac{r_{1}}{(1+\rho)^{2}}+\frac{r_{1}}{(1+\rho)^{3}}+\frac{r_{1}}{(1+\rho)^{2}}-\frac{1}{1+\rho}\right)+I_{2}\left(\frac{r_{2}}{(1+\rho)^{3}}+\frac{r_{2}}{(1+\rho)^{4}}+\cdots+\frac{r_{2}}{(1+\rho)^{2}}-\frac{1}{(1+\rho)^{2}}\right)+\cdots
$$

Esse resultado pode ser generalizado na equação (39) :

$$
V_{0}=\sum_{t=1}^{n} \frac{F C O_{1}}{(1+\rho)^{\gamma}}+\sum_{t=1}^{n} I_{t} *\left[\left(\sum_{\tau=t+1}^{n} \frac{r_{t}}{(1+\rho)^{c}}\right)-\left(\frac{1}{(1+\rho)^{\gamma}}\right)\right]
$$


O primeiro termo da equação (39) é uma anuidade perpétua com pagamentos constantes podendo ser escrita como:

$$
V_{0}=\operatorname{Lim}_{n \rightarrow \infty} \sum_{t=1}^{n} \frac{F C O_{t}}{(1+\rho)^{n}}=\frac{F C O_{1}}{\rho}
$$

Segundo termo da equação (39) pode ser simplificado:

$$
V_{0}=\sum_{\tau=t+1}^{n} \frac{r_{t}}{(1+\rho)^{\tau}}=\frac{1}{(1+\rho)^{y}} * \sum_{\tau=1}^{n-1} \frac{r_{t}}{(1+\rho)^{\tau}}
$$

Substituindo a simplificação na equação (39), tem-se:

$$
V_{0}=\frac{F C O_{1}}{\rho}+\sum_{t=1}^{n} I_{t} *\left[\frac{r_{t}}{\rho(1+\rho)^{\gamma}}-\frac{1}{(1+\rho)^{\prime}}\right]
$$

Portando quando $n \rightarrow \infty$ :

$$
V_{0}=\frac{F C O_{1}}{\rho}+\sum_{t=1}^{\infty} \frac{I t\left(r_{t}-\rho\right)}{\rho(1+\rho)^{t}}
$$

Segundo Falcini (1995) o primeiro termo da equação representa o valor atual de uma empresa hipotética, que não fez nenhum novo investimento 
permanente; em outras palavras, é o valor econômico de uma empresa cujo o fluxo de fundos de caixa operacional não está crescendo.

O segundo termo demonstra o valor atual dos novos investimentos permanente feitos para o crescimento dos fluxos de caixa operacionais e, esse valor atual depende diretamente do montante dos novos investimentos realizados na empresa, bem como da diferença entre a taxa de retorno gerada internamente pelas operações da empresa sobre o investimento realizado, $r_{t}, e$ a taxa de retorno requerida pelo mercado, $p_{\mathrm{t}}$, para a empresa não alavancada.

Assim, novos investimentos permanentes podem ser feitos na empresa, fazendo crescer seus ativos, que se tiverem taxa de retorno superior aquela requerida pelo mercado, adicionarão valor real ou econômico a empresa.

$\mathrm{Na}$ seqüência são apresentados resumidamente os demais modelos ${ }^{3}$ citados .

O terceiro modelo é obtido a partir do trabalho de M. J. Gordon em 1962 e dá origem a um modelo chamado "Modelo de Dividendos", aplicável a empresas não alavancadas financeiramente, em crescimento perpétuo a uma taxa constante, segundo Falcini (1995), a partir de algumas hipóteses básicas:

- Inexistência de taxação sobre a renda;

- A taxa de retorno esperado pelo investidor ou custo de capital da empresa deve ser sempre maior que a taxa de crescimento dos fluxos de caixa operacional.

\footnotetext{
${ }^{3}$ Modelos expostos em Falcini (1995) p.181-194 com base em Copeland et al.
} 
O modelo de Gordon pode ser deduzido a partir da equação (44) e escrito algebricamente como:

$$
V_{0} u=\frac{d_{1}}{\rho-g}
$$

Onde

$V_{0} u=$ Valor da Empresa não alavancada financeiramente, no momento presente;

$d_{1}=$ Dividendo líquido a ser pago no período;

$\rho=$ Taxa de retorno esperado pelos investidores;

$g=$ Taxa de crescimento do fluxo de caixa operacional.

A taxa de crescimento do fluxo de caixa operacional pode ser obtida pela equação:

$$
g=k \cdot r
$$

Onde:

$k$ = taxa de retenção ou proporção do FCO já deduzido os investimentos de reposição para manutenção e retidos para proporcionar o crescimento do fluxo de caixa futuro; 
$r=$ Taxa de retorno esperado ou custo de capital.

Como se pode notar, fica comprovada tanto a validade de proposição M.M. sobre a irrelevância da política de dividendos na avaliação de empresas, como pelo mesmo caminho dedutivo chega-se a fórmula básica de dividendos de Gordon para avaliação de empresas.

O quarto modelo, eliminando a condição de crescimento econômico infinitamente mantido a uma taxa superior a da economia, o que significa dizer que a empresa cresce um determinado período de tempo $(\tau)$ após o que $r=\rho$, estabilizando o valor da empresa, é dado pela equação 46:

$$
V_{0}=\frac{F C O_{1}}{\rho}+k\left(F C O_{1}\right) \tau \frac{r-\rho}{\rho(1+\rho)}
$$

Onde:

$$
\tau=\text { número de períodos em que são realizados novos }
$$

investimentos.

E finalmente na presença de impostos e de alavancagem financeira,

$$
V_{0}=\frac{F C O_{1}(1-t c)}{\rho}+t c \cdot B+k\left[F C O_{1}(1+t c)\right]\left[\frac{r-C M P C}{C M P C(1+C M P C)}\right]
$$

Onde: 
$V_{0}=$ Valor da empresa no momento presente;

$F C O_{1}=$ Fluxo de caixa operacional constante;

$t c=$ Taxa de imposto de renda;

$B=$ Empréstimos mantidos à longo prazo no valor de mercado;

$k=$ Taxa de investimento, que é a proporção retida dos fundos de caixa operacional líquido para novos investimentos;

$\tau=$ número de períodos;

$r=$ taxa de retorno gerada pelas atividades operacionais sobre os novos investimentos;

$C M P C=$ Custo médio ponderado de capital.

Copeland et al. (2000) propõem, com base no modelo de MM, uma forma alternativa e simples para avaliação de Empresas, onde o Valor de Empresa é igual ao Valor resultante dos Ativos existentes acrescido de Valor de Crescimento do fluxo de caixa, ou seja:

$$
V E=\frac{F C O_{B}}{C M P C}+k F C O_{B} \cdot n\left[\frac{r-C M P C}{C M P C(1+C M P C)}\right]
$$

Onde:

$F C O_{B}=$ Lucro operacional deduzido os impostos;

$C M P C=$ Custo médio ponderado de capital;

$k=$ Taxa de investimento, em relação ao $\mathrm{FCO}_{\mathrm{B}}$, para crescimento;

$n=$ Número esperado de anos que se espera que a Empresa continue investindo em novos projetos; 
$r=$ Taxa de retorno esperado sobre o capital investido $\left(\mathrm{FCO}_{\mathrm{B}} /\right.$ Capital Investido.

Assim, conclui-se neste capítulo que a teoria econômica a partir das proposições de Modigliani e Miller e do modelo Gordon ,expostas em Millan (1992), Falcini (1995) e Matos (2001) dá fundamentação teórica ao trabalho chegando-se as conclusões de que:

1) O valor de uma empresa pode ser obtido a partir do desconto dos fluxos de caixa futuros a uma determinada taxa representativa da classe de risco da empresa;

2) O valor da empresa independe do grau de alavancagem financeira da empresa, admitidas as hipóteses do modelo MM;

3) O custo médio ponderado de capital não se altera com variações no grau de alavancagem da empresa;

4) O custo de capital próprio ou a expectativa de retorno do capital próprio, está linearmente relacionado com o nível de endividamento da empresa;

5) Na ausência de endividamento o CMPC é igual a expectativa de retorno da empresa ou o custo de oportunidade do empresário ou custo do capital próprio;

6) O valor de uma empresa alavancada financeiramente pode ser obtido pela soma do valor presente do fluxo de caixa da empresa e do valor presente do fluxo das dívidas acrescidas de seus encargos, descontados a mesma taxa correspondente à classe de risco; 
7) Em economias onde o custo financeiro possa ser deduzido do imposto de renda a pagar, empresas alavancadas financeiramente podem ter valores superiores às não alavancadas;

8) Empresa que possuam fluxo de caixa constante durante a sua vida útil pode ter seu valor calculado de acordo com o modelo desenvolvido por Gordon;

9) Empresas que possuíam novos investimentos, têm seu valor presente acrescido através da incorporação do resultado destes novos investimentos no fluxo de caixa;

10) O valor presente pode ser acrescido ou diminuido no caso da taxa de retorno desses novos investimentos ser maior ou menor que a taxa de desconto adequado às classes de risco da empresa. 


\section{UM MODELO PARA DETERMINAÇÃO DO VALOR DA EMPRESA}

Neste capitulo serão selecionadas as principais variáveis que direcionam o valor da empresa, ou seja, os desembolsos e recebimentos utilizados na formação do fluxo de caixa.

Copeland et. al (2000), sugerem que a avaliação de empresas com vários negócios deve ser segmentada por unidade de negócio. A soma da avaliação separada de cada segmento constituirá o valor da empresa. Ele sugere também que a avaliação não deva conter dupla contagem de valor de ativos. O valor presente líquido obtido já estima o valor de mercado de ativos fixos ou semi-fixos e a parcela de valor da empresa não tangivel.

\subsection{A empresa agrícola}

O segmento agrícola do setor sucroalcooleiro, responsável pelo abastecimento de matéria prima, pode ter suas atividades subdivididas em: fundação, que compreende as áreas de expansão e/ou reforma, colheita destas áreas após o desenvolvimento vegetativo, e cultivo das áreas colhidas visando-se novos cortes. Estes três grandes grupos de atividade compreendem diversas operações que podem ser manuais ou mecanizadas. Na categoria de insumos tem-se o uso de calcário, herbicidas, mudas e fertilizantes químicos ou provenientes de subprodutos da indústria, tais como vinhaça e torta de filtro. 
Basicamente, o ciclo de produção compreende a fundação com uso intensivo de tratores e implementos, o cultivo da lavoura até o ponto de corte, a colheita com uso de cortadores manuais ou colhetadeiras mecânicas, o carregamento mecanizado e o transporte com caminhões específicos para esta operação. A remuneração da cana de açúcar depende da sua qualidade que é medida quimicamente pelo teor de ATR e dos preços dos produtos finais obtidos pela empresa industrial. $\mathrm{Na}$ seqüência são apresentados 0 detalhamento da composição das receitas e os custos envolvidos neste processo de produção. Os resultados detalhados são obtidos na coletânea de planilhas de cálculo em anexo.

\subsubsection{Composição do preço da cana-de-açúcar}

O preço da cana-de-açúcar no Estado de São Paulo é calculado pelo CONSECANA - Conselho dos Produtores de Cana-de-açúcar, Açúcar e Álcool, funcionando como órgão mediador entre usineiros e fornecedores, sendo que no calculo são utilizadas equações que levam em conta qualidade da matéria-prima, mix de produção e o preço dos produtos finais originados da industrialização da cana-de-açúcar.

A qualidade da matéria-prima é medida a partir da determinação do Pol, de pureza, de fibra e do rendimento de processo, obtendo-se a quantidade de ATR numa determinada quantidade de cana-de-açúcar. A seguir apresenta-se as equações básicas para os cálculos do ATR(kq/tonelada de cana).

A equação geral do ATR é expressa por:

$$
A T R=(10 \times R P \times 1,0526 \times P C)+(10 \times 0,88 \times A R C)
$$


Onde:

$\mathrm{RP}=$ rendimento de processo, atualmente estimado pelo CONSECANA em 0,88 ;

$\mathrm{PC}=\mathrm{Pol}$ da cana-de-açúcar;

$\mathrm{ARC}=$ açúcar redutores da cana (\%);

Numericamente chega-se a ATR a partir os seguintes dados médios obtidos numa unidade industrial; que a título de exemplo são relacionados a seguir:

$$
\begin{aligned}
& P C=15,12 \\
& P z a=87,7 \\
& F=12,65
\end{aligned}
$$

Então,

$$
A T R=10 * 0,88 * 1,0526 * 15,12+10 * 0,88 * 0,6205=145,5152
$$

Note-se que há necessidade de se obter primeiro o ARC que é calculado a partir da equação 50 :

$$
A R C=A R \% \text { caldo } \times(1-0,01 \times F) \times(1,0313-0,00575 \times F)
$$

Onde:

AR\%caldo = Açúcar redutores do caldo da cana (\%);

F $=$ Fibra \% cana.

Numericamente com os dados já citados tem-se: 


$$
A R C=0,7411 *(1-0,01 * 12,65) *(1,0313-0,00575 * 12,65)=0,6205
$$

O AR\%caldo, incluído na equação do ARC é calculado pela equação 51:

$$
A R=3,6410-0,0343^{*} \text { Pza }
$$

Numericamente com os mesmos dados tem-se:

$$
A R=3,6410-0,0343 * 87,7=0,7411
$$

A quantidade de açúcar extraída da cana-de-açúcar considerandose $99,7^{\circ} \mathrm{S}$ de polarização é calculada a partir da equação 51 :

AÇÚCAR $\left(99,7^{\circ} \mathrm{Z}\right)=\{10 \times \mathrm{PC} \times 0,88 \times 1,66957 \times[1-40 /(\mathrm{Pza}-1)]\} / 0,997$

Numericamente chega-se a :

$$
A c_{99,7^{\circ} Z}=\frac{10 * 15,12 * 0,88 * 1,6728\left(1-\frac{40}{87,7-1}\right)}{0,997}=120,02
$$

O coeficiente $R=1,66957 \times[1-40 /($ Pza-1)] é chamado de coeficiente de recuperação de açúcar, no caso do açúcar $\left(99,7^{\circ} \mathrm{Z}\right)$.

Para o açúcar tipo VHP a equação 51 passa a ser: AÇÚCAR $\left(99,3^{\circ} Z\right)=10^{*} P C^{*} 0,88^{*} 1,6728(1-40 /$ Pza-1)/0,993 
Neste caso, o coeficiente r é obtido pela equação:

$$
R=1,6728\left(1-\frac{40}{P z a-1}\right)
$$

No processo de fabricação do açúcar resulta uma determinada quantia do mel que não é recuperada como açúcar, e que dá origem álcool anidro residual ( $1 / t$ ) e é obtido pela equação 54:

$$
\operatorname{AEAr}=\{[9,26288 \times \mathrm{PC} \times[1-(1,66957 \times(1-40 /(\mathrm{Pza}-1)))]+8,8 \times \mathrm{AR}))\} \times 0,5504
$$

$$
A E A_{r}=\left(9,26288 * 15,12\left\lfloor 1-\left(1,66957\left(1-\frac{40}{87,7-1}\right)\right)\right]+8,8 * 0,7411\right) * 0,5504=10,768
$$

A constante 0,5504 é chamada de eficiência da destilaria em litros de álcool anidro por kg de ATR, e é resultado da equação:

$$
E=0,6503 \times R F \times R D
$$

Onde :

$\mathrm{RF}=$ Rendimento de fermentação, estimado em 0,855;

$\mathrm{RD}=$ Rendimento de destilação, estimado em 0,99.

A quantidade de álcool anidro direto é obtida a partir da equação: 


$$
Q_{A E A d}=A T R_{A E A d} * 0,5504
$$

Onde o $A T R_{A E A d}$ corresponde a quantidade em quilos destinados a produção do álcool anidro direto.

Da mesma forma, no caso de se optar pela produção de álcool hidratado residual a quantidade obtida será:

$$
\mathrm{AEHr}=[(9,26288 \times \mathrm{PC} \times(1-(1,66957 \times(1-40 /(\mathrm{Pza}-1))))+(8,8 \times \mathrm{AR}))] \times 0,5744
$$

$$
A E H_{R}=\left[\left(9,26288 * 15,12 *\left(1-\left(1,66957 *\left(1-\frac{40}{87,7-1}\right)\right)\right)\right)+(8,8 * 0,7411)\right] * 0,5744=11,238
$$

Onde a constante 0,5744 também é chamada de eficiência da destilaria, porém, em litros de álcool hidratado direto por $\mathrm{kg}$ de ATR, e obtido a partir de:

$$
E=0,6503 \times \operatorname{RF} \times \operatorname{RD} \times 1,04361
$$

Onde a constante 1,04361 corresponde ao coeficiente de transformação do álcool anidro em álcool hidratado.

A quantidade de álcool hidratado direto é obtida por:

$$
\mathrm{QAEHd}=\mathrm{ATR}_{\mathrm{AEHde}} \times 0,5744
$$


O ATR corresponde a quantidade em quilos destinados a produção do álcool hidratado direto.

A partir das relações estequiométricas entre a quantidade de ATR encontrada na matéria prima e o produto final resultante da sua transformação, o CONSECANA apresenta a tabela 9 onde estão mostrados os valores que são utilizados para se obter os diversos produtos a partir de determinadas quantias de ATR.

Tabela 9 - Equivalência entre quantidade de ATR e produtos.

\begin{tabular}{lccc}
\hline Especificação & $\begin{array}{c}\mathrm{Kg} \mathrm{ATR} / \\
\text { Produto }\end{array}$ & $\begin{array}{c}\text { Produto / } \\
\text { ATR }\end{array}$ & $\begin{array}{c}\text { Participação no preço da } \\
\text { matéria-prima }\end{array}$ \\
\hline Açúcar $\left(99,7^{\circ} \mathrm{Z}\right)$ & 1,0495 & 0,9528 & 0,5608 \\
Açúcar $\left(99,3^{\circ} \mathrm{Z}\right)$ & 1,0453 & 0,9567 & 0,5687 \\
AAR & 1,8169 & 0,5504 & $0,5608 / 0,5687$ \\
AHR & 1,7409 & 0,5744 & $0,5608 / 0,5687$ \\
AAD & 1,8169 & 0,5504 & 0,6044 \\
AHD & 1,7409 & 0,5744 & 0,6093 \\
\hline
\end{tabular}

Fonte: CONSECANA (2002b)

Para se calcular o preço da cana-de-açúcar há a necessidade de se ter o " mix " de produção da usina, a quantidade e os preços desses produtos.

Utilizando informações já apresentadas, a quantidade de açúcar é obtida pela equação 60 . 


$$
Q_{a_{\zeta}}=\frac{m i x * Q_{A T R} /\left(1+q_{A E A R} * \frac{E q_{A T R / A E A}}{E q_{A T R / A \varphi}}\right)}{E q_{A T R / a \zeta}}
$$

Numericamente a quantidade de açúcar mercado interno em toneladas,com os dados e cálculos efetuados tem-se:

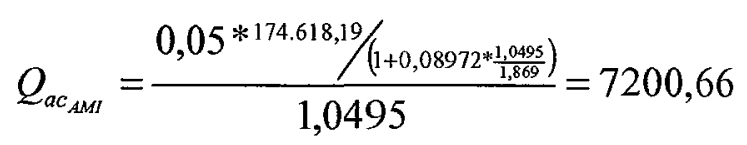

Numericamente a quantidade de açúcar mercado externo será:

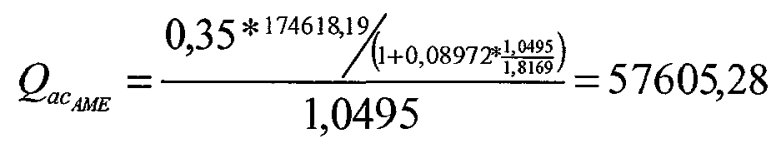

A quantidade de álcool total que e a soma da produção do álcool residual obtido a partir do mel residual do açúcar e do álcool direto destilado a partir do processo de fermentação do caldo e obtida a partir da equação 61 .

$$
\begin{gathered}
Q_{A E A}=\operatorname{prop}_{A E R} * Q_{a \zeta} * q_{A E R}+\frac{M i x^{*} Q_{A T R}}{E q_{A T R} / A E} \\
Q A E A=0,50 *(7200,66+50404,62) * 0,0892+0,30 * \frac{174618,19}{1,8169}=31739,58
\end{gathered}
$$

A quantidade de álcool residual pode ser obtida pela equação 62 que é o primeiro termo da equação. Por diferença pode-se obter a quantidade de álcool direto ou mesmo pela equação representada no segundo termo da equação 61. 


$$
\begin{gathered}
Q_{A E_{R}}=\operatorname{prop}_{A E R}{ }^{*} Q_{a a} * q_{A E R} \\
Q A E A_{R}=0,50 *(7200,66+50404,62) * 0,08972=2907,25
\end{gathered}
$$

Para a determinação do preço da tonelada de cana-de-açúcar deverão ser considerados os seguintes itens:

I - as quantidades, convertidas em quilogramas de ATR conforme os fatores estequiométricos de conversão divulgados em Circular do CONSECANA-SP.da produção total da Unidade Industrial, de cada um destes produtos; que em nosso exemplo será:

a) açúcar cristal especial (mercado interno) AMI);

7557,09

b) açúcar cristal especial e VHP (mercado externo) (AME)

60456,74

c) álcool anidro residual (Aar)

5282,18

d) álcool hidratado residual (Ahr)

5282,18

e) álcool anidro direto (Aad)

52385,46

f) álcool hidratado direto (Ahd)

43654,55

II - os preços médios (PM), convertidos em preço de ATR, praticados durante a safra, já deduzidos os impostos de vendas dos produtos derivados da cana, no exemplo são especificados a seguir:

a) álcool anidro carburante (Mercado Interno e Externo)

$\mathrm{R} \$ 400,44$;

b) álcool hidratado carburante (Mercado Interno e Externo)

$\mathrm{R} \$ 330,84$;

c) álcool anidro industrial

nd.;

d) álcool hidratado industrial (Mercado Interno e Externo)

nd ; 
e) açúcar (Mercado Interno)

$R \$ 519,20$

f) açúcar (Mercado Externo)

$\mathrm{R} \$ 535,33$

III - A participação média $(P)$ do custo de reposição da matéria prima, em relação ao custo médio de reposição de cada produto acabado do item I, conforme divulgado em Circular do CONSECANA-SP. Consta na tabela 9.

Para a determinação do peço médio, em reais, do $\mathrm{kg}$ do ATR da cana-de-açúcar entregue pelo produtor (PATR) deve-se aplicar a seguinte equação:

$$
\begin{gathered}
P A T R=\frac{\left[\left(A M I^{*} P M^{*} P\right)+\left(A M E^{*} P M^{*} P\right)+\ldots+\left(A H D^{*} P M^{*} P\right)\right]}{(A M I)+(A M E)+\ldots+(A H D)} \\
P A T R=\frac{7557,09 * 0,56 * 519+60456,7362 * 0,56 * 535,33+\cdots}{174618,19}=251,95
\end{gathered}
$$

Para a determinação do preço da tonelada de cana-de-açúcar devido ao produtor de cana-de-açúcar aplicar-se-á a seguinte equação:

Preço da cana $=$ PATR $\times$ quantidade de ATR em kg/tonelada de cana-de-açúcar / 1000.

$$
P C=\frac{1000 * 251,95 * 145,1552}{1000}=36,66
$$




\subsubsection{Dados para planejamento Agrícola}

Para determinação das áreas agrícolas utiliza-se de metodologia adotada por Fernandes (2000). Inicialmente determina-se a produtividade da área colhida a partir da equação (64). Neste caso, utilizou-se da premissa de que os viveiros são utilizados como fonte de mudas durante o primeiro e segundo corte. A partir do terceiro corte as áreas de viveiro são incorporadas como áreas de corte comercial.

$$
T C H_{c}=\frac{4 * t^{2} *\left(T C H_{1}+T C H_{2}\right)+\left(4 * t^{2}+2 * t+1\right) * \sum_{e=3}^{n} T C H_{e}}{8 * t^{2}+(n-2) *\left(4 * t^{2}+2 * t+1\right)}
$$

Onde:

$T C H_{c}=$ Produtividade (t/ha) na área colhida;

$t=$ Relação área plantada e área de viveiro;

$\mathrm{TCH}_{1}=$ Produtividade do primeiro corte;

$T C H_{1}=$ Produtividade do segundo corte;

$\mathrm{TCH}_{e}=$ Produtividade a partir do terceiro corte;

$n=$ número de cortes.

Assim considerando-se que a empresa agrícola apresente os dados a seguir:

Produtividade agrícola (t/ha)

$1^{\circ}$ corte: 117

$2^{\circ}$ corte: 100 
$3^{\circ}$ corte: $\quad 84$

$4^{\circ}$ corte: $\quad 70$

$5^{\circ}$ corte: 68

$6^{\circ}$ corte: $\quad 60$

Meta de produção (t): 1.200 .000

Relação de plantio - viveiro: 8

A produtividade $T C H_{c}$ com base nestes dados é calculada como:

$$
T C H_{c}=\frac{4 * 8^{2} *(117+100)+\left(4 * 8^{2}+2 * 8+1\right) *(84+70+68+60)}{8 * 8^{2}+(6-2) *\left(4 * 8^{2}+2 * 8+1\right)}=82,63 \quad \text { t/ha }
$$

A Produtividade por área total é obtida a partir da equação 65 :

$$
T C H_{t}=\frac{1}{n+M} *\left[\frac{\left(T C H_{1}+T C H_{2}\right)}{1+\frac{1}{2 * t}+\frac{1}{4 * t^{2}}}+\sum_{e=3}^{n} T C H_{e}\right]
$$

Onde:

$$
\begin{aligned}
& \left.T C H_{t}=\text { Produtividade ( } \mathrm{t} / \mathrm{ha}\right) \text { por área total; } \\
& M=1 \text { para sistema com cana de ano e meio e } \mathrm{M}=0 \text { para sistema }
\end{aligned}
$$

de cana de ano.

$$
T C H_{c}=\frac{1}{6+1} *\left[\frac{(117+100)}{1+\frac{1}{2^{*}+}+\frac{1}{4^{*} 8^{2}}}+(84+70+68+60)\right]=69,36 \text { t/ha }
$$

A área total é obtida a partir da equação 66 : 


$$
A T_{t}=\frac{C A N A_{t}}{T C H_{t}}
$$

Onde:

$A T_{t} \quad=$ área total;

$C A N A_{t}=$ produção total de cana;

$\mathrm{TCH}_{t}$ = produtividade de cana por hectare;

Numericamente, a área total será:

$$
A T=\frac{1.200 .000}{69,36}=17302,21 \mathrm{ha}
$$

A produção total é obtida a partir da equação 67 :

$$
C A N A_{t}=A T_{t}^{*} T C H_{t}
$$

Numericamente, a produção total de cana será:

$$
C A N A_{t}=17302,21 * 69,36
$$

A área de viveiro primário é obtida a partir da equação 68 .

$$
V P=\frac{A T_{t}}{(n+M) *\left(4 * t^{2}+2 * t+1\right)}
$$


Onde:

$V P=$ Viveiro Primário;

$(n+M)=$ número de cortes; $\mathrm{m}=1$ se cana de 18 meses e $\mathrm{m}=0$ se for cana de ano;

$t=$ a relação área plantada em relação à área de viveiros.

Numericamente,

$$
V P=\frac{17302,21}{(6+0) *(4 * 8+2 * 8+1)}=9,05 \text { ha }
$$

A área de viveiro secundário a partir da equação 69 :

$$
V S=V P * 2 * t
$$

Onde:

$V S=$ área de viveiro secundário.

$$
V S=9,054 * 2 * 8=144,86 \text { ha }
$$

A área de plantio comercial pela equação 70 :

$$
L C=V P * 4 * t^{2}
$$

Onde: 
$L C=$ Área de plantio comercial.

$$
L C=9,054 * 4 * 8^{2}=2317,83 \text { ha }
$$

A área de plantio total 71 :

$$
A P=V P+V S+L C
$$

Onde:

$A P=$ Área de plantio total.

Numericamente,

$$
A P=9,05+144,86+2317,83=2471,74 \text { ha }
$$

A área de colheita a partir da equação 72 :

$$
A C_{t}=V P *\left(8 * t^{2}+(n-2) *\left(4 * t^{2}+2 * t+1\right)\right)
$$

Onde:

$A C_{t}=$ Área de colheita total.

Numericamente, 
$A C_{t}=9,05 *\left(8 * 8^{2}+(6-2) *\left(4+8^{2}+2 * 8+1\right)\right)=14522,63$ ha

A área de soqueira a partir da equação 73 :

$$
A S_{t}=V P *(n-1) *\left(4 * t^{2}+2 * t+1\right)
$$

Onde:

$A S_{t}=$ Área de soqueira total

Numericamente,

$$
A S_{t}=9,054(6-1) *\left(4 * 8^{2}+2 * 8+1\right)=12358,72 \text { ha }
$$

Com estes dados e com o inventário de áreas agrícolas existentes, projeta-se no horizonte de tempo desejado, a evolução da produção agrícola, onde encontra-se a área de viveiros de cana e áreas de corte comercial. Obtém-se também as áreas de fundação da lavoura, área de corte e de tratos culturais que demandarão recursos para a sua condução. $O$ quadro 8 permite a visualização desses valores: 


\begin{tabular}{|c|c|c|c|c|}
\hline Área Agrícola & 0 & 1 & 2 & 3 \\
\hline Area de viv prim & 9 & 9 & 9 & 9 \\
\hline Area viv sec & 141 & 145 & 145 & 145 \\
\hline Area cana planta com & 2350 & 2318 & 2318 & 2318 \\
\hline Area de plantio & 2500 & 2472 & 2472 & 2472 \\
\hline Area de1 corte viv & 150 & 150 & 154 & 154 \\
\hline Area de 2 corte viv & 150 & 150 & 150 & 154 \\
\hline Área de cana 1corte & 2350 & 2350 & 2318 & 2318 \\
\hline Área de cana 2 corte & 1900 & 2350 & 2350 & 2318 \\
\hline Área de cana 3 corte & 1600 & 1900 & 2350 & 2350 \\
\hline Área de cana 4 corte & 1600 & 1600 & 1900 & 2350 \\
\hline Área de cana 5 corte & 1800 & 1600 & 1600 & 1900 \\
\hline Área de cana 6 corte & 1500 & 1800 & 1600 & 1600 \\
\hline Área de cana 7 corte & 0 & & & \\
\hline Área Total & 13550 & 14372 & 14893 & 15615 \\
\hline Fund de viv prim & & 9 & 9 & 9 \\
\hline Fund de viv sec & & 145 & 145 & 145 \\
\hline Fund de area comercial & 2350 & 2318 & 2318 & 2318 \\
\hline Área cana planta & 2350 & 2472 & 2472 & 2472 \\
\hline Área colhida & 11200 & 11600 & 12118 & 12836 \\
\hline Área tratos culturais & 9550 & 10100 & 10822 & 11543 \\
\hline Produção Agrícola & 0 & 1 & 2 & 3 \\
\hline Produção 1 corte & 274950 & 274950 & 271186 & 271186 \\
\hline Produção 2 corte & 190000 & 235000 & 235000 & 231783 \\
\hline Produção 3 corte & 134400 & 159600 & 197400 & 197400 \\
\hline Produção 4 corte & 112000 & 112000 & 133000 & 164500 \\
\hline Produção 5 corte & 122400 & 108800 & 108800 & 129200 \\
\hline $\begin{array}{l}\text { Produção } 6 \text { corte } \\
\text { Produção } 7 \text { corte }\end{array}$ & 90000 & 108000 & 96000 & 96000 \\
\hline Produção Total & 923750 & 998350 & 1041386 & 1090068 \\
\hline Prod. Agr. Média & 82,48 & 86,06 & 85,94 & 84,93 \\
\hline Prod. Total & 68,17 & 69,47 & 69,92 & 69,81 \\
\hline
\end{tabular}

Quadro 8 - Produção da empresa agrícola.

Fonte: Pesquisa de campo

\subsubsection{Dimensionamento de máquinas e equipamentos agrícola}

Para cálculo do número de máquinas e equipamentos necessários para a implantação e condução da lavoura, utilizar-se-á das equações desenvolvidas por Fernandes (2000), para isso será utilizada a equação: 


$$
Q=\frac{a \operatorname{rea}{ }^{*} r^{*} f}{e f^{*} j^{*} n}
$$

Onde:

$$
\begin{aligned}
& Q=\text { Quantidade de máquinas e equipamentos; } \\
& \text { área = área trabalhada; } \\
& r=\text { rendimento em horas por hectare; } \\
& f=\text { freqüência da operação; } \\
& e f=\text { tempo produtivo em índice; } \\
& j=\text { jornada diária; } \\
& n=\text { número de dias disponível. }
\end{aligned}
$$

Como exemplo de aplicação desta equação, numa operação de terraceamento necessária para a fundação 2472 ha de cana-de-açúcar, utilizando-se um trator com potência de $150 \mathrm{cv}$, com rendimento de 0,50 horas/ha, realizando-se esta operação com a freqüência de uma vez, com uma jornada diária de 18 horas, com um tempo produtivo de 0,70 e com 89 dias disponiveis, chega-se ao resultado que mostra o numero de tratores necessários para esta operação:

$$
Q=\frac{2472 * 0,50 * 1,0}{0,70 * 18 * 89}=1,10
$$

\subsubsection{Dados técnicos e econômicos}

Com o cálculo da demanda de horas de trabalho por atividade e, da necessidade de máquinas e equipamentos, estabelece-se a distribuição de uso de máquinas horas pelas atividades de fundação da lavoura, da colheita da 
cana-de-açúcar, e de cultivo de soqueira, bem como a demanda de horas por operações agrícolas tais como preparo de sola, plantio, cultivo, corte, etc, incluídas nas atividades citadas. Neste item também são apresentados os seguintes itens considerados essenciais para calculo dos custos das atividades por hectare. São eles:

Valor inicial das máquinas e equipamentos

Valor residual

Vida útil em anos

Vida útil por hora máquina

Alíquota de seguros

Estimativa de gastos com reparos

Consumo de combustíveis e lubrificantes

Utilização de horas máquinas por hectares

Consumo de combustíveis e lubrificantes por hectare

Reparos por hectare

Com base em Holanda (1974) e Noronha (1981) nos itens seguintes são estruturadas as equações de. custos para elaboração do fluxo de caixa líquido.

\subsubsection{Custos fixos agrícola}

Corresponde aos custos que independem do volume de produção podendo ser desembolsáveis ou não. Podem ser considerados custos fixos: depreciação, seguro do ativo, mão de obra fixa. Custo de administração e diretoria também pode ser alocados como fixos.

Como o trabalho utiliza o método do Valor Presente Líquido, o que interessa é o fluxo de caixa obtido nos diversos períodos de tempo. Assim 
algumas considerações devem ser feitas quanto a questão dos custos fixos. Primeiramente, a depreciação é calculada apenas com o objetivo de calculo de imposto de renda devido, não influenciando diretamente o resultado do fluxo de caixa. Também não são computados juros de qualquer natureza, pois o valor presente é calculado com base em uma determinada taxa de desconto, o que permite verificar se o retorno do investimento atende a expectativa de retorno do empresário.

A depreciação que corresponde à perda de valor que sofrem os ativos durante um determinado período, pode ser originado por fatores físicos (usos ou desgaste) fatores funcionais (obsolescência) ou acontecimentos eventuais (acidentais). Há diversos métodos para cálculo da depreciação, entre eles o método do valor uniforme, comumente usado, e obtido pela fórmula:

$$
D=\frac{V_{i}+V_{r}}{n}
$$

Onde:

$$
\begin{aligned}
& D=\text { Depreciação anual; } \\
& V i=\text { Valor inicial do ativo; } \\
& V_{r}=\text { Valor residual; } \\
& n=\text { Vida útil. }
\end{aligned}
$$

Neste trabalho optou-se em calcular a depreciação dividindo-se o valor inicial pelo número de anos que as máquinas e equipamentos da empresa têm de vida útil. Periodicamente as empresas renovam esses itens, sendo que o seu valor residual é computado na receitas. 
O seguro do ativo refere-se ao valor pago anualmente de seguro

$$
\text { seguro }=\frac{V_{i}+V_{r}}{2} * s
$$

Onde:

$s=$ taxa de seguro em $\%$.

A remuneração do tratorista mais os encargos sociais podem ser considerados como custo fixo, pois os mesmos ficam a disposição da empresa por todo o ano.

O custo da terra foi considerado como sendo exclusivamente propriedade de terceiros, incidindo pois, uma taxa paga ao proprietário da terra, correspondendo ao arrendamento.

Resumidamente, os custo fixos agrícola no exemplo utilizado considerando-se os anos de projeção com estabilidade na produção, estão expressos na tabela 10:

Tabela 10. Custos fixos da empresa agrícola.

\begin{tabular}{lr}
\hline Especificação & \multicolumn{1}{c}{ Valor } \\
\hline Depreciação & 1105227,15 \\
Seguro & 18735,00 \\
Tratorista & 997920,00 \\
Administração & 510660,00 \\
Diretoria & 180000,00 \\
Arrendamento & 8880804,38 \\
Total & 11693346,54 \\
\hline
\end{tabular}

Fonte: Dados da pesquisa 


\title{
4.1.6 Custos variáveis agrícola
}

Custo variável corresponde aos custos que dependem da quantidade produzida e sua estrutura varia de acordo com as características dos bens ou serviços produzidos. Neste trabalho a estrutura de custos variáveis está adequada a área agrícola.

Estes custos estão classificados em três categorias, de acordo com a sua natureza:

\author{
Mecanização \\ Serviços \\ Insumos
}

Nos custos de mecanização estão incluídos consumo de combustíveis e lubrificantes, e reparos de máquinas e equipamentos. Custos referente à alugueis de veículos ou máquinas e equipamentos estão computados pelo valor de mercado.

Nos custo de serviços incluem-se a mão-de-obra necessária nas atividades de fundação, colheita e cultivo de soqueira.

Nos custos de insumos incluem-se os gastos com calcário, fertilizantes, inseticidas, herbicidas, etc. 
Tabela 11. Custos variáveis da empresa agrícola.

\begin{tabular}{lrrrr}
\hline Especificação & Fundação & colheita & soca & total \\
\hline Mecanização & 295,99 & 111,30 & 55,07 & 462,36 \\
Servicos & 122,00 & 660,11 & 75,00 & 857,11 \\
Insumos & 1193,65 & & 433,38 & 1627,03 \\
Total & 1611,63 & 771,41 & 563,45 & 2946,50 \\
\hline
\end{tabular}

Fonte: Dados da pesquisa

\subsubsection{Avaliação da empresa agrícola}

O método selecionado para a empresa, ou seja, o Método do Valor Presente Líquido necessita primeiramente da estruturação do fluxo de caixa líquido que será descontado a um determinada taxa apropriada, assim foi utilizado os seguinte modelo de fluxo de caixa:

(+) Recebimentos

(-) Impostos sobre vendas

(=) Recebimentos líquidos

(-) Custo Total

$(-)$ Custos fixos

(-) Custos variáveis

(-) Fundação

$(-)$ Colheita

(-) Soqueira

$\Leftrightarrow$ Lucro bruto

$(-)$ IR

(-) Depreciação

(=) Fluxo de Caixa Operacional

(-) Reposição Máquinas e equipamentos 
(+/-) Variação capital de giro

$\Leftrightarrow$ Fluxo de caixa liquido

No item recebimentos incluem-se o valor da cana recebida que é obtida a partir da equação:

$$
Q_{c} * P_{c}
$$

Onde:

$Q_{c}=$ quantidade de cana produzida em num determinado período;

$P_{c}=$ preço da cana obtido a partir do método CONSECANA.

Sobre o valor dos impostos sobre vendas incluem-se a ele os encargos com o FUNRURAL a razão de $2,2 \%$ sob o faturamento de cana-deaçúcar, PIS e COFINS a razão de $3,65 \%$ do faturamento.

Os recebimentos líquidos correspondem a diferença entre o valor dos recebimentos e valor dos impostos e contribuições.

O item custo total corresponde a soma dos custos fixos e custos variáveis.

Nos custos fixos incluem-se os valores referentes a depreciação das maquinas e equipamentos que é calculada apenas para efeitos de abatimento do imposto de renda, uma vez que o objetivo do trabalho é a obtenção do fluxo de caixa. Também são considerados custos fixos, os valores referentes a seguros, mão-de-obra-fixa, diretoria, administração agrícola. Os valores correspondentes ao custos do arrendamento também são considerados 
como custos fixos; por se tratar de taxas fixas independentes da quantidade produzida.

Nos custos variáveis incluem-se como já relatados gastos com mecanização, serviços e insumos, referentes a fundação, colheita e cultivo da cana-soca.

O lucro bruto é obtido a partir da diferença entre os recebimentos liquido e o custo total.

Do lucro bruto deduz-se o valor do imposto de renda cujo a alíquota média está em $10 \%$ a.a. e acrescentar-se no fluxo de caixa o valor da depreciação anual que foi computada no custo fixo apenas para uso do benefício fiscal. Obtém-se então o fluxo de caixa operacional.

Do fluxo de caixa operacional deve-se deduzir os valores gastos com investimentos e capital de giro e suas variações nos anos subseqüentes.

Deduzindo-se do fluxo de caixa operacional a variação do capital de giro e a reposição de máquinas e equipamentos, tem-se o valor do fluxo de caixa líquido, que será utilizado para calculo do valor presente líquido.

No cálculo do capital de giro e da sua variação deve-se considerar que a cultura de cana de açúcar é caracterizada por um ciclo relativamente longo, sendo que a fundação da lavoura, na região centro-sul, é realizada de janeiro à abril e colhida no ano seguinte a partir de maio até novembro. Após a colheita deve ser realizado o cultivo da soqueira, obtendo-se uma nova safra após 12 meses, por um período consecutivo de 6 à 7 cortes. 
Assim o capital de giro necessário é composto por despesas de : fundação, colheita e cultivo, podendo ser calculado pela equação:

$$
C G=\frac{\left(G_{\text {fundasão }} * 18\right)+\left(G_{\text {colheita }} * 1\right)+\left(G_{\text {cultivo }} * 12\right)+\left(G_{\text {fixo }} * 12\right)+\left(G_{\text {Fixos-desembolsáveis }} * 12\right)}{12}
$$

Onde:

$$
\begin{aligned}
& C G=\text { Capital de giro; } \\
& G_{\text {fundasão }}=\text { Gastos desembolsáveis com fundações; } \\
& G_{\text {colheita }}=\text { Gastos desembolsáveis com colheita; } \\
& G_{\text {cultivo }}=\text { Gastos desembolsáveis com cultivo; } \\
& G_{\text {fixo }}=\text { Gastos fixos desembolsáveis. }
\end{aligned}
$$

Variação de capital de giro é calculado pela equação:

$$
\operatorname{Var}_{C G}=\begin{gathered}
\text { Capital de Giro do } \\
\text { período }
\end{gathered} \quad \begin{gathered}
\text { Capital Giro do período } \\
\text { do período anterior }
\end{gathered}
$$

Com os dados obtidos na empresa pode-se estruturar o fluxo de caixa da empresa agrícola, sendo que na tabela 12 são apresentados os valores referentes ao ano zero e mais três períodos. É importante citar que o modelo permite projeção por até 70 (setenta) períodos. 
Tabela 12. Fluxo de caixa líquido da empresa agrícola.

\begin{tabular}{|c|c|c|c|c|}
\hline Especificação & 0 & 1 & 2 & 3 \\
\hline Recebimentos & & 36602063,52 & 38179859,46 & 39964687,43 \\
\hline Impostos sobre vendas & & 2690251,67 & 2806219,67 & 2937404,53 \\
\hline Valor residual de maq. e equip. & & & & 431318,54 \\
\hline Recebimentos liquidos & & 33911811,85 & 35373639,79 & 37027282,90 \\
\hline \multicolumn{5}{|l|}{ GASTOS } \\
\hline Custos fixos & & 10189210,45 & 10457008,99 & 10827462,69 \\
\hline Custos variáveis & & 18622796,69 & 19428921,27 & 20389328,79 \\
\hline Fundaçao & & 3983548,43 & 3983548,43 & 3983548,43 \\
\hline Colheita & & 8948410,12 & 9347868,56 & 9901609,93 \\
\hline Soqueira & & 5690838,15 & 6097504,29 & 6504170,43 \\
\hline Custo total & & 28812007,14 & 29885930,26 & 31216791,48 \\
\hline Lucro bruto & & 5099804,71 & 5487709,53 & 5810491,42 \\
\hline IR & & 866966,80 & 932910,62 & 987783,54 \\
\hline Depreciação & & 1105227,15 & 1105227,15 & 1105227,15 \\
\hline FCO & & 5338065,06 & 5660026,06 & 5927935,04 \\
\hline Inv. máq. e equip. & 3747000,00 & & & 3747000,00 \\
\hline Capital de giro & 9168282,67 & 14119176,64 & 14559130,98 & 15011942,23 \\
\hline Var capital de giro & 9168282,67 & 4950893,97 & 439954,34 & 452811,25 \\
\hline Fluxo de caixa líquido & $-12915282,67$ & 387171,09 & 5220071,72 & 1728123,78 \\
\hline
\end{tabular}

Fonte: Dados da pesquisa

\subsubsection{Reposição máquinas}

Para efeito de cálculo consideramos que a empresa adquire todos as máquinas e equipamentos novos no momento presente. Após 3 ( três ) períodos de depreciação os mesmos são substituídos por máquinas novas. $O$ valor residual é computado no item recebimentos.

\subsection{Empresa Industrial}

O parque industrial pode ser subdivido em departamentos, sendo o primeiro a recepção e moagem de cana, que é uma fase comum a produção 
de açúcar e álcool. A partir daí, o caldo obtido da extração da cana-de-açúcar pode ser direcionado a produção do açúcar, que passa a caracterizar o segundo departamento, ou a produção de álcool constituindo-se em outro departamento. Esses departamentos, necessitam de energia e vapor que são produzidos no departamento de suporte, ai incluindo-se, caldeiras, geradores e tratamento de efluentes. Ainda pode-se identificar o departamento de manutenção, as operações executadas em todo parque industrial. A administração e a comercialização dos produtos são executadas através do departamento de administração.

\subsubsection{Produção Industrial}

Com base nos dados apresentados no item formação de preços, incluindo o teor de ATR, o mix de produção industrial, e no item evolução da produção agrícola, projeta-se a produção de açúcar e álcool durante o horizonte de tempo da análise, apresentado no quadro 9 : 


\begin{tabular}{|c|c|c|c|}
\hline Produção Industrial & 1 & 2 & 3 \\
\hline Qtde. de cana em $t$ & 998350,00 & 1041385,62 & 1090068,21 \\
\hline Qtde. de ATR em kg & 145275055,54 & 151537390,80 & 158621444,45 \\
\hline Qtde de ATR em t & 145275,06 & 151537,39 & 158621,44 \\
\hline Qtde. de açúcar mercado interno & 5990,65 & 6248,89 & 6541,01 \\
\hline Qtde. de açúcar mercado externo & 47925,19 & 49991,09 & 52328,07 \\
\hline Qtde. de álcool anidro & 26406,00 & 27544,28 & 28831,92 \\
\hline Qtde. de álcool hidratado & 23386,36 & 24394,47 & 25534,86 \\
\hline Qtde.total de açúcar & 53915,84 & 56239,97 & 58869,07 \\
\hline Qtde. de alcool anidro direto & 23987,30 & 25021,31 & 26191,00 \\
\hline Qtde. de alcool anidro residual & 2418,71 & 2522,97 & 2640,92 \\
\hline Qtde. de alcool hidratado direto & 20862,06 & 21761,36 & 22778,66 \\
\hline Qtde. de alcool hidratado residual & 2524,30 & 2633,11 & 2756,21 \\
\hline Quant de prod. equiv em $t$ de ATR & 1 & 2 & 3 \\
\hline Quant. de AMI em ATR & 6287,19 & 6558,21 & 6864,79 \\
\hline Quant. de AME em ATR & 50297,49 & 52465,65 & 54918,30 \\
\hline Quant. de Aar em ATR & 4394,55 & 4583,99 & 4798,28 \\
\hline Quant. de AhR em ATR & 4394,55 & 4583,99 & 4798,28 \\
\hline Quant. de AaD em ATR & 43582,52 & 45461,22 & 47586,43 \\
\hline Quant. de Ahd em ATR & 36318,76 & 37884,35 & 39655,36 \\
\hline Total & 145275,06 & 151537,39 & 158621,44 \\
\hline Quant de prod em $t$ de cana & 1 & 2 & 3 \\
\hline Quant. de AMI em cana & 43206,40 & 45068,89 & 47175,76 \\
\hline Quant. de AME em cana & 345651,18 & 360551,08 & 377406,08 \\
\hline Quant. de AAr em cana & 30199,96 & 31501,78 & 32974,42 \\
\hline Quant. de Ahr em cana & 30199,96 & 31501,78 & 32974,42 \\
\hline Quant. de AaD em cana & 299505,00 & 312415,69 & 327020,46 \\
\hline Quant. de Ahd em cana & 249587,50 & 260346,41 & 272517,05 \\
\hline Total & & 998350,00 & $1041385,62 \quad 1090068,21$ \\
\hline
\end{tabular}

Quadro 9 - Produção da empresa industrial.

Fonte: Dados da pesquisa

\subsubsection{Dados Industriais}

Para o cálculo da depreciação e dos seguros é necessário a determinação do valor dos ativos correspondentes a cada departamento, a vida útil das máquinas, equipamentos e obras civis, assim como a alíquota de seguros. 
Tabela 13. Dados para cálculo de depreciação e seguros.

\begin{tabular}{lrccrr}
\hline \multicolumn{1}{c}{ Departamento } & Vr. inicial (un) & $\begin{array}{c}\text { Vida útil } \\
\text { anos }\end{array}$ & $\begin{array}{c}\text { Seguro } \\
\%\end{array}$ & Depreciação & Seguros \\
\hline Extração & 8000000,00 & 20,00 & 0,7 & 400000,00 & 56000 \\
Usina de Acuçar & 7000000,00 & 20,00 & 0,7 & 350000,00 & 49000 \\
Destilaria & 5000000,00 & 20,00 & 0,7 & 250000,00 & 35000 \\
Suporte & 13000000,00 & 20,00 & 0,7 & 650000,00 & 91000 \\
Manutenção & 1200000,00 & 20,00 & 0,7 & 60000,00 & 8400 \\
Total & 34200000,00 & & & 1710000,00 & 239400 \\
\hline
\end{tabular}

Fonte: Dados da pesquisa

\subsubsection{Demonstrativo de recebimentos e desembolsos}

Este item pode ser esquematizado da seguinte forma:

(+) Vendas de açúcar mercado interno

$(+)$ Vendas de açúcar mercado externo

(+) Vendas de açúcar mercado externo

$(+)$ Vendas de álcool hidratado

(=) Vendas de produtos

(+) Vendas de subprodutos

( - ) Impostos sobre vendas

(=) Total de Vendas Líquida

( - ) Despesas com matéria-prima

( - ) Depreciação

(-) Seguros

( - ) Custos de fabricação

Extração

usina de açúcar

destilaria

suporte

manutenção

( - ) Funcionários Produção 
( - ) Despesas Administrativas

( - ) Despesas de comercialização

Açúcar mercado interno

Açúcar mercado externo

Álcool

( - ) Reinvestimento

( - ) Capital de giro

No item recebimento, inclui-se a venda de produtos industrializados se subprodutos

\section{- Venda de produtos industriais}

A receita prevista de uma empresa do setor sucroalcooleiro pode ser obtido pela equação:

$$
R t=Q_{A M I} \cdot P_{A M I}+Q_{A M I} \cdot P_{M E}+Q_{A A R}+P_{A H}+Q_{A A D} \cdot P_{A A}+Q_{A H D} \cdot P_{A H}+Q_{i} \cdot P_{i}
$$

Onde:

$\mathrm{Rt}=$ Receita total;

$Q_{\text {AMI }}=$ Quantidade de açúcar no mercado interno;

$P_{\mathrm{AMI}}=$ Preço do açúcar no mercado interno;

$\mathrm{Q}_{\mathrm{AME}}=$ Quantidade do açúcar no mercado externo;

$\mathrm{P}_{\mathrm{ME}} \quad=$ Preço do açúcar no mercado externo;

$Q_{A A R}=$ Quantidade de álcool anidro residual;

$\mathrm{P}_{\mathrm{AA}}=$ Preço do álcool anidro;

$\mathrm{Q}_{\mathrm{AHR}}=$ Quantidade do álcool hidratado residual;

$P_{A H}=$ Preço do álcool hidratado; 
$Q_{A A D}=$ Quantidade de álcool anidro direto;

$Q_{A H D}=$ Quantidade de álcool hidratado direto;

Qi = Quantidade de subprodutos;

$P_{\mathbf{i}}=$ Preço de subprodutos.

\section{- Vendas de subprodutos}

No caso da usina em estudo são subprodutos a levedura para ração animal e o excesso de bagaço " in natura" para caldeiras industriais. Esse montante corresponde aproximadamente à $3 \%$ do valor das vendas totais.

\section{- Impostos e taxas sobre vendas}

Sobre as vendas incide impostos de PIS e COFINS, respectivamente, $0,65 \%$ e $3,20 \%$. Sobre o açúcar do mercado interno ICMS e IPI respectivamente $12 \%$ e $5 \%$. Sobre o álcool hidratado o ICMS do estado é $25 \%$ e de outros estados $7 \%$.

\section{- Despesas com matéria prima}

Referem-se aos gastos com cana de açúcar que podem ser de origem própria ou de fornecedores. No modelo utilizado considerou-se toda cana própria produzida em terras de terceiros e preços obtidos pelo método CONSECANA, uma vez que na avaliação de empresas estão sendo segmentados os negócios da área agrícola e industrial. 


\section{- Depreciação}

Como se pretende utilizar o valor presente líquido para aferir o valor da empresa o que interessa é o fluxo de caixa. No entanto, a depreciação é calculada para efeito de calculo do imposto de renda.

$$
D=\frac{V_{1}}{n}
$$

Onde:

$V_{1}=$ Valor de Reposição;

$n=$ Vida útil.

\section{- Seguros}

Os seguros são calculados segundo uma taxa obtida com seguradoras nacionais e computados sobre o valor dos ativos fixos da empresas.

$$
\operatorname{Seg}=V_{I} * \frac{s}{100}
$$

Onde

$S=$ Valor dos seguros;

$V_{I}=$ Valor de reposição;

$s=$ taxa seguros . 


\section{- Custos de fabricação}

Para calculo dos custos de fabricação segmentou-se a industria em cinco centros de custos apropriando-se em cada um deles gastos com materiais e insumos durante a safra.

\section{- Funcionários da produção}

Para cálculo do gastos com mão de obra segmentou-se os gastos na área de produção e área administrativa. Na área da produção computou-se os salários médios por centro de custo.

\section{- Despesas de comercialização}

Computou-se para o caso do açúcar do mercado interno despesas para embalagem e transporte da usina para o centro consumidor. Para o açúcar mercado externo, como o transporte é a granel, computou-se apenas transporte da usina até o Porto de Paranaguá/PR ou Porto de Santos/SP e os gastos com despesas portuárias até a elevação ao navio.

\section{- Reinvestimentos}

Uma empresa do setor sucroalcooleiro na região centro-sul, tem o período de safra definido entre abril à novembro. Após o término da safra os equipamentos industriais são totalmente desmontados e reformados, mantendo pois, a capacidade de produção. Estima-se um custo de $\mathrm{R} \$ 7.500 .000,00$ para a adequação da capacidade do parque industrial à meta de produção da empresa. Como despesas de manutenção de entresafra, que corresponde aos 
investimentos de reposição para manutenção da capacidade, a pesquisa de campo revela um valor de $\mathrm{R} \$ 2,50$ por tonelada de cana moída.

\section{- Capital de giro}

Um novo investimento de capital, em geral, aumenta o nivel das atividades da empresa representando acréscimo no ativo e passivo circulante.

O capital de giro, segundo LAPPONI (1996) pode ser definido como a diferença entre o ativo circulante e o passivo circulante. Segundo o autor o capital de giro pode ser obtido a partir do fluxo comercial do produto da seguinte forma.

Contas à receber: Definidas as vendas do período e o prazo de faturamento dessas vendas, obtém-se o valor que a empresa estará financiando por período. Com esses valores obtém-se o valor de giro necessário para a empresa financiar a venda de seus produtos.

Estoque mínimo de produtos acabados: Para atender as vendas a empresa necessita manter um estoque mínimo de produtos acabados. Nesses produtos acabados foram alocados recursos de matéria-prima, custos de mãode-obra e despesas gerais. Conhecido o volume do estoque mínimo de produto acabado e o valor unitário de todos os custos e despesas, obteremos o valor capital de giro referente ao estoque de produtos acabados.

Estoque de matérias primas: Para atender à produção é necessário manter um estoque mínimo de matérias primas. Conhecido o estoque e o valor das matérias primas e o valor dos produtos em processo obteremos o valor de capital de giro necessário para manter o estoque de matérias primas. Como em geral o fornecedor das matérias primas fatura sua 
venda, por exemplo: para 30,60, 90 ou mais dias, a empresa estará recebendo do fornecedor um financiamento sem nenhum custo aparente; portanto, o valor do capital de giro total será diminuído deste valor.

Produtos em processo: Como o processo de produção não é instantâneo, isto é, existe um determinado tempo de processo para obter uma unidade de produto, recursos de matéria-prima e despesas de mão-de-obra e gerais são alocados nesses produtos em processo. Desses valores obtém o valor de capital de giro necessário para manter os produtos em processo.

Numa indústria sucroalcooleira, pela características da sazonalidade de produção (concentrada de maio a novembro), e de gastos com manutenção de entresafra (depreciado) a necessidade de capital de giro deve ser calculada separando-a nos dois períodos.

$C G_{\text {ind }}=\frac{\text { Vend }:{ }^{*} n_{1}+\left(\text { Desp }_{M P}+\text { Seg } .+ \text { Custo }_{\text {Fab }}+\text { func }_{\text {prod }}+\operatorname{desp}_{\text {adm }}\right) *\left(n_{2}+n_{3}\right)+\operatorname{Desp}_{M P}\left(n_{4}-n_{5}\right)}{360}$

Onde:

$C G_{\text {ind }}=$ Capital de giro da indústria;

Vend.$=$ Vendas no periodo;

$n_{1}=$ Prazo de faturamento;

$\operatorname{Desp}_{M P}=$ Despesas com matéria-prima;

Seg. $=$ Despesas com seguros;

Custo $_{F a b}=$ Custos de fabricação;

func $_{\text {prod }}=$ Funcionários da produção;

$d e s p_{a d m}=$ Despesas administrativas;

$n_{2}=$ Dias de estoque de produtos acabados;

$n_{3}=$ Dias de processo; 


$$
\begin{aligned}
& n_{4}=\text { Número de diasd de estoque de matéria-prima; } \\
& n_{5}=\text { Prazo de pagamento à fornecedores de matéria-prima } .
\end{aligned}
$$

Os dados consolidados de recebimentos e desembolsos podem ser visualizados na tabela 14. Esses valores foram obtidos a partir dos dados básicos apresentados no anexo.

Tabela 14. Demonstrativos de recebimentos e desembolsos.

\begin{tabular}{lrrrr}
\hline \multicolumn{1}{c}{ Período } & \multicolumn{1}{c}{1} & \multicolumn{1}{c}{2} & \multicolumn{1}{c}{3} \\
\hline Vendas de açúcar mercado interno & 3869958,98 & 4036780,33 & 4225491,30 \\
Vendas de açúcar mercado externo & 26925715,31 & 28086395,35 & 29399375,14 \\
Vendas de álcool anidro & 19804502,96 & 20658210,69 & 21623938,50 \\
Vendas de álcool hidratado & 15902725,45 & 16588240,24 & 17363705,51 \\
Vendas de produtos & 66502903 & 69369627 & 72612510 \\
Vendas de subprodutos & 1995087 & 2081089 & 2178375 \\
Impostos sobre vendas & 4614105 & 4813004 & 5038002 \\
Total de Vendas Liquida & 63883885 & 66637711 & 69752884 \\
Despesas com matéria-prima & 36602064 & 38179859 & 39964687 \\
Depreciação & 1710000 & 1710000 & 1710000 \\
Seguros & 239400 & 239400 & 239400 \\
Custos de fabricação & 1899692 & 1981582 & 2074216 \\
$\quad$ Extração & 546877 & 570451 & 597118 \\
$\quad$ usina de açúcar & 194409 & 202789 & 212269 \\
$\quad$ Destilaria & 318086 & 331798 & 347309 \\
$\quad$ Suporte & 746038 & 778197 & 814576 \\
$\quad$ Manutenção & 94282 & 98346 & 102944 \\
Funcionários Produção & 1758240 & 1758240 & 1758240 \\
Despesas Administrativas & 3107360 & 3176217 & 3254109 \\
Despesas de comercialização & 6982722 & 7283724 & 7624223 \\
\multicolumn{1}{c}{ Açúcar mercado interno } & 327346 & 341457 & 357419 \\
Açúcar mercado externo & 4539200 & 4734870 & 4956215 \\
$\quad$ Álcool & 2116176 & 2207397 & 2310588 \\
Reinvestimento & 2500000 & 2500000 & 2500000 \\
Capital de giro & 6532322 & 6801309 & 7105592 \\
\hline
\end{tabular}

Fonte: Dados da pesquisa 


\subsubsection{Valor da indústria}

Neste item é estruturado o fluxo de caixa líquido da empresa nos diversos anos definidos no horizonte de tempo característico do ciclo de negócios do setor sucroalooleiro. Esse fluxo descontado a uma determinada taxa de juros corresponderá ao Valor Presente Líquido da empresa. Para a obtenção desse fluxo de caixa, são utilizados valores obtidos no item recebimentos e desembolsos e consolidados no demonstrativo a seguir:

Demonstrativo de resultado

$(+)$ Vendas

( - ) Impostos sobre vendas

( =) Vendas líquida

( - ) Matéria-prima

( - ) Despesas de comercialização

(-) Despesas industriais

$(=)$ Lucro bruto

( - ) Despesas administrativas

( =) $\mathrm{LO}=\mathrm{EBIT}$

(-) IR

(=) Lucro Líquido

(+) Depreciação

( - ) Reinvestimento

(+/-) Variação no capital de giro

( =) Fluxo de Caixa Líquido da Empresa

Com os dados obtidos no item recebimento e desembolso, podese calcular o fluxo de caixa líquido apresentado na tabela 15. 
Tabela 15. Estruturação do fluxo de caixa líquido da empresa industrial.

\begin{tabular}{|c|c|c|c|c|}
\hline Período & 0 & 1 & 2 & 3 \\
\hline \multicolumn{5}{|l|}{ Demonstrativo de resultado } \\
\hline Vendas & & 66502902,71 & 69369626,60 & 72612510,45 \\
\hline Impostos sobre vendas & & 4614104,91 & 4813003,97 & 5038001,76 \\
\hline Vendas liquida & & 61888797,80 & 64556622,63 & 67574508,68 \\
\hline Matéria-prima & & 36602063,52 & 38179859,46 & 39964687,43 \\
\hline Despesas de comercialização & & 6982721,67 & 7283724,10 & 7624222,85 \\
\hline Despesas industriais & & 5607332,03 & 5689221,57 & 5781856,34 \\
\hline Lucro bruto & & 12696680,58 & 13403817,50 & 14203742,07 \\
\hline Despesas administrativas & & 3107360,00 & 3176217,00 & 3254109,13 \\
\hline Juros s capital de giro & & 0,00 & 0,00 & 0,00 \\
\hline $\mathrm{LO}=\mathrm{EB} \mid \mathrm{T}$ & & 9589320,58 & 10227600,50 & 10949632,94 \\
\hline $\mathrm{IR}$ & & 1630184,50 & 1738692,09 & 1861437,60 \\
\hline Lucro Líquido & & 7959136,08 & 8488908,42 & 9088195,34 \\
\hline Deprec & & 1710000,00 & 1710000,00 & 1710000,00 \\
\hline Reinvestimento & 7500000 & 2500000,00 & 2500000,00 & 2500000,00 \\
\hline Variação no capital de giro & & 6532322,49 & 268986,94 & 304282,32 \\
\hline Fluxo de Caixa Líq. da Empresa & $-7500000,00$ & 636813,59 & 7429921,48 & 7993913,03 \\
\hline
\end{tabular}

Fonte: Dados da pesquisa

\subsubsection{Projeção de desempenho}

Nesta fase é realizada a projeção no período de tempo considerado para o cálculo do Valor Econômico da Empresa, levando-se em consideração os dados históricos e os previstos a partir da posição estratégica que a empresa assume na indústria em que está inserida. Serão desenvolvidos cenários de desempenho caracterizando situações pessimistas, mais prováveis e otimistas.

\subsubsection{Estimação do custo capital}

Neste trabalho a taxa de desconto pode ser referenciada às taxas de depósitos interbancários (CDI), títulos públicos, SELIC, e a remuneração da caderneta de poupança como indicadores financeiros que comporão o custo de capital. Como os fluxos de caixa são calculados a preços constantes, essas 
taxas devem ser deflacionadas por um indice de preços a ser escolhido entre IPCA, calculado pelo IBGE ou IGP-M, calculado pela Fundação Getúlio Vargas.

Tabela 16. Indicadores Financeiros no período de set/99 à set/02.

\begin{tabular}{lccc}
\hline Indices & Ultimos 12 meses & Ultimos 24 meses & Ultimos 36 meses \\
\hline CDI & 18,42 & 38,03 & 62,96 \\
IBX (MÉDIO) & $-0,72$ & $-19,44$ & 19,43 \\
POUPANÇA & 8,90 & 17,87 & 28,25 \\
IGP-M & 13,32 & 23,61 & 42,23 \\
CDI-REAL & 4,50 & 11,67 & 14,57 \\
\hline
\end{tabular}

Fonte: Relatório Banco Itaú

* Taxa de CDI deflacionada pelo IGP-M.

\subsubsection{Estimação valor perpétuo}

O valor da perpetuidade como foi visto vem a ser o Valor Presente do Fluxo de Caixa depois do período de projeção explícita. A estimativa do Valor da Perpetuidade é um processo de quatro etapas:

- Selecionar uma técnica apropriada;

- Decidir qual será o horizonte projetado;

- Estimar os parâmetros da avaliação;

- Avaliação em condições de risco.

No trabalho serão comparados diversos períodos de análise, com horizonte de tempo bastante longo, eliminando a necessidade de se calcular o valor da perpetuidade. 


\section{RESULTADOS E DISCUSSÃO}

A implementação do modelo de avaliação em software Excel permite aos interessados realizarem simulações a medida que se alterem os parâmetros técnicos e econômicos considerados. A tabela 17 é construída com os dados do anexo, que possuem os seguintes valores:

Preço álcool hidratado $\mathrm{R} \$ / \mathrm{m} 3 \quad 680$

Preço álcool anidro $\mathrm{R} \$ / \mathrm{m} 3 \quad 750$

Preço açúcar mercado externo U\$ib $\quad 7,2$

Preço açúcar mercado interno U\$/sc $\quad 9,5$

Taxa de câmbio $\quad 3,4$

POL $\quad 15,12$

$\begin{array}{ll}\text { Pureza } & 87,7\end{array}$

Fibra $\quad 12,65$

Rendimento de processo $\quad 0,88$

Produtividade agrícola corte $1 \mathrm{t} / \mathrm{ha} \quad 117$

Produtividade agrícola corte 2 tha $\quad 100$

Produtividade agrícola corte 3 t/ha 84

Produtividade agrícola corte 4 tha $\quad 70$

Produtividade agrícola corte 5 t/ha $\quad 68$

Produtividade agrícola corte 6 t/ha $\quad 60$

Produtividade agrícola corte 7 tha 0

Horizonte de tempo (anos) 70

Meta de produção em toneladas $\quad 1200000$ 
Pode-se concluir com esses dados que, o valor presente líquido obtido quando se utiliza, por exemplo, a taxa de desconto de 10\%a.a. é de $R \$ 107432$ mil, sendo que o valor da empresa agrícola representa $R \$ 35114$ mil, e a empresa industrial $\mathrm{R} \$ 72317$ mil. Este será o valor referencial para eventual negociação acionária, considerando-se uma empresa sem dívidas. Como já salientado, desse valor deve-se subtrair o valor líquido das dívidas da empresa. A taxa de desconto considerada depende do custo de oportunidade requerido pelo comprador. A medida que este custo aumente, o valor presente diminui alterando o valor referencial, por exemplo, para $\mathrm{R} \$ 74416$ mil considerando-se uma taxa de desconto de $13 \%$.

A anualização do valor presente com a taxa de desconto escolhida, por exemplo, $10 \%$ a.a. estima valores moretários anuais de $\mathrm{R} \$ 3516$ mil para a empresa agrícola e $\mathrm{R} \$ 7241$ mil para a industrial.

Tabela 17. Valor da empresa e taxa de juros.

\begin{tabular}{|c|c|c|c|c|c|}
\hline \multirow[t]{2}{*}{ Taxa de juros } & \multicolumn{3}{|c|}{$\begin{array}{c}\text { Valor presente líquido } \\
\mathrm{R} \$(\text { mil) }\end{array}$} & \multicolumn{2}{|c|}{$\begin{array}{c}\text { Valor uniforme líquid } \\
\mathrm{R} \$(\mathrm{mil})\end{array}$} \\
\hline & agrícola & indústria & Total & agrícola & indústria \\
\hline 0,05 & 86778 & 157023 & 243801 & 4486 & 8118 \\
\hline 0,06 & 70369 & 130145 & 200514 & 4295 & 7943 \\
\hline 0,07 & 58064 & 109978 & 168043 & 4100 & 7767 \\
\hline 0,08 & 48591 & 94442 & 143033 & 3905 & 7590 \\
\hline 0,09 & 41124 & 82187 & 123310 & 3710 & 8219 \\
\hline 0,1 & 35114 & 72317 & 107432 & 3516 & 7241 \\
\hline 0,11 & 30190 & 64223 & 94414 & 3323 & 7069 \\
\hline 0,12 & 26091 & 57479 & 83571 & 3132 & 6900 \\
\hline 0,13 & 22632 & 51783 & 74416 & 2943 & 6733 \\
\hline
\end{tabular}

Fonte: Dados da pesquisa

A figura 4 mostra graficamente o comportamento do valor presente liquido a medida que se altera a taxa de desconto: 


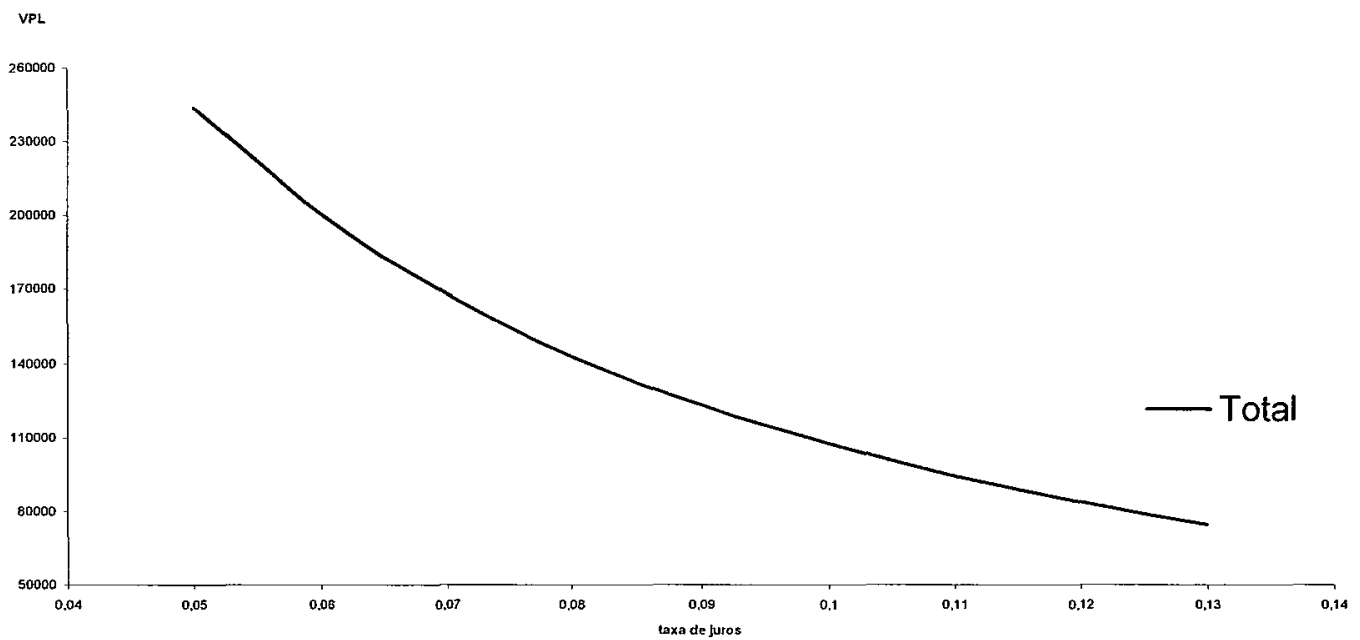

Figura 4 - Comportamento do valor presente líquido em relação a taxa de juros.

Fonte: Dados da pesquisa

Com os mesmos parâmetros já citados mas, simulando-se com diversos horizontes de tempo pode-se constatar que quando maior este período e maior a taxa de desconto requerida, menor será a variação do valor presente líquido, conforme tabela 18 e figura 5 . Esses resultados sugerem que horizontes de 40 à 50 anos são adequados à mensuração do valor de empresas do setor sucroalcooleiro. 
Tabela 18. Valor da empresa taxa de juros e horizonte de tempo em $\mathrm{R} \$$ (mil)

\begin{tabular}{crrrrrr}
\hline \multirow{2}{*}{ Taxa de juros } & \multicolumn{7}{c}{ horizonte de tempo } \\
\cline { 2 - 7 } & \multicolumn{1}{c}{30} & \multicolumn{1}{c}{ 35 } & \multicolumn{1}{c}{50} & \multicolumn{1}{c}{ 50 } & \multicolumn{1}{c}{70} \\
\hline 0,05 & 184962 & 200240 & 211591 & 227879 & 237639 & 243800 \\
0,06 & 161666 & 172852 & 180774 & 191370 & 197187 & 200514 \\
0,07 & 142055 & 150270 & 155819 & 162780 & 166235 & 168043 \\
0,08 & 125436 & 131489 & 135388 & 139971 & 142044 & 143033 \\
0,09 & 111263 & 115735 & 118485 & 121516 & 122766 & 123310 \\
0,1 & 99099 & 102413 & 104359 & 106372 & 107130 & 107432 \\
0,11 & 88596 & 91059 & 92440 & 93784 & 94246 & 94414 \\
0,12 & 79474 & 81310 & 82294 & 83194 & 83477 & 83571 \\
0,13 & 71507 & 72879 & 73582 & 74188 & 74362 & 74415 \\
\hline
\end{tabular}

Fonte: Dados da pesquisa

$$
\text { Valor Presente }
$$

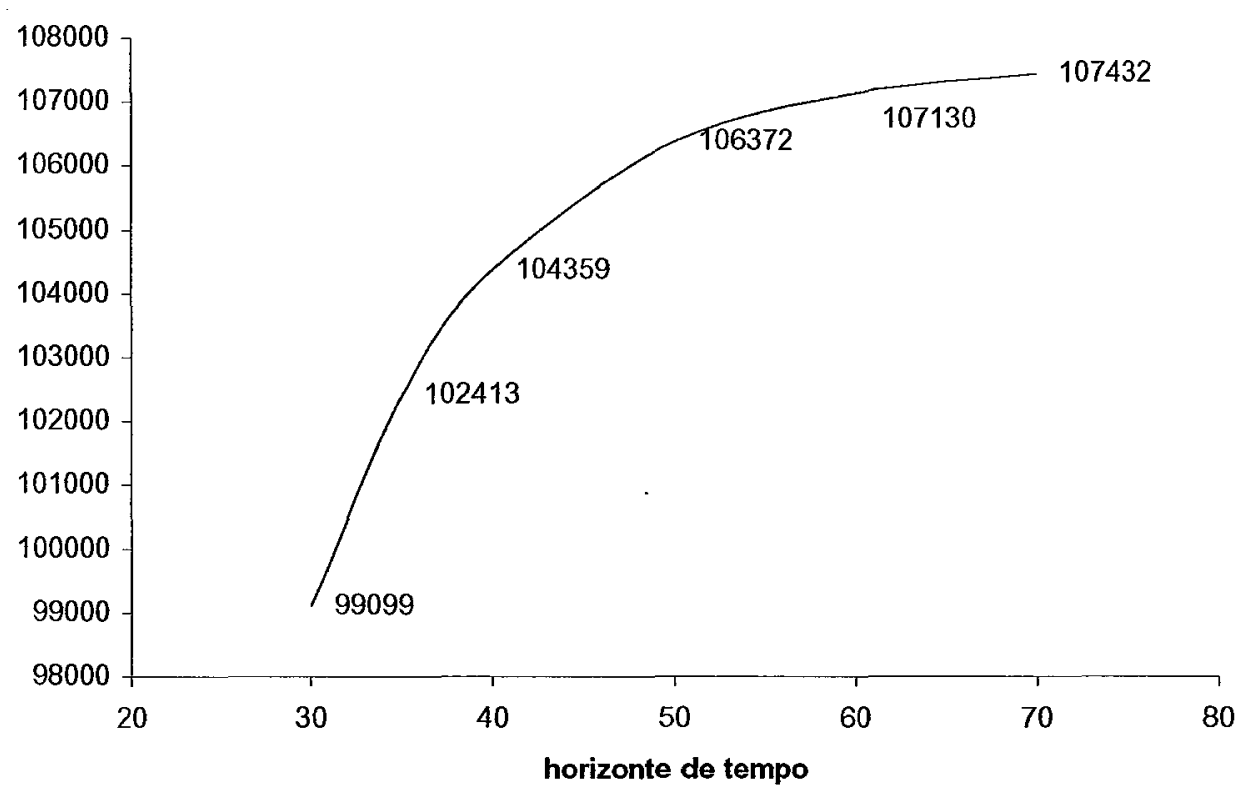

Figura 5 - Comportamento do valor presente líquido em relação ao horizonte de tempo.

Fonte: Dados da pesquisa

Sendo o setor sucroalcooleiro exportador de açúcar, a política cambial tem especial importância na valorização das empresas, pois alterações 
cambiais fazem com que os emrpresários, aumentem ou diminuam as exportações, alterando o fluxo de caixa das empresas, quando se contabiliza essas transações em moeda nacional. É importante também analisar o impacto do câmbio nos custos de produção, uma vez muitos insumos utilizados no setor são atrelados a moedas externas. Para isso o modelo vincula diversas rubricas de custos, a mudanças na taxa de câmbio. Na tabela 19, obtem-se os valores presentes líquidos dos fluxos de caixa quando se alteram taza de câmbio e taxa de juros simultaneamente. Nota-se que para uma taxa de câmbio de 2,6 e para uma taxa de juros de $10 \%$ o valor presente e de $\mathrm{R} \$ 94213$ mil comparado com $\mathrm{R} \$ 107432$ mil para a taxa de câmbio de 3,4 .

Tabela 19. Valor da empresa e taxa de câmbio.

\begin{tabular}{crrrrr}
\hline \multirow{2}{*}{ taxa de juros } & \multicolumn{5}{c}{$\begin{array}{c}\text { taxa de câmbio } \\
\text { R\$ (mil) }\end{array}$} \\
\cline { 2 - 6 } & \multicolumn{1}{c}{2,6} & 2,8 & \multicolumn{1}{c}{3} & \multicolumn{1}{c}{3,2} & \multicolumn{1}{c}{3,4} \\
\hline 0,05 & 214722 & 221992 & 229261 & 236531 & 243800 \\
0,06 & 176470 & 182481 & 188492 & 194503 & 200514 \\
0,07 & 147754 & 152842 & 157909 & 162976 & 168043 \\
0,08 & 125674 & 130014 & 134353 & 138693 & 143032 \\
0,09 & 108245 & 112011 & 115778 & 119544 & 123310 \\
0,1 & 94213 & 97518 & 100823 & 104127 & 107432 \\
0,11 & 82709 & 85635 & 88562 & 91488 & 94414 \\
0,12 & 73128 & 77738 & 78349 & 80960 & 83571 \\
0,13 & 65037 & 67381 & 69726 & 72070 & 74415 \\
\hline
\end{tabular}

Fonte: Dados da pesquisa

A produtividade agrícola é um dos principais parâmetros que influenciam o valor presente e, conseqüentemente o valor da empresa. Assim simulando-se os cálculos para um cenário otimista, o valor da empresa passa a ser $\mathrm{R} \$ 130707$ mil comparados com $\mathrm{R} \$ 107432$ mil, no cenário considerado de produtividade normal. A tabela 20 mostra os diversos valores considerando-se a produtividade otimista e as diversas taxas de juros.

Como produtividade otimista considerou-se os seguintes parâmetros em toneladas de cana de açúcar/ha : 


$\begin{array}{lr}1^{0} \text { corte } & 128,7 \\ 2^{\circ} \text { corte } & 110,0 \\ 3^{\circ} \text { corte } & 92,4 \\ 4^{\circ} \text { corte } & 77,0 \\ 5^{\circ} \text { corte } & 74,8 \\ 6^{\circ} \text { corte } & 66,0\end{array}$

Tabela 20. Valor da empresa considerando a produtividade de cana de açúcar otimista.

\begin{tabular}{crrr}
\hline Taxa de & \multicolumn{3}{c}{$\begin{array}{c}\text { Valor presente líquido } \\
\text { R } \$ \text { (mil) }\end{array}$} \\
\cline { 2 - 4 } juros & Agrícola & Indüstria & total \\
\hline 0,05 & 124544 & 159737 & 284281 \\
0,06 & 102847 & 132780 & 235627 \\
0,07 & 86550 & 112537 & 199087 \\
0,08 & 73978 & 96927 & 170906 \\
0,09 & 64049 & 84603 & 148652 \\
0,1 & 56040 & 74667 & 130707 \\
0,11 & 49461 & 66509 & 115971 \\
0,12 & 43971 & 59705 & 103676 \\
0,13 & 39325 & 53950 & 93275 \\
\hline
\end{tabular}

Fonte: Dados da pesquisa

Num cenário pessimista por outro lado, o valor da empresa cai para $\mathrm{R} \$ 80450$ mil, confome verificado na tabela 21 , considerando-se os seguintes parâmetros de produtividade agrícola em toneladas de cana de açúcar / ha.

$\begin{array}{ll}1^{0} \text { corte } & 105,3 \\ 2^{\circ} \text { corte } & 90,0 \\ 3^{0} \text { corte } & 75,6 \\ 4^{\circ} \text { corte } & 63,0 \\ 5^{\circ} \text { corte } & 61,2 \\ 6^{\circ} \text { corte } & 54,0\end{array}$


Tabela 21. Valor da empresa com produtividade agricola pessimista.

\begin{tabular}{cccc}
\hline & \multicolumn{3}{c}{$\begin{array}{c}\text { Valor presente líquido } \\
\mathrm{R} \$(\mathrm{mil})\end{array}$} \\
\cline { 2 - 4 } Taxa de juros & agrícola & Indústria & total \\
\hline 0,05 & 41504 & 154309 & 195813 \\
0,06 & 31592 & 127511 & 159102 \\
0,07 & 24186 & 107420 & 131605 \\
0,08 & 18506 & 91956 & 110462 \\
0,09 & 14051 & 79770 & 93821 \\
0,1 & 10483 & 69967 & 80450 \\
0,11 & 7575 & 61937 & 69512 \\
0,12 & 5168 & 55254 & 60422 \\
0,13 & 3149 & 49617 & 52765 \\
\hline
\end{tabular}

Fonte: Dados da pesquisa

Por outro lado, quando se constrói novos cenários onde preços possam variar, conforme tabela 21 , pode-se constatar na tabela 22 , que a uma taxa de $10 \%$ a.a., num ambiente otimista, o valor presente será de $\mathrm{R} \$ 184047$ mil, caindo para $\mathrm{R} \$ 82735$ mil num ambiente pessimista de preços.

Tabela 22. Cenários de preços.

\begin{tabular}{lrlr}
\hline Cenário & Otim & Nomal & Pess \\
\hline Açúca mercado externo (ct.U\$/lb) & & & \\
Açúcar mercado interno (U\$/sc) & 7,92 & 7,2 & 6,48 \\
Álcool anidro $\left(\mathrm{R} \$ \mathrm{~m}^{3}\right)$ & 8,45 & 9,5 & 8,55 \\
Álcool hidratado $\left(\mathrm{R} \$ \mathrm{~m}^{3}\right)$ & 748 & 750 & 675 \\
\hline
\end{tabular}

Fonte: Dados da pesquisa 
Tabela 23. Valor da empresa e preços dos produtos.

\begin{tabular}{cccc}
\hline & \multicolumn{3}{c}{$\begin{array}{c}\text { Valor presente líquido } \\
\text { R\$ (mil) }\end{array}$} \\
\cline { 2 - 4 } taxa de juros & otimista & nomal & pessimista \\
\hline 0,05 & 389740 & 243801 & 190628 \\
0,06 & 324593 & 200514 & 156426 \\
0,07 & 275658 & 168043 & 130749 \\
0,08 & 237910 & 143033 & 110954 \\
0,09 & 208094 & 123310 & 95328 \\
0,1 & 184047 & 107432 & 82735 \\
0,11 & 164293 & 94414 & 72399 \\
0,12 & 147808 & 83571 & 63780 \\
0,13 & 133858 & 74416 & 56493 \\
\hline
\end{tabular}

Fonte: Dados da pesquisa 


\section{CONCLUSÕES}

A partir da década de 1990, o setor sucroalcooleiro passou a atuar num ambiente de livre mercado, sendo que mais de 30 (trinta) fusões e aquisições aconteceram como forma de adaptação à estrutura de comercialização existente neste mercado.

Mesmo com este número de transações acionárias, há espaco para novos negócios, inclusive com a maior participação de capital externo.

Entre os diversos métodos de avaliação econômica, o que utiliza o valor presente líquido é adequado para mensurar o valor empresas do setor sucroalcooleiro.

O método do valor presente líquido tem o respaldo da teoria econômica, em estudos que se referenciam em Modigliani e Miller.

A partir de pesquisa de campo realizada junto a uma empresa de porte médio, e que produz açúcar e álcool, construiu-se um modelo que utiliza os parâmetros técnicos e econômicos que influenciam no fluxo de caixa, implementando-o em software Excel.

Considerando-se que a construção do fluxo de caixa é estruturada, com base em dados previstos, o modelo permite simulações com cenários alternativos, permitindo a visualização dos possiveis valores que uma 
empresa pode assumir, quando da mudança dos parâmetros técnicos e econômicos.

Os valores obtidos são indicativos, sendo que os valores finais de negociação dependerão do resultado de negociações dadas as posições assimétricas que compradores e vendedores assumem. 
ANEXO:

Coletânea de planilhas que compõe o modelo de avaliação de empresa 


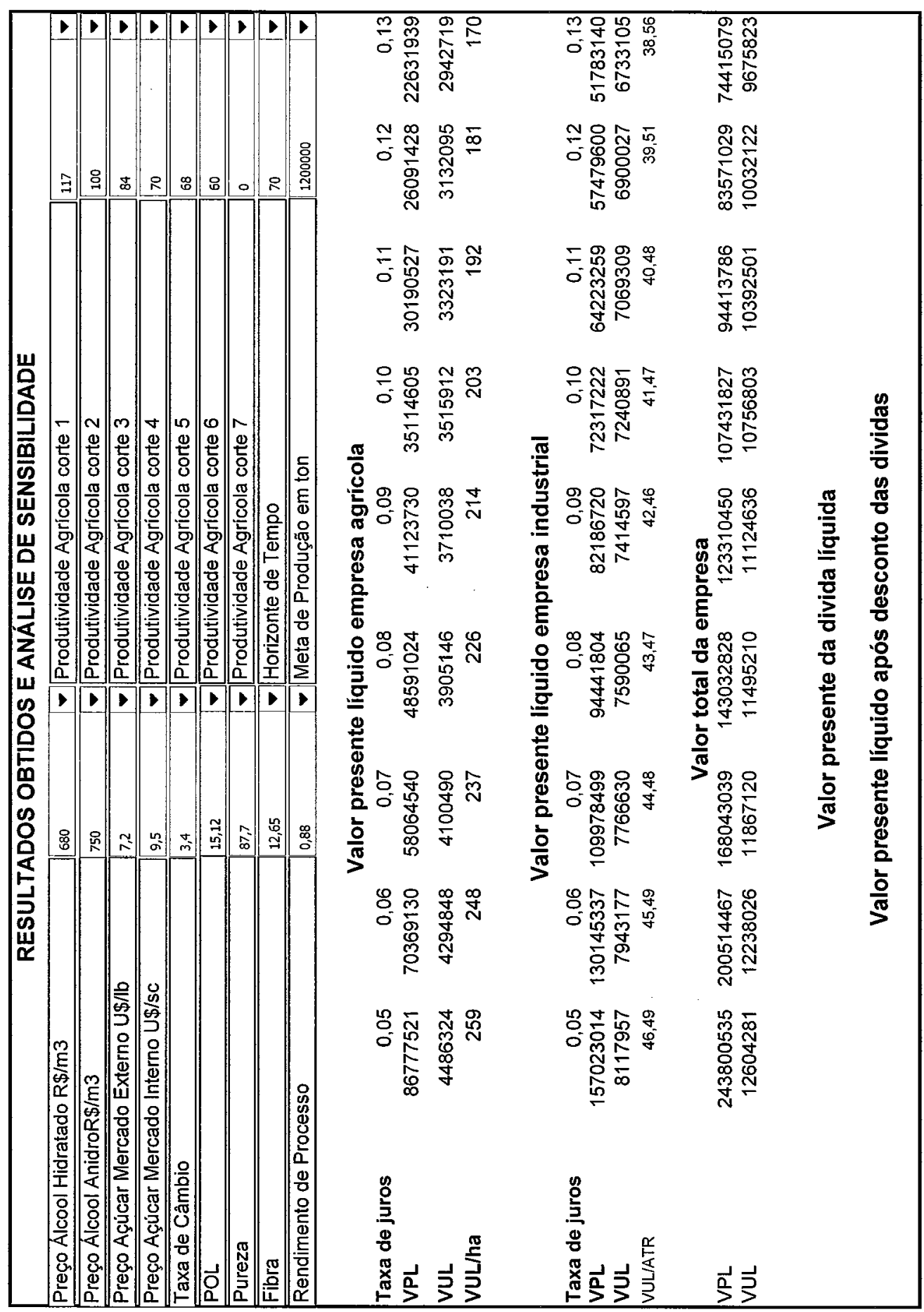




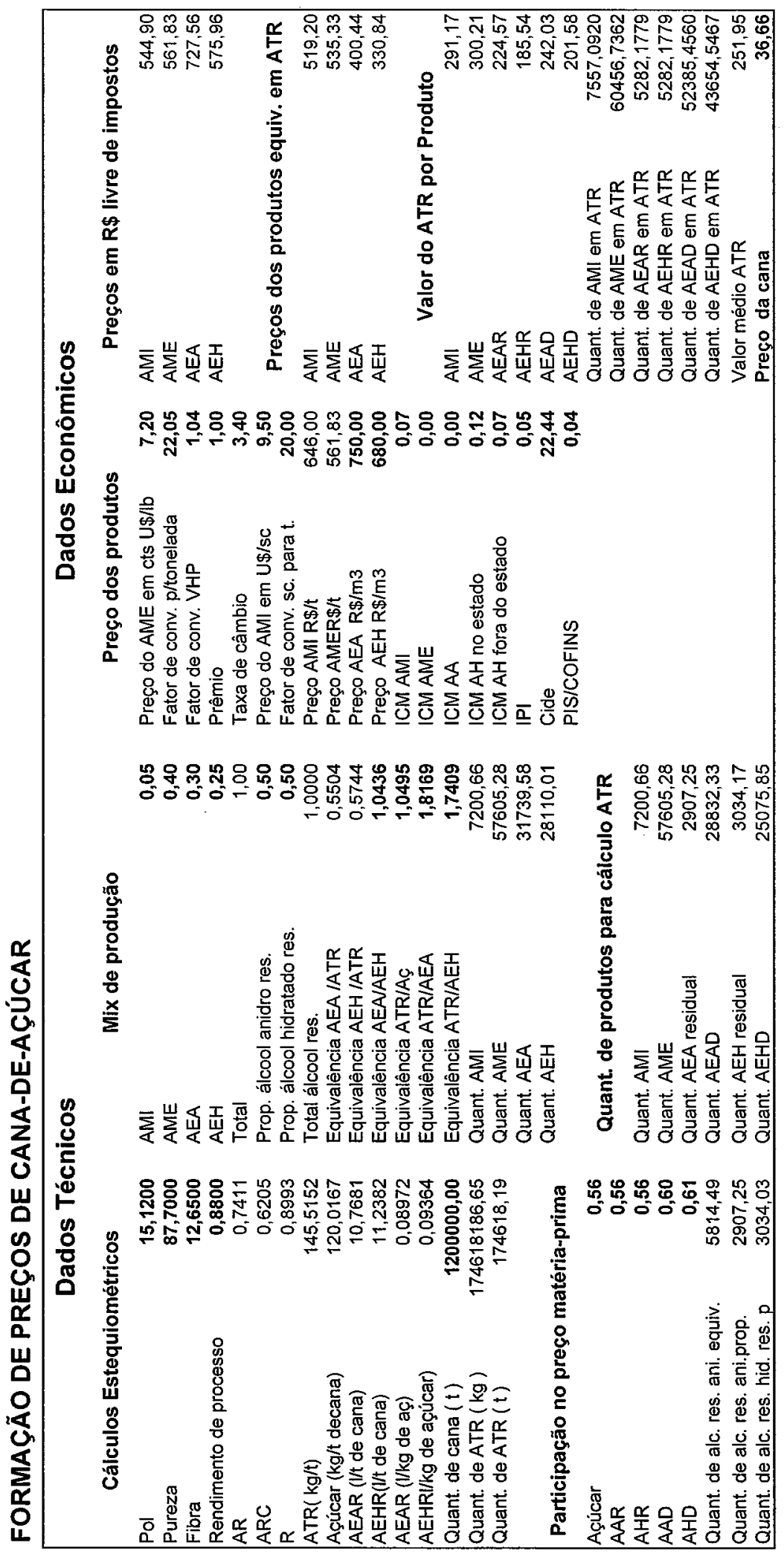




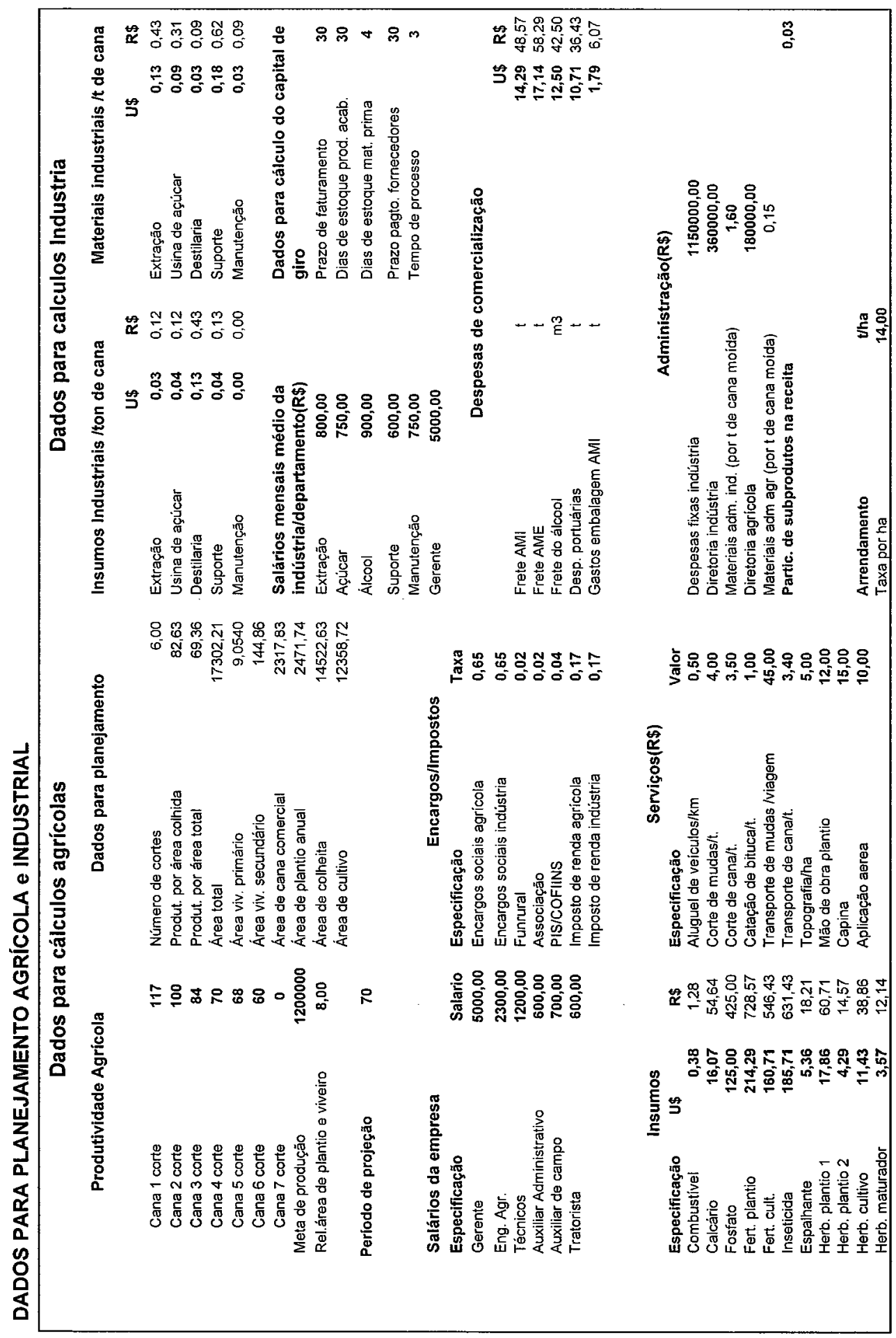




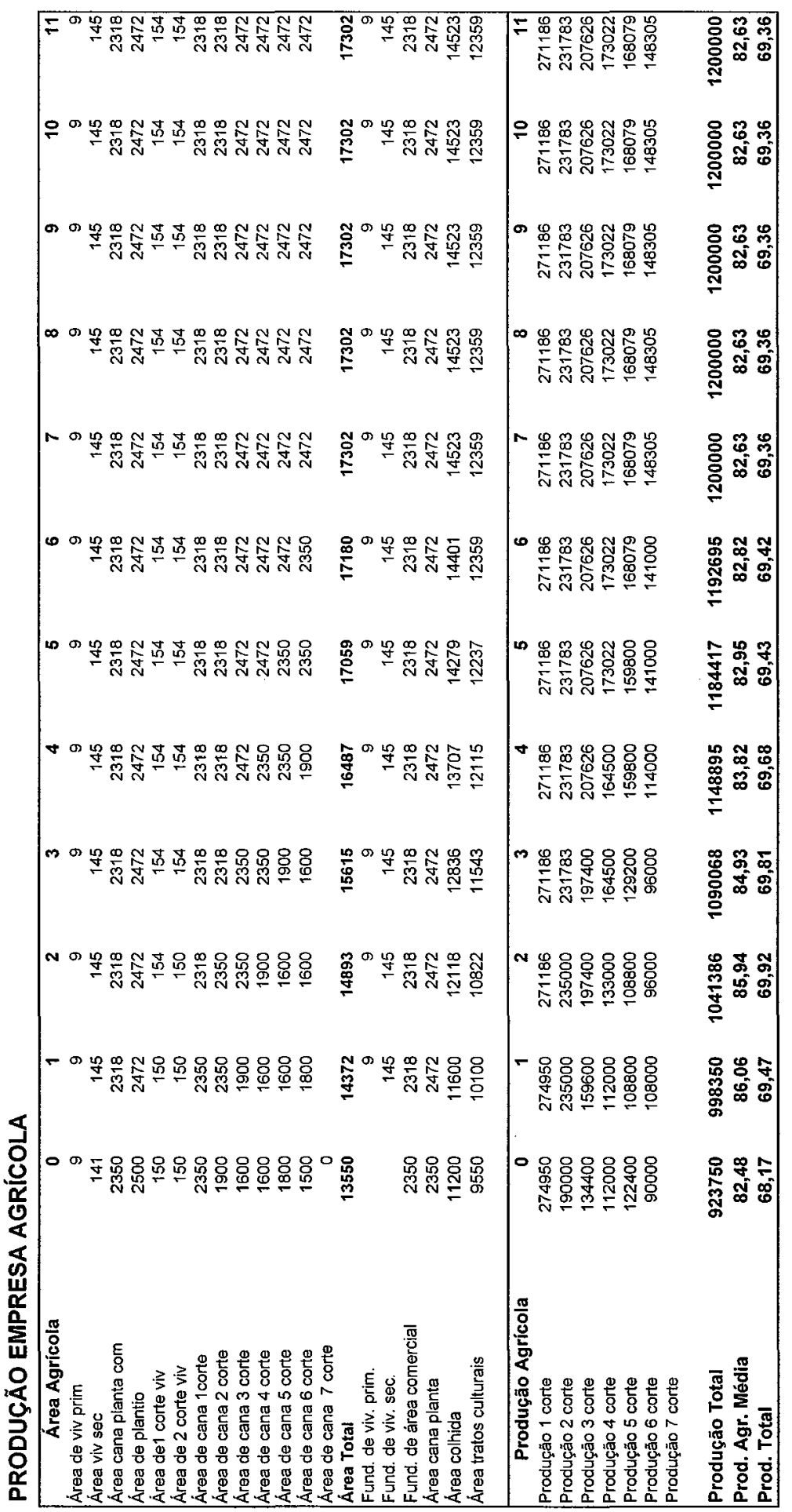




\begin{tabular}{|c|c|c|c|}
\hline & 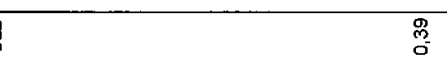 & $\stackrel{\text { do }}{g}$ & 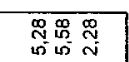 \\
\hline & 洄 & 象总总 & 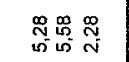 \\
\hline & 总 & 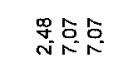 & 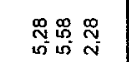 \\
\hline & ; & 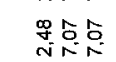 & 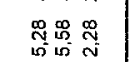 \\
\hline & & 总总 & 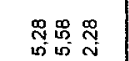 \\
\hline & & 管总 & 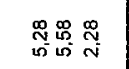 \\
\hline & 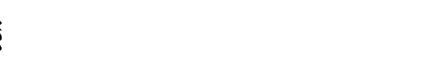 & 筫总 & 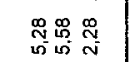 \\
\hline & 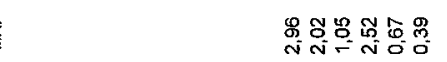 & 筫总 & 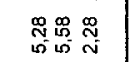 \\
\hline & 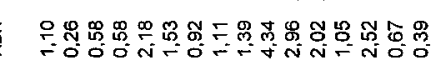 & 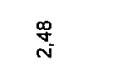 & \\
\hline & 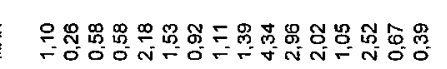 & $\underset{\substack{q \\
\text { s }}}{2}$ & \\
\hline & 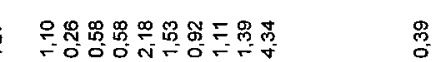 & 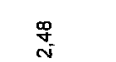 & \\
\hline & int & 票 & \\
\hline & 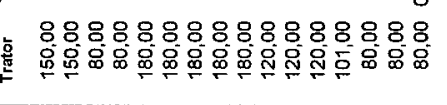 & - & 兽: \\
\hline \multirow{12}{*}{ 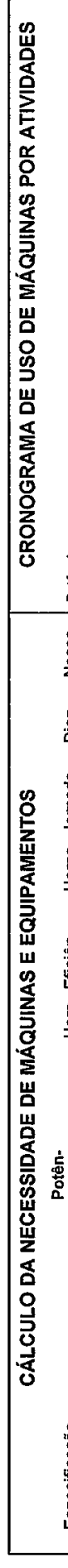 } & 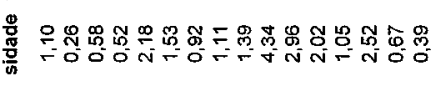 & $\stackrel{\text { Tog }}{N}$ & 趈总 \\
\hline & 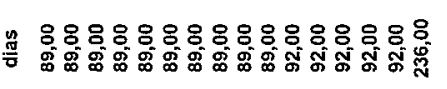 & 总: & 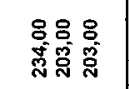 \\
\hline & 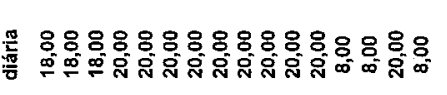 & 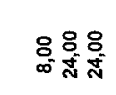 & 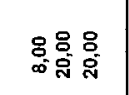 \\
\hline & 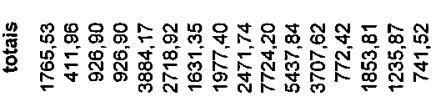 & 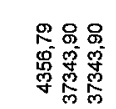 & 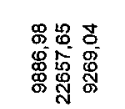 \\
\hline & 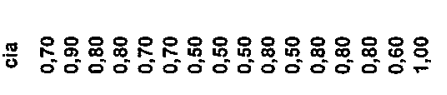 & 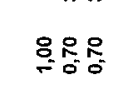 & 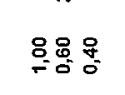 \\
\hline & 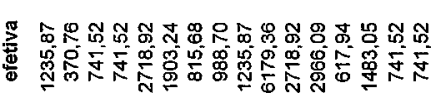 & 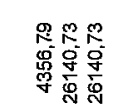 & 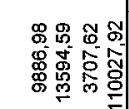 \\
\hline & 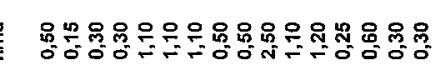 & 尊哭品 & 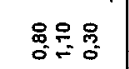 \\
\hline & 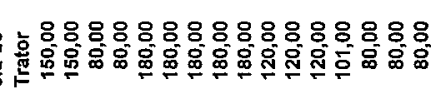 & 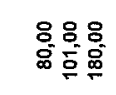 & 음윰 \\
\hline & 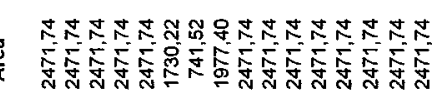 & 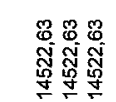 & 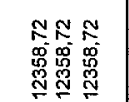 \\
\hline & 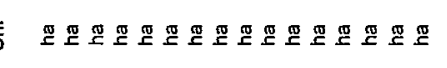 & 또 또 & 또 또 \\
\hline & 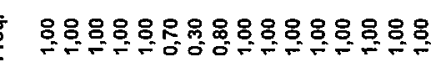 & $8: 8$ & 옹욤 \\
\hline & 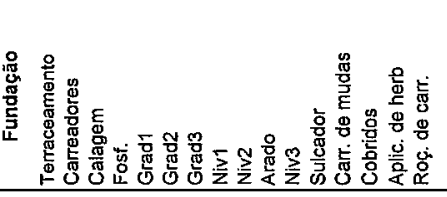 & 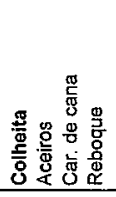 & 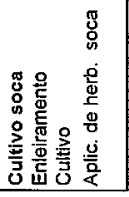 \\
\hline
\end{tabular}




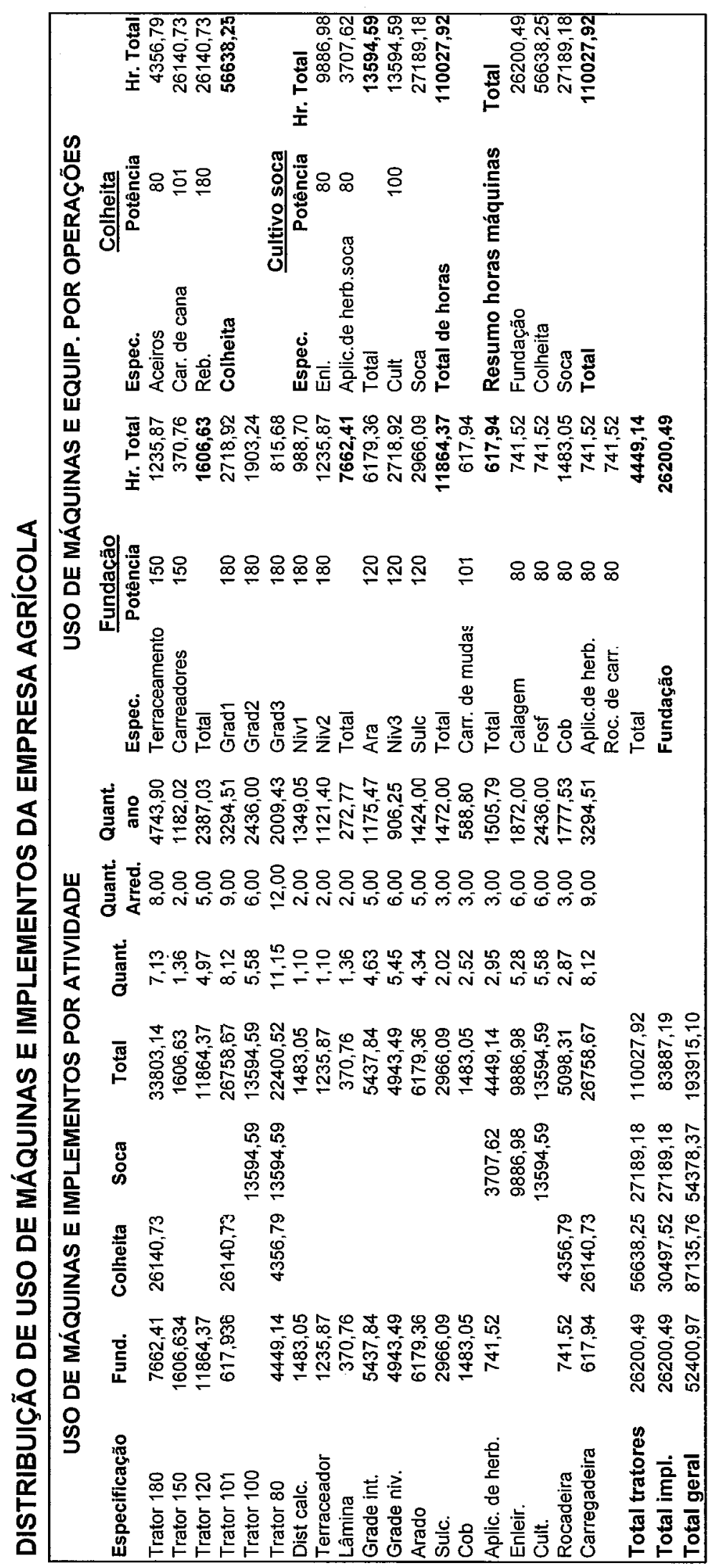




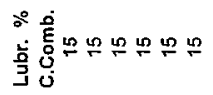

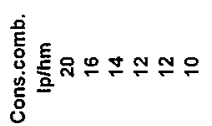

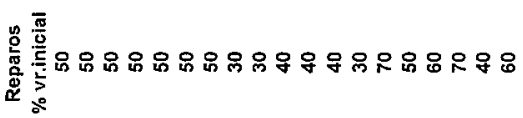

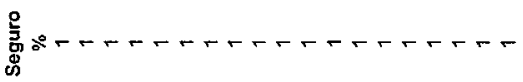

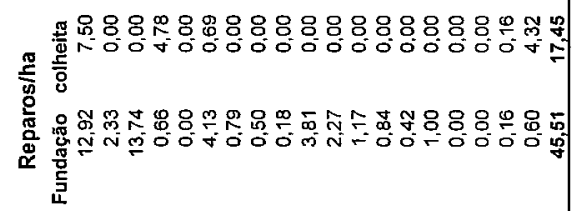

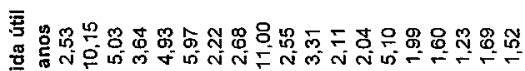

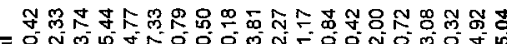
要转

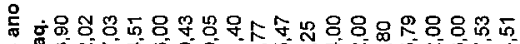

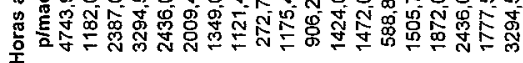

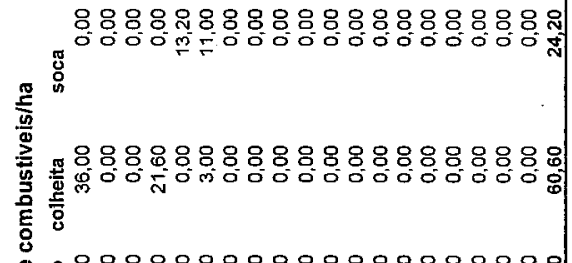

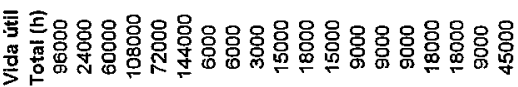

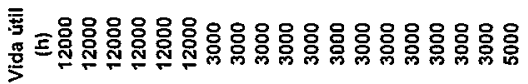

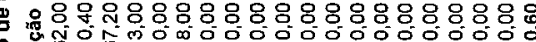

政

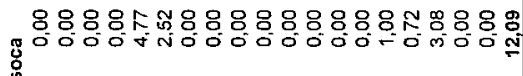

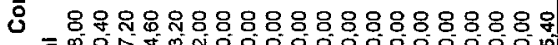

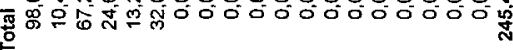

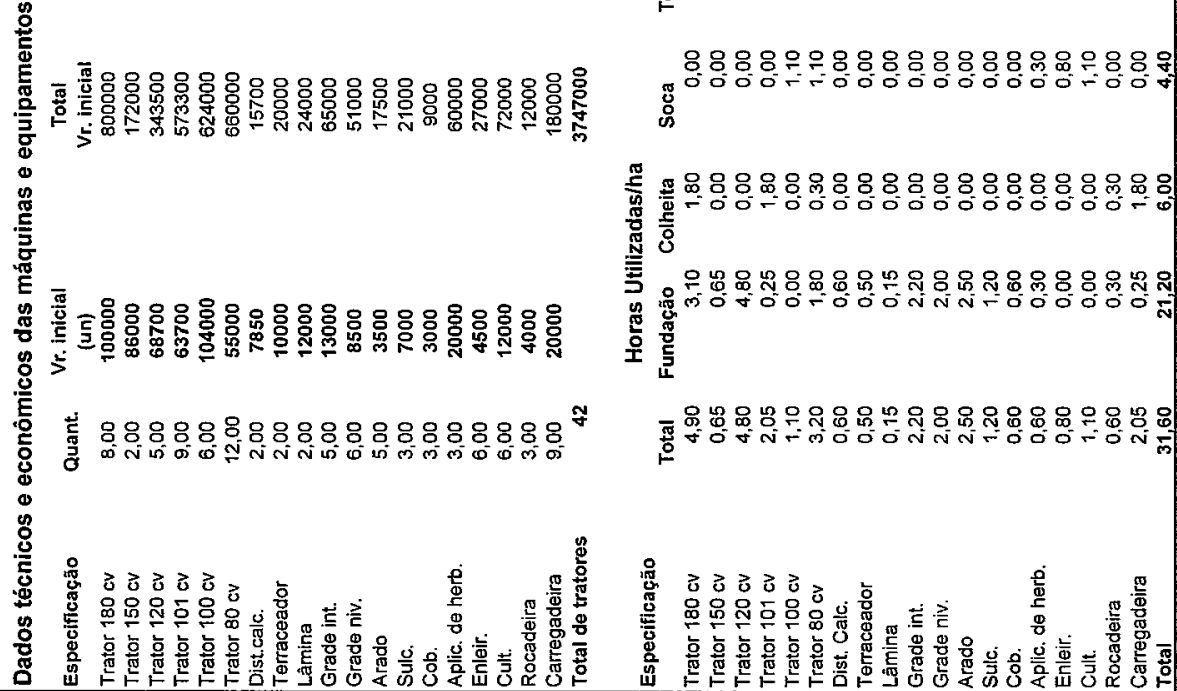




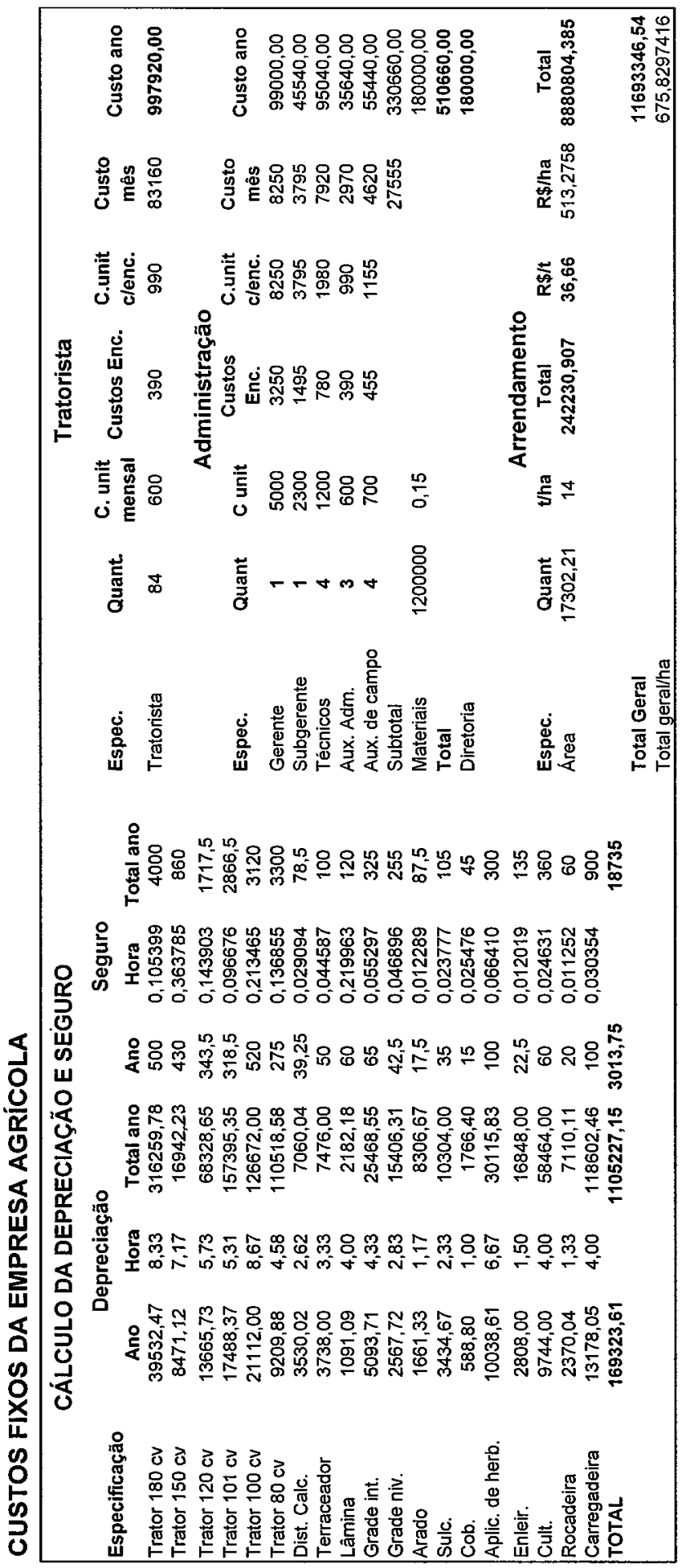




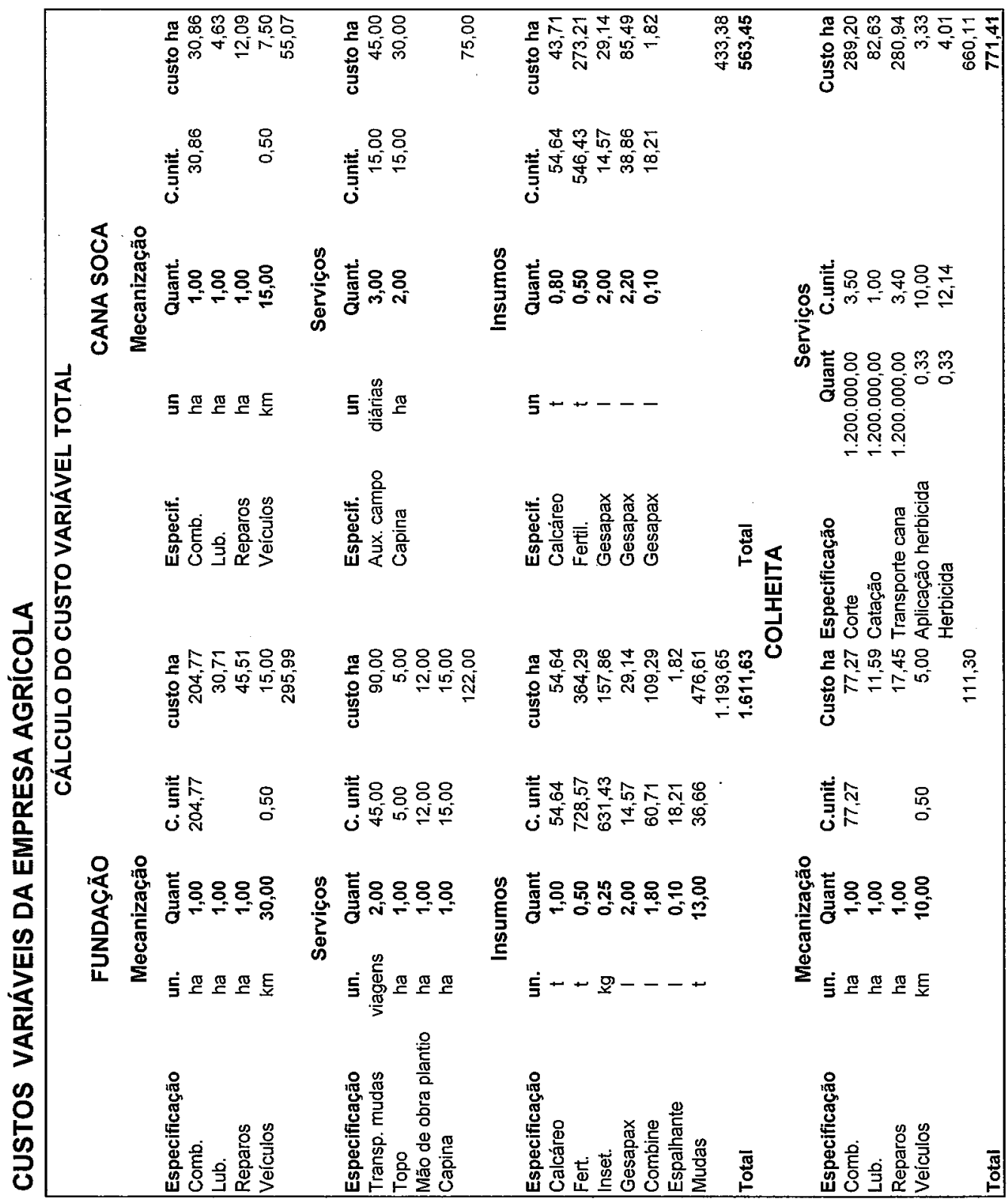




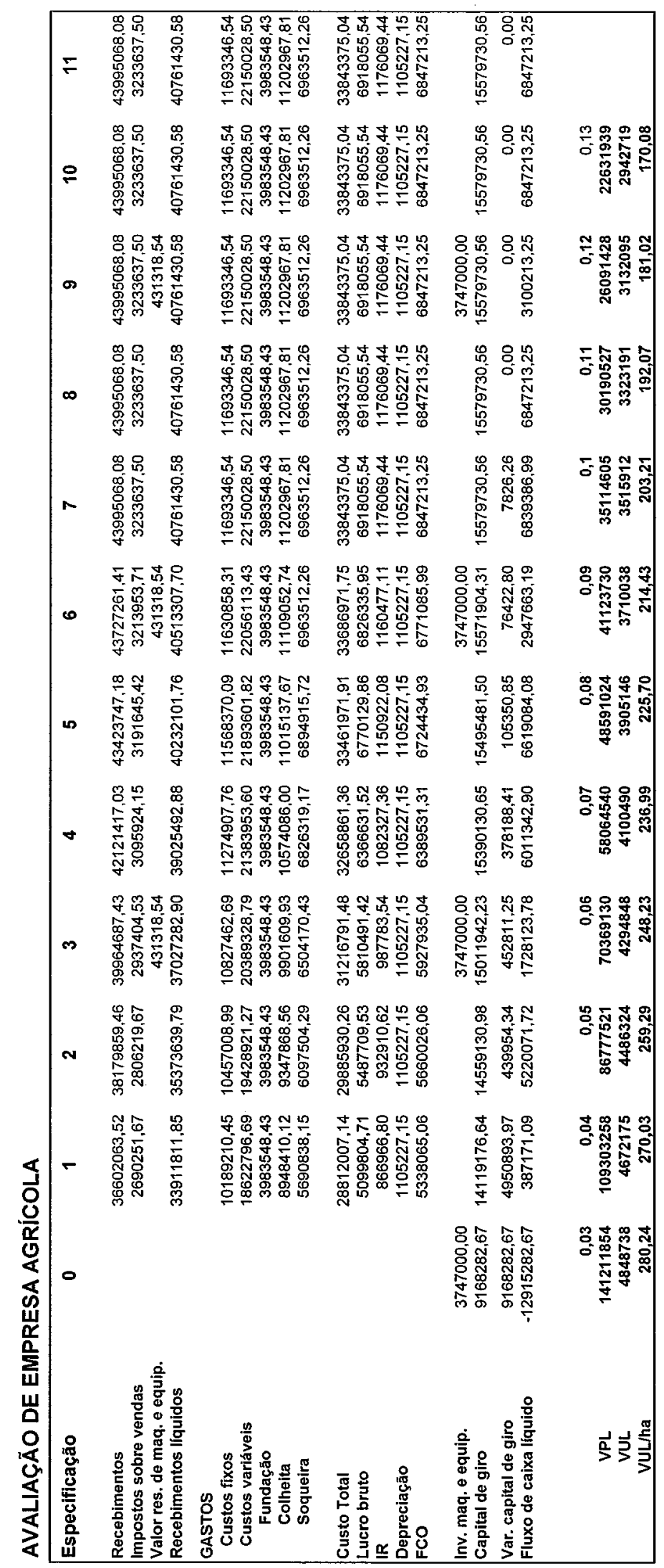




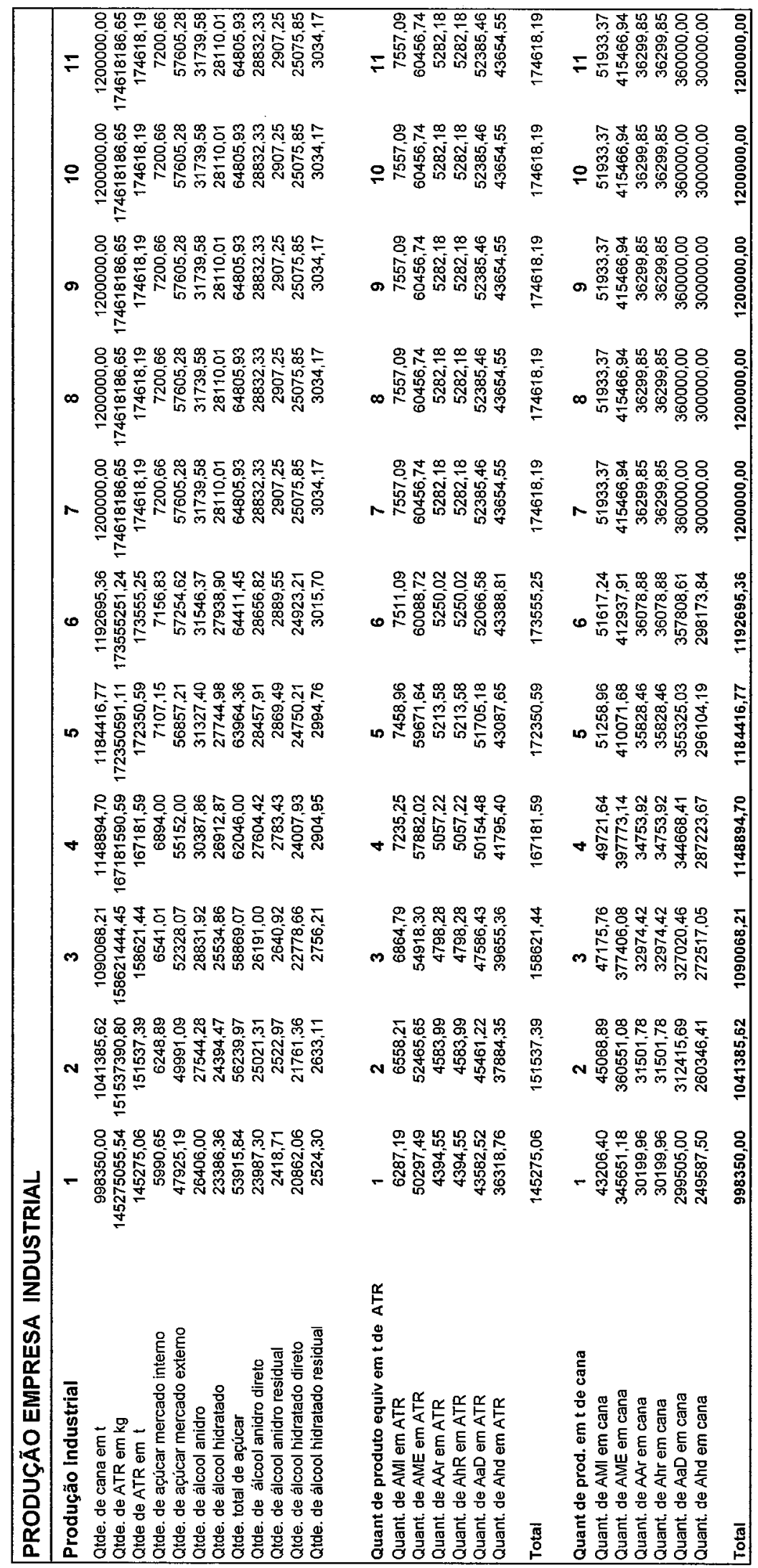




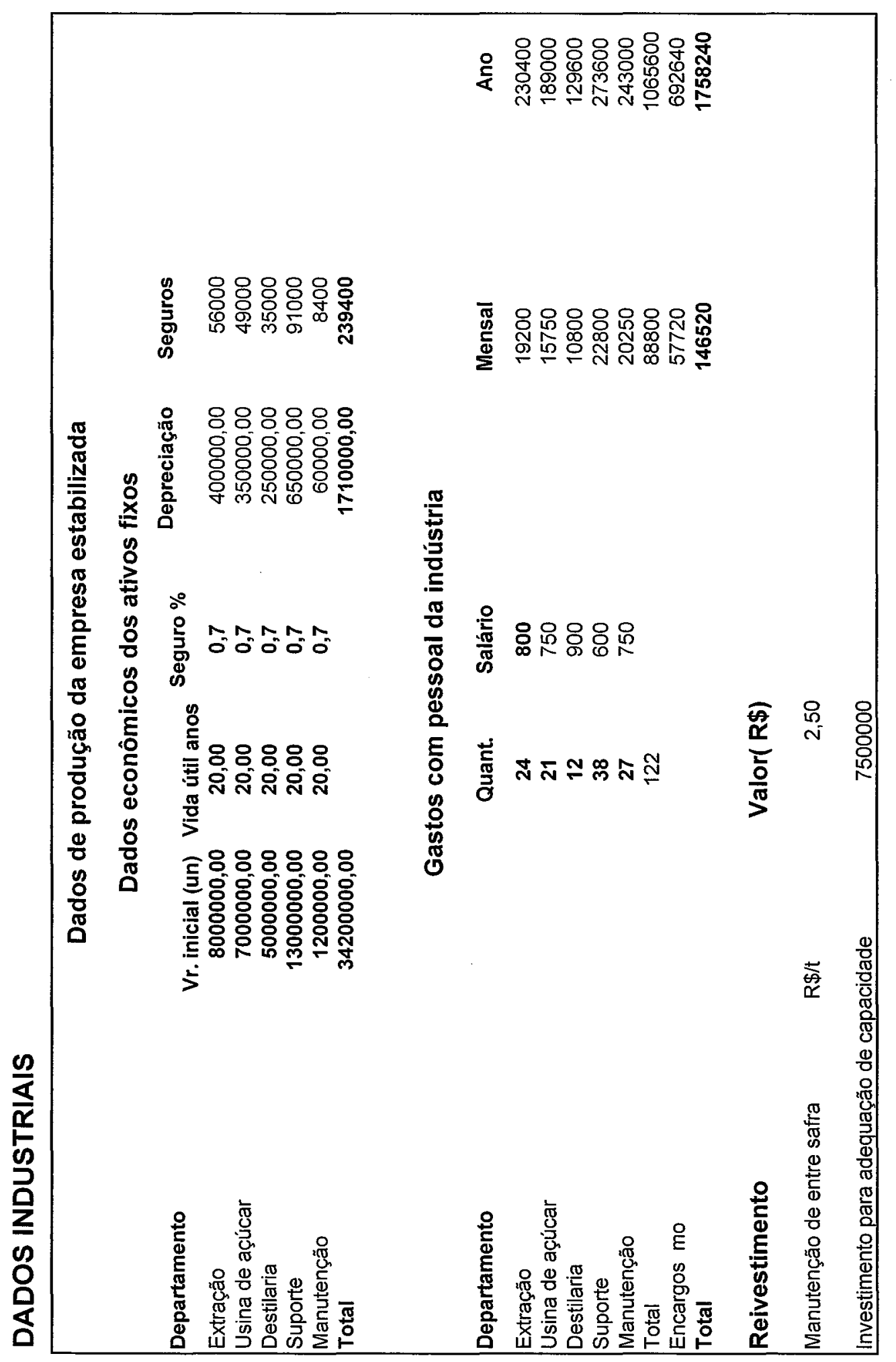




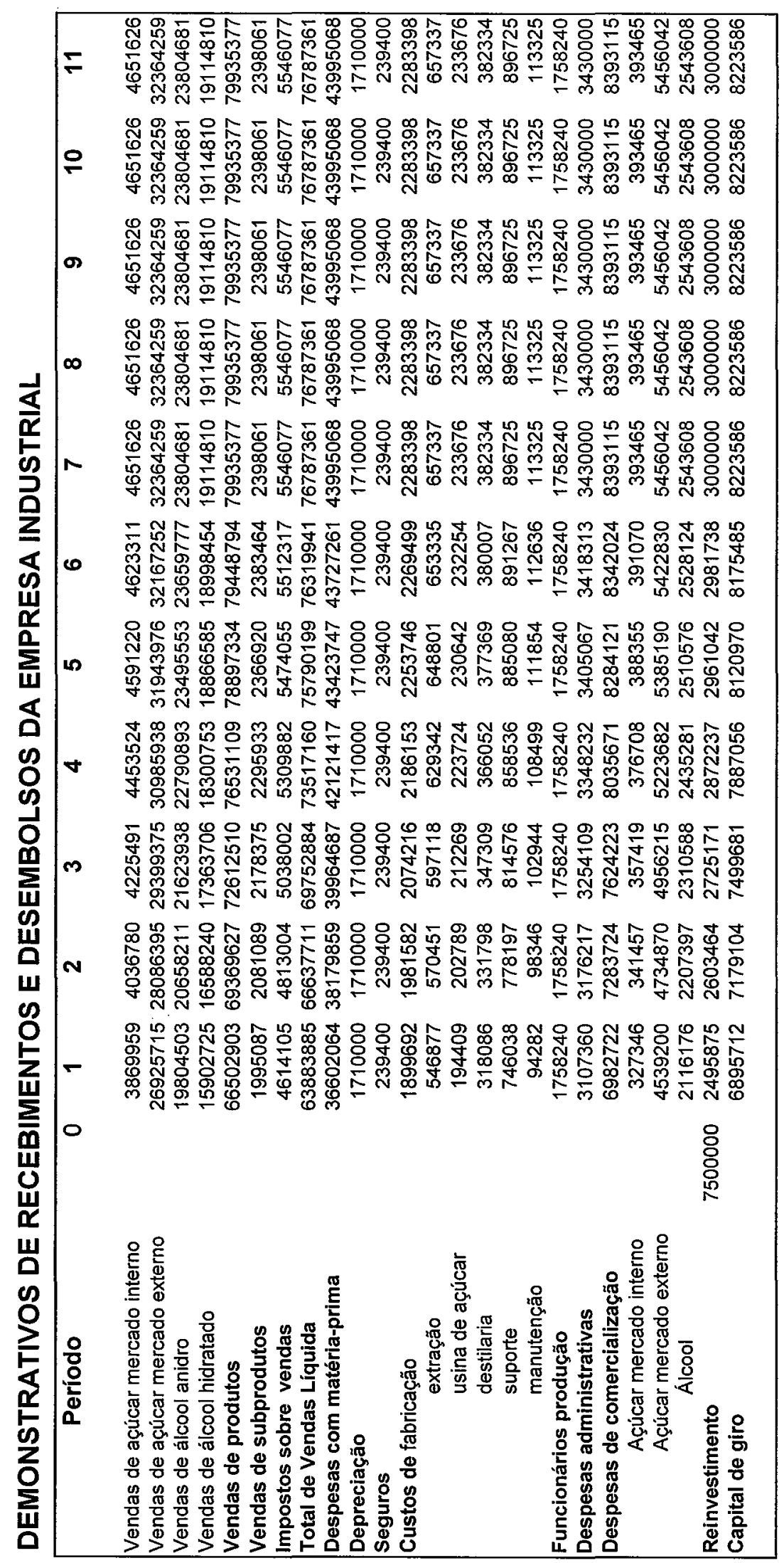




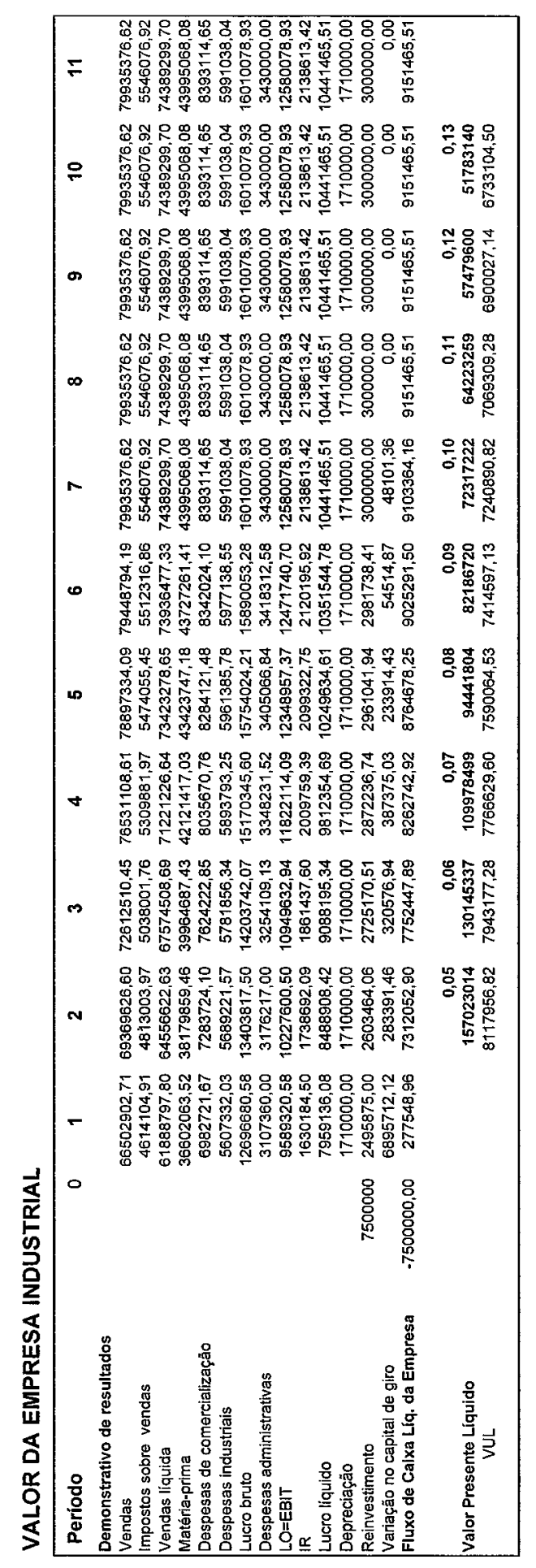




\section{REFERÊNCIAS BIBLIOGRÁFICAS}

AGENCIA NACIONAL DO PETRÓLEO - ANP. Dados estatísticos. http://www.anp.gov.br (08 jun. 2002)

AZEVEDO FILHO, A.J.B. Elementos da matemática financeira e análise de projetos de investimento. http://www.am.esalq.usp.br/matfin.html (01 jun. 2001)

ASSOCIAÇÃO DOS PRODUTORES DE ÁLCOOL E AÇÚCAR DO ESTADO DO PARANÁ - ALCOPAR. Estatísticas. http://www.alcopar.org.br (15 out. 2002)

BENNINGA, S.Z.; SARIG, O.H. Corporate finance: a valuation approach. New York: McGraw-Hill Companies, 1997. 445p.

BUSSEY, L.E. The economic analysis of industrial projects. New York: Prentice-Hall, 1999. 491p. (International Series In Industrial and Systems Engineering)

CENTRO DE ESTUDOS AVANÇADOS EM ECONOMIA APLICADA - CEPEA. Indicadores de preços. http://www.cepea.esalq.usp.br (30 out. 2002) 
ClEMENTE, A.; SOUZA, A. Projetos empresariais e públicos. 1.ed. São Paulo: Atlas, 1999. 341p.

CONCENTRAÇÃO na venda de açúcar e álcool. Gazeta Mercantil, São Paulo, 08 dez. 2001. p.12.

CONSELHO DOS PRODUTORES DE CANA-DE-AÇÚCAR, ACÚCAR E ÁlCOOL DO ESTADO DE SÃO PAULO - CONSECANA. Circular 10/02 30/09/2002. http://www.udop.com.br (10 out. 2002a)

CONSELHO DOS PRODUTORES DE CANA-DE-AÇÚCAR, AÇÚCAR E ÁlCOOL DO ESTADO DE SÃO PAULO - CONSECANA. Manual de instruções. 3.ed. Piracicaba: CONSECANA, 2002b. 117p.

COSTA, C.C. da. Formação de preços de açúcar e álcool combustível anidro e hidratado no estado de São Paulo. Piracicaba, 2000. 104p. Tese (Mestrado) - Escola Superior de Agricultura "Luiz de Queiroz", Universidade de São Paulo.

COPELAND, T.; KOLLER, T.; MURRIN, J. Avaliação de empresas "valuation": calculando e gerenciando o valor das empresas. São Paulo: Makron, 2000. 521p.

DAMODARAN, A. Avaliação de investimentos. 3.ed. Rio de Janeiro: Qualitymark, 2001.628p.

FALCINI, P. Avaliação econômica de empresas: técnica e prática. 2.ed. São Paulo: Atlas, 1995. 205p. 
FERNANDES, A.C. Cálculos na agroindustria da cana-de-açúcar. 1.ed. Piracicaba: Sociedade dos Técnicos Açucareiros e Alcooleiros do Brasil STAB, 2000. 193p.

FNP CONSULTORIA \& COMÉRCIO. Agrianual 2000: anuário da agricultura brasileira. São Paulo, 2000. p.249-273: cana-de-açúcar.

FNP CONSULTORIA \& COMÉRCIO. Agrianual 2001: anuário da agricultura brasileira. São Paulo, 2001. p.248-265: cana-de-açúcar.

GALESNE, A.; FENSTERSEIFER, J.E.; LAMB, R. Decisões de investimentos da empresa. São Paulo: Atlas, 1999. 295p.

GUILHOTO, J.J.M.; FURTOSO, M.C.O.; BARROS, G.S.C. O agronegócio na economia brasileira - 1994-99. http//www.cna.org.br (12 set. 2000)

GUJARATI, D.N. Econometria básica. 3.ed. São Paulo: Makron Books, 2000. $846 \mathrm{p}$.

HOLANDA, N. Planejamento e projetos. Rio de Janeiro: APEC, 1974. 402p.

LAPPONI, J.C. Avaliação de projetos. 1.ed. São Paulo: LTE, 1996. 264p.

LÓPEZ, L.F. O que está acontecendo no processo de fusões e aquisições no setor sucroalcooleiro no Brasil ? http://www.canaweb.com.br/ Conteudo/Secaotecnica/Administracao08.htm (20 jun. 2002) 
MARJOTTA-MAISTRO, M.C. Ajustes nos mercados de álcool e gasolina no processo de desregulamentação. Piracicaba, 2002. 171p. Tese (Doutorado) - Escola Superior de Agricultura “Luiz de Queiroz”, Universidade de São Paulo.

MARQUES, P.V. Noções básicas de concentração de mercados. 2.ed. Piracicaba: ESALQ, Depto. Economia, Administração e Sociologia, 1992. 11p. (Série Didática, 82)

MARTINS, E. Avaliação de empresas: da mensuração contábil à econômica. Caderno de Estudos - FIPECAFI, v.13, n.24, p.28-37, jul./dez. 2000.

MARTINS, E. Avaliação de empresas: da mensuração contábil à econômica. 1.ed. São Paulo: Atlas, 2001. 414p.

MATOS, J.A. de. Capital structure: models and ideas. /Apresentado ao 1. Encontro Brasileiro de Finanças, São Paulo, 2001/

MILLAN, P.S. Emissão de debêntures, mudança de estrutura de capital e valor da empresa. São Paulo, 1992. 171p. Tese (Mestrado) - Faculdade de Economia e Administração Universidade de São Paulo.

MORAES, M.A.F.D. A desregulamentação do setor sucroalcooleiro do Brasil. Americana: Caminho Editorial, 2000. 238p.

NORONHA, J.F. Projetos agropecuários: administração financeira, orçamentação e avaliação econômica. Piracicaba: FEALQ, 1981. 269p. 
PASIN, R.M.; NEVES, M.F. Fusões, aquisições e internaciolnalização: o caso da agroindústria sucro-alcooleira. http://www.canaweb.com.br /Conteudo/Secaotecnica/Administracao06.htm (20 jun. 2002)

SOUZA, Z.J. de; BURNQUIST, H.L. A comercialização da energia elétrica co-gerada pelo setor sucroalcooleiro. São Paulo: Plêiade, 2000. 150p.

UNIÃO DAS DESTILARIAS DO OESTE PAULISTA - UDOP. Cana on-line: estatísticas. http://www.udop.com.br (08 jun. 2002)

VIEIRA, M.C. Avaliação econômica de micro e mini usinas de leite - DIRA de Marilia. Piracicaba, 1998. 244p. Tese (Mestrado) - Escola Superior de Agricultura "Luiz de Queiroz", Universidade de São Paulo. 